\title{
Contribution to the diversity of the
} fossil record of turtles (Testudinata) from Chubut Province (Argentina) and its significance in understanding the evolution of turtles in Southern South America

\author{
JULIANA STERLI, ${ }^{\mathbf{1}, 2}$ \\ EVANGELOS VLACHOS $\mathbf{1 , 2}$ \\ MARCELO KRAUSE ${ }^{\mathbf{1}-\mathbf{3}}$ \\ PABLO PUERTA ${ }^{2}$ \\ CAROLINA ORIOZABALA ${ }^{\mathbf{1 , 2}}$
}

1. CONICET, Consejo Nacional de Investigaciones Científicas y Técnicas, Argentina.

2. Museo Paleontológico Egidio Feruglio. Av. Fontana 140, 9100 Trelew, Chubut, Argentina.

3. Universidad Nacional de Río Negro. Av. Roca 1242, 8332 General Roca, Río Negro, Argentina.

Recibido: : 16 de septiembre 2020 - Aceptado: 26 de febrero 2021 - Publicado: 25 de junio 2021

Para citar este artículo: Juliana Sterli, Evangelos Vlachos, Marcelo Krause, Pablo Puerta, \& Carolina Oriozabala (2021). Contribution to the diversity of the fossil record of turtles (Testudinata) from Chubut Province (Argentina) and its significance in understanding the evolution of turtles in Southern South America. Publicación Electrónica de la Asociación Paleontológica Argentina 21 (1): 118-160.

Link a este artículo: http://dx.doi.org/10.5710/PEAPA.26.02.2021.338

()2021 Sterli, Vlachos, Krause, Puerta, Oriozabala

Acceso Abierto Open Access

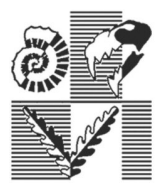

ISSN $2469-0228$
Asociación Paleontológica Argentina

Maipú $6451^{\circ}$ piso, C1006ACG, Buenos Aires

República Argentina

Tel/Fax (54-11) 4326-7563

Web: www.apaleontologica.org.ar
This work is licensed under

CC BY-NC 4.0

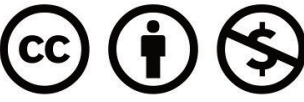




\title{
CONTRIBUTION TO THE DIVERSITY OF THE FOSSIL RECORD OF TURTLES (TESTUDINATA) FROM CHUBUT PROVINCE (ARGENTINA) AND ITS SIGNIFICANCE IN UNDERSTANDING THE EVOLUTION OF TURTLES IN SOUTHERN SOUTH AMERICA
}

\author{
JULIANA STERLI 1,2, EVANGELOS VLACHOS ${ }^{1,2}$, MARCELO KRAUSE ${ }^{1-3}$, PABLO PUERTA2 ${ }^{2}$ AND CAROLINA ORIOZABALA ${ }^{1,2}$ \\ ${ }^{1}$ CONICET, Consejo Nacional de Investigaciones Científicas y Técnicas, Argentina. \\ 2Museo Paleontológico Egidio Feruglio. Av. Fontana 140, 9100 Trelew, Chubut, Argentina.jsterli@mef.org.ar, evlacho@mef.org.ar, mkrause@mef.org.ar, ppuerta@mef.org.ar, \\ coriozabala@mef.org.ar \\ 3Universidad Nacional de Río Negro. Av. Roca 1242, 8332 General Roca, Río Negro, Argentina.
}

JS: https://orcid.org/0000-0003-2942-5558; EV: https://orcid.org/0000-0002-1980-7109; MK: https://orcid.org/0000-0002-2166-2455;

\begin{abstract}
In this work we focus on the fossil record of turtles and tortoises from the Chubut Province, in Patagonia, Argentina. This record is the richest, most diverse, the longest and continuous in the country and one of the most important in the continent. In this work, we present and study new fossils from all known clades of turtles from the province, coming from targeted field campaigns, as well as from past investigations, placed in a comprehensive and detailed chronostratigraphic context. In Chubut, more than 241 occurrences of turtles from at least 223 collection points are known, spanning from the Toarcian (Jurassic) to the Tortonian (Miocene). We manage to fill some of the gaps in the fossil record, complete the anatomical knowledge of many taxa, explore new geographical areas, and present some important highlights. Among these, the record of the oldest pan-chelid turtles indicates the significant potential of the sedimentary deposits of Chubut. Furthermore, we discuss the changes in the diversity and faunal turnovers of the various turtle clades in this region during the last 180 Ma and across important events during the Cretaceous/Paleocene and Oligocene/Miocene boundaries.
\end{abstract}

Key words. Meiolaniformes. Testudines. Pleurodira. Cryptodira. Chelidae. Testudinidae. Dermochelyidae.

Resumen. CONTRIBUCIÓN A LA DIVERSIDAD DEL REGISTRO FÓSIL DE TORTUGAS (TESTUDINATA) DE LA PROVINCIA DE CHUBUT (ARGENTINA) Y SU SIGNIFICADO EN LA COMPRENSIÓN DE LA EVOLUCIÓN DE LAS TORTUGAS EN EL SUR DE SUDAMÉRICA. En este trabajo nos enfocamos en el registro fósil de tortugas de la provincia del Chubut, en la Patagonia, Argentina. Este registro es el más rico, diverso, extenso y continuo del país y uno de los más importantes del continente. En este trabajo, presentamos y estudiamos nuevos fósiles de todos los clados conocidos de tortugas de la provincia, provenientes de campañas de campo focalizadas, así como también de investigaciones pasadas, ubicados en un contexto cronoestratigráfico completo y detallado. En Chubut, ahora se conocen más de 241 ocurrencias de tortugas de al menos 223 puntos de colecta, que abarcan desde el Toarciano (Jurásico) hasta el Tortoniano (Mioceno). Logramos llenar algunos de los vacíos en el registro fósil, completar el conocimiento anatómico de muchos taxones, explorar nuevas áreas geográficas y presentar algunos aspectos destacados importantes. Entre estos, el registro de las tortugas panquélidas más antiguas indica el importante potencial de los depósitos sedimentarios de Chubut. Asimismo, discutimos los cambios en la diversidad y cambios faunísticos de los distintos clados de tortugas en esta región durante los últimos 180 Ma y en eventos importantes durante los límites del Cretácico/Paleoceno y Oligoceno/Mioceno.

Palabras clave. Meiolaniformes. Testudines. Pleurodira. Cryptodira. Chelidae. Testudinidae. Dermochelyidae.

IN A RECENTLY PUBLISHED WORK (Vlachos et al., 2018) some of us analysed the changes in the diversity of turtles in South America, and the effect of the Cretaceous/Palaeogene $(\mathrm{K} / \mathrm{Pg}$ ) extinction. One of the interesting side outcomes of the analysis was that most of the occurrences from South America are concentrated in Argentina. In this contribution we focus on the Argentinean fossil record of turtles and in particular in that of the Chubut Province, in Patagonia.

The fossil record of turtles (clade: Testudinata) in Argentina comprises at least 268 published occurrences (i.e., without counting the new information presented herein), spanning from the Late Triassic to the Pleistocene (Paleobiology Database, PBDB, accessed November $5^{\text {th }}$, 2019; Fig. 1.1-1.2). From a geopolitical point of view, fossil 
turtles have been found in most of the Argentine provinces (excluding Formosa, Chaco, Misiones, San Luis, and Tierra del Fuego). Patagonia hosts collectively the majority of the occurrences, tallying up to $171(63.8 \%)$ occurrences: 107 (39.9\%) in Chubut, 32 (11.9\%) in Río Negro, 30 (11.2\%) in Neuquén, and two (0.7\%) occurrences in Santa Cruz (Fig. 1.1-1.2).

From a temporal point of view (Fig. 1.3), the early fossil record of Argentine turtles is restricted to few provinces: San Juan and La Rioja in the Late Triassic, and Chubut, Río Negro, Neuquén, and Mendoza in the Jurassic-Early Cretaceous. The fossil record of the Late Cretaceous is the richest in Argentina (81 occurrences). After the Late Cretaceous the number of occurrences drops until the Miocene, which contains the most widely distributed fossil record in 15 different provinces. In the Plio-Pleistocene the number of occurrences drops again. No fossil turtles are known in the Plio-Pleistocene of Patagonia.

In this paper we follow the rationale of the PBDB: occurrences of turtles are recorded in 'collection' points, defined as 'any set of fossils whose exact geographic and stratigraphic position and date of collection cannot be distinguished, regardless of when they were described, and by whom' (https://paleobiodb.org/public/tips/tips.html). In this sense, some of the oldest publications definitely use the term 'locality' as comprising several collection points, which are herein distinguished as separate 'collection' points and occurrences. For example, the term 'locality' is employed for the general, broader, several square kilometer area, whereas each 'collection' point refers to each GPS point (Fig. 2 ). We corrected in the PBDB the various occurrences of Chelonoidis gringorum from the northwestern (NW) Chubut area (Oriozabala et al., 2018). Originally, these occurrences were grouped into four 'localities' sensu lato: Río Chico, Aguada Escondida, Cerro Zeballos, and Paso del Sapo; thus, counting only four occurrences of that taxon (Oriozabala et al., 2018). However, we have updated this information, which actually refers to at least 29 occurrences of that tortoise (Fig. 2). Of course, this approach will tend to inflate more recent published data compared to the older ones, but this is the best approach to properly estimate the alpha diversity of turtles. A comprehensive list of the collection
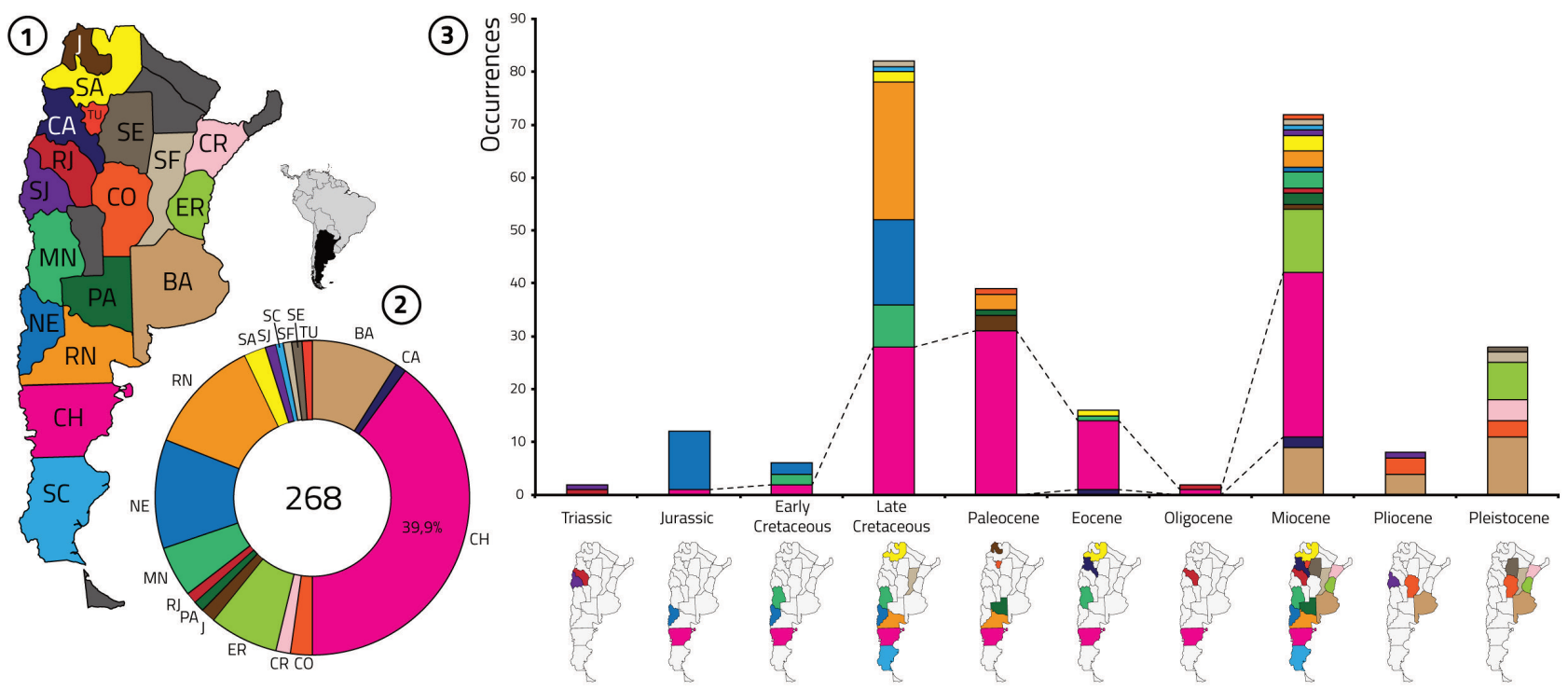

Figure 1. The Argentinean fossil record of turtles per province and through time. 1, Map of Argentina showing the provinces with fossil turtles. 2, Pie diagram showing the percentage of the occurrences per Argentinian province, note that Chubut has almost $40 \%$ of the occurrences in the country. 3, Diagram showing the occurrences of extinct turtles through time. BA, Buenos Aires; CA, Catamarca; CH, Chubut; CO, Córdoba; CR, Corrientes; ER, Entre Ríos; J, Jujuy; MN, Mendoza; NE, Neuquén; PA, La Pampa; RJ, La Rioja; RN, Río Negro; SA, Salta; SC, Santa Cruz; SE, Santiago del Estero; SF, Santa Fe; SJ, San Juan; TU, Tucumán. 
point and relevant chronostratigraphic and taxonomic information is presented in the Supplementary Information.

This summarized outline clearly indicates that the fossil record of turtles from Chubut is perhaps the most important in Argentina for several reasons: (1) it is the richest; (2) it is the most diverse; (3) it shows the longest, undisrupted, temporal extension, from the Jurassic to the Miocene. De Broin and de la Fuente (1993) recognized 15 localities with fossil remains of turtles in Chubut (see de Broin \& de la Fuente 1993, fig. 1). Until the present paper, more than 107 different collections of turtles have been published. We report herein at least 116 new collection points with fossil turtles, summing up to 223 different collection points in the Chubut Province. From the 48 species known in the fossil turtle record of Argentina, Chubut is home to 14 of them: the stem turtle Condorchelys antiqua, the meiolaniformes Chubutemys copelloi, Patagoniaemys gasparinae, and Peligrochelys walshae, the meiolaniids Gaffneylania auricularis and Niolamia argentina, the pan-chelids Bonapartemys bajobarrealis, Hydromedusa casamayorensis, Prochelidella argentinae, Prochelidella cerrobarcinae, Salamanchelys palaeocenica, Yaminuechelys maior, and Yaminuechelys
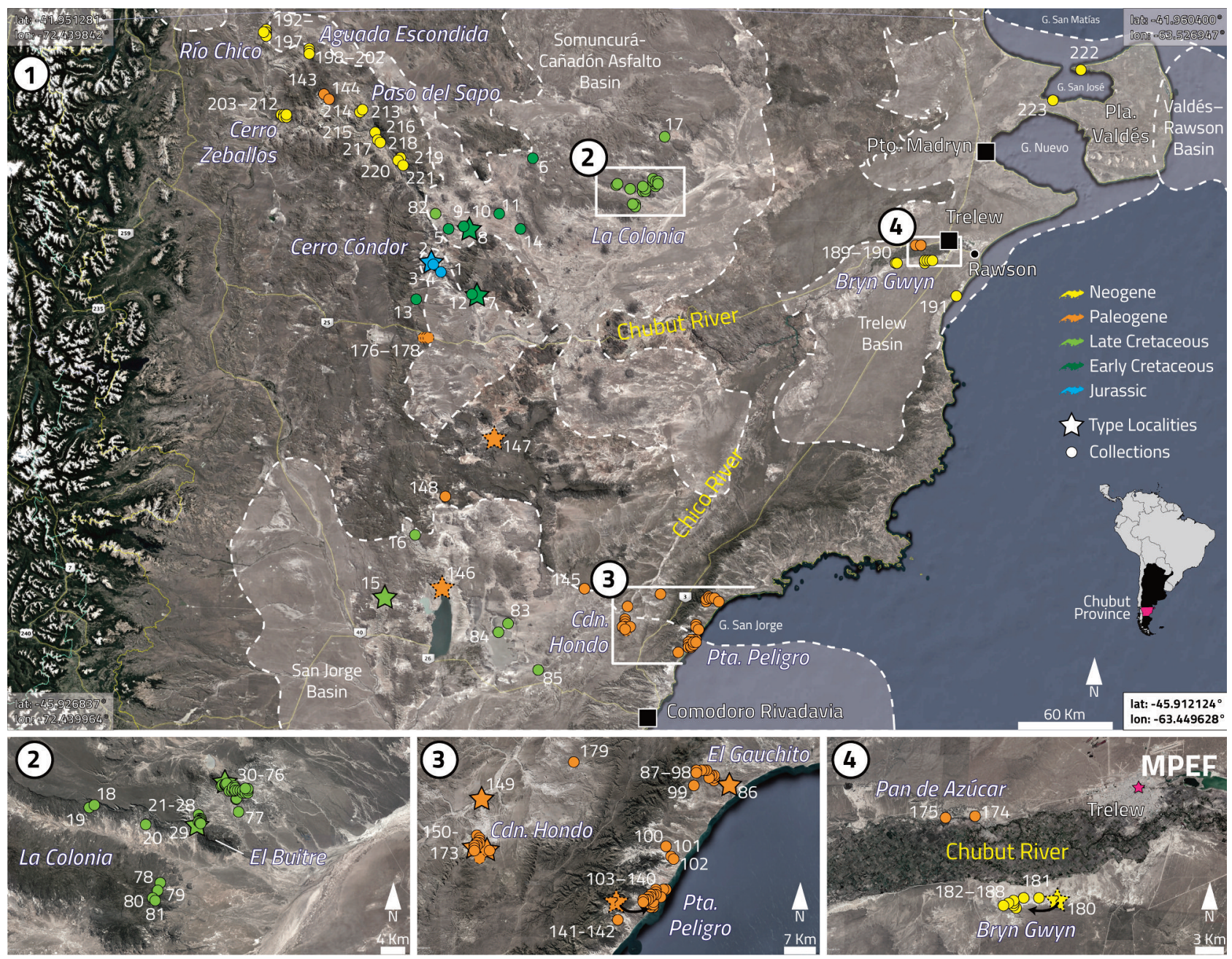

Figure 2. Map of Chubut Province with all the known collections of extinct turtles. 1, General view of Chubut Province. 2, La Colonia area. 3, Punta Peligro-El Gauchito área. 4, Bryn Gwyn area. White dashed lines indicate limits of the Soumuncurá-Cañadón Asfalto Basin (modified from Cortiñas, 1996; Figari et al., 2015); Trelew-Valdés and Rawson basins (modified from Scasso et al., 2010; Continanzia et al., 2011); and Golfo San Jorge Basin (modified from Fitzgerald et al., 1990; Figari et al., 1999). Stars refer to type localities, numbers correspond to the localities mentioned in Supplementary Information. Image ๑ 2018 Google, Landsat/Copernicus, and U.S. Dept. of State Geographer (1) or ๑ 2019 Maxar Technologies and $\odot 2019$ CNES/Airbus (2-4), data from SIO, NOAA, U.S. Navy, NGA, GEBCO (1-2); exported from ๑ Google Earth Pro. Cdn, Cañadón; G, Golfo; Pla, Peninsula; Pta, Punta; Pto, Puerto. 
sulcipeculiaris, and the testudinid Chelonoidis gringorum. Besides, at least one taxon of Dermochelyidae (not identified to the species level) was also present and a new genus and species of Pan-Chelidae, tallying up to at least 16 different turtle taxa in Chubut. For comparison, the total taxic diversity of the other most prolific provinces is half (Neuquén with eight and Río Negro with seven). Finally, even though Chubut is the only province with a long and undisrupted record spanning from the Early Jurassic to the Miocene, it lacks the oldest and youngest occurrences of turtles in Argentina.

This paper explores a series of objectives related to the fossil record of turtles in Chubut: (1) we present a detailed overview of the previously published knowledge on the Chubutean turtles; (2) we discuss the current ongoing investigations in Chubut, present new occurrences of turtles from the majority of the known clades of turtles in the province, and describe many new fossils in a comprehensive and detailed chronostratigraphic context; (3) we discuss the new composition of the turtle paleobiodiversity from Chubut based on the new information herein and provide some ideas on the future of paleontological research in the province.

Abbreviations. AMNH, American Museum of Natural History, New York, U.S.A.; CENPAT, Centro Patagónico de CONICET, Puerto Madryn, Chubut Province, Argentina; CPBA-V, Vertebrate Paleontological Collection, Universidad de Buenos Aires, Ciudad Autónoma de Buenos Aires, Argentina; MACN, Museo Argentino de Ciencias Naturales 'Bernardino Rivadavia', Ciudad Autónoma de Buenos Aires, Argentina; MACN-PV, Vertebrate Paleontological Collection, Museo Argentino de Ciencias Naturales 'Bernardino Rivadavia', Ciudad Autónoma de Buenos Aires, Argentina; MEF, Museo Paleontológico Egidio Feruglio, Trelew, Chubut Province, Argentina; MLP, Museo de La Plata, La Plata, Buenos Aires Province, Argentina; MPEF-PV, Vertebrate Paleontology Collection, Museo Paleontológico Egidio Feruglio, Trelew, Chubut Province, Argentina; MU, Monash University, Melbourne, Australia; UL, University of Louisville, Kentucky, U.S.A.; UNPSJB, Universidad Nacional de la Patagonia 'San Juan Bosco', Comodoro Rivadavia, Chubut Province, Argentina; USW, University of South Wales, Australia.

\section{GEOLOGY AND STRATIGRAPHY OF EXTINCT TURTLES OF CHUBUT}

The turtles in the Chubut Province come from the northwestern (Somuncurá-Cañadón Asfalto Basin), northeastern (Trelew-Valdés Basin) regions, and from the southcentral Golfo San Jorge Basin (Figs. 2 and 3). The taxa are distributed in rocks spanning the Early Jurassic-late Miocene interval, involving 14 formations deposited in continental (9), mixed (2), and marine (3) systems. The temporal and spatial analysis of the turtle record allows recognizing five chronostratigraphic packages, involving different lithostratigraphic units, but similar or closely-related depositional contexts. These chronostratigraphic packages are, from older to younger, the Jurassic (J), the Cretaceous (K), the uppermost Cretaceous-lowermost Paleogene (K-Pg), the Paleogene (Pg), and the Neogene (Ng) (Fig. 3).

The chronostratigraphic package $\mathrm{J}$ is represented by the Lower-Middle Jurassic Cañadón Asfalto Formation in the Cañadón Asfalto Basin. This formation is characterized by lacustrine mudstones and limestones deposited during a syn-rift stage through the mid-late Toarcian-Aalenian (?Bajocian) time (Rauhut et al., 2002; Cúneo et al., 2013a; Figari et al., 2015; Fantasia et al., 2021).

The chronostratigraphic package $\mathrm{K}$ is constituted by the upper Los Adobes (Bardas Coloradas Member) and the lower Cerro Barcino (Puesto La Paloma and Cerro Castaño members) formations in the Somuncurá-Cañadón Asfalto Basin, and by the Bajo Barreal Formation in the Golfo San Jorge Basin. In general terms, these units are characterized by alluvial sedimentation occurred during a sag phase, and subordinately affected by tectonic reactivation (e.g., Bardas Coloradas Member in Somuncurá-Cañadón Asfalto Basin and Bajo Barreal Formation in the Golfo San Jorge Basin) (e.g., Fiztgerald et al., 1990; Cortiñas, 1996; Figari et al., 1999, 2015). The Bardas Coloradas Member succession is characterized by multi-episodic fluvial channels and sandy to muddy floodplains on which lacustrine bodies developed (e.g., Chebli et al., 1976; Codignotto et al., 1978; Allard et al., 2009; Villegas et al., 2014), differing only in thickness, probably due to intrabasinal tectonic activity (Proserpio, 1987; Villegas, 2015; Figari et al., 2015). The turtle remains from Cerro Barcino Formation come from the Puesto La Paloma and Cerro Castaño members, both consisting of pyroclastic- 


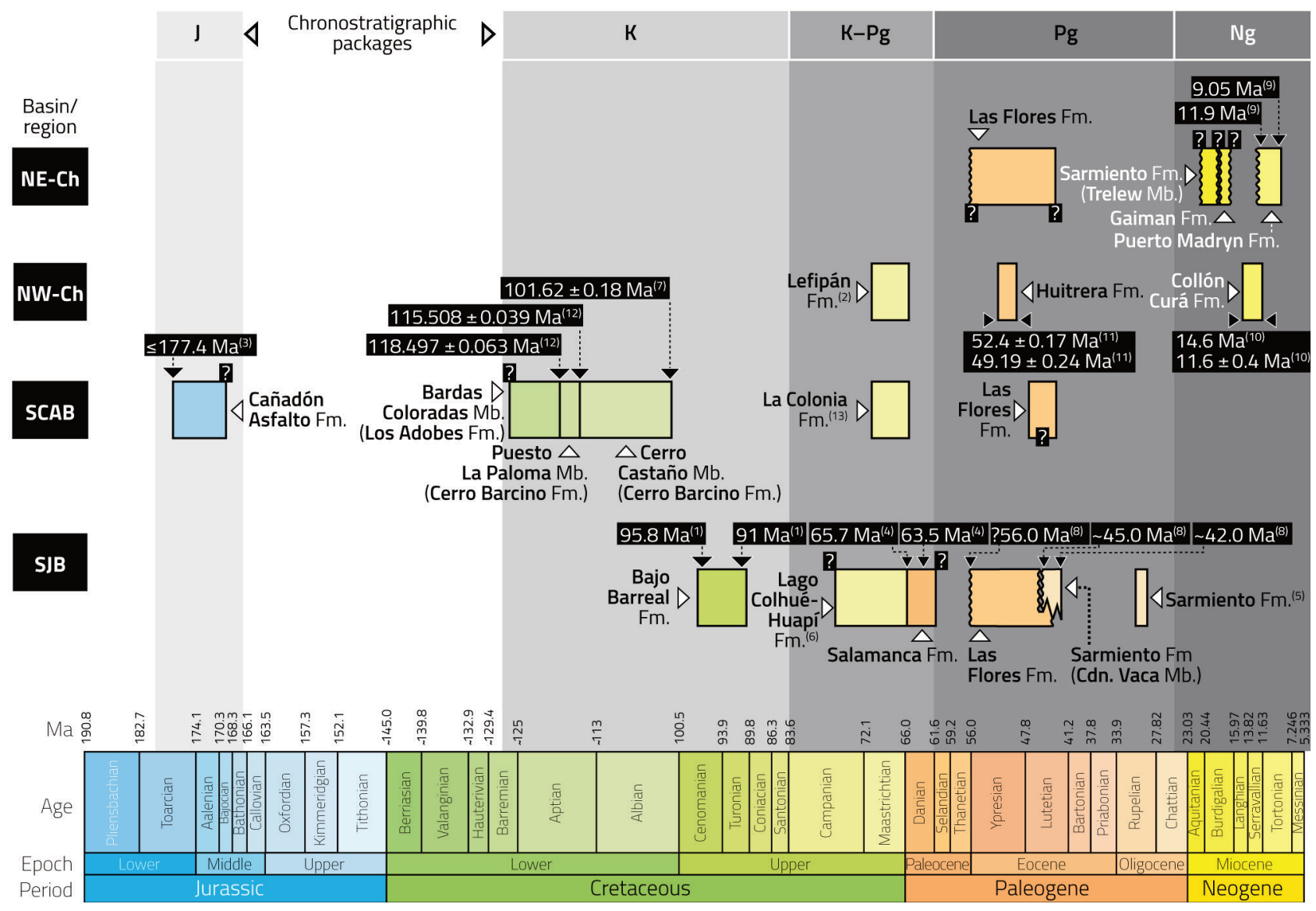

Figure 3. Chronostratigraphic scheme of units bearing turtles in Chubut Province. Colored boxes correspond to lithostratigraphic units cited in the text. They are displayed in horizontal, parallel, lines according to different region and basins, decreasing in age from left to right. Superscript numbers after numerical ages inside black boxes correspond to bibliography which provided the geochronological, numerical data. Superscript numbers after lithostratigraphic names correspond to the bibliography which provided reliable relative age estimations. Basin/regions: SJB, Golfo San Jorge Basin; NW-Ch, northwest Chubut; SCAB, Somuncurá-Cañadón Asfalto Basin; NE-Ch, northeast Chubut (including Gaiman region and Valdés Basin). Chronostratigraphic packages: J, Jurassic; K, Cretaceous; K-Pg, Cretaceous-Paleogene; Pg, Paleogene; Ng, Neogene. References: (1) Bridge et al., 2000; (2) Aberhan et al., 2007; Barreda et al., 2012; Scasso et al., 2012; Vellekoop et al., 2017; (3) Cúneo et al., 2013a; (4) Clyde et al., 2014; (5) Dozo et al., 2014; (6) Casal et al., 2015; (7) Carballido et al., 2017; (8) Krause et al., 2017; (9) del Río et al., 2001, 2018; Scasso et al., 2001; (10) Bucher et al., 2019; (11) Gosses et al., 2020; (12) Krause et al., 2020; (13) Clyde et al., 2021.

rich, alluvial successions. The taxa from the Puesto La Paloma Member inhabited ephemeral and unconfined alluvial system that interacted with aeolian dunes and dry interdune zones (de la Fuente et al., 2011; Umazano et al., 2017). Turtles from the Cerro Castaño Member developed within a fluvial scenery, characterized by a permanent, meandering fluvial system, with lacustrine facies and minor ash-fall deposits (Umazano et al., 2017). The Bajo Barreal Formation, in the Golfo San Jorge Basin, is characterized by fluvial depositional systems with minor ashfall events, deposited within endorreic basins (Sciutto, 1981; Figari et al., 1999; Umazano et al., 2008; Allard et al., 2015; Paredes et al., 2016).
The chronostratigraphic package $\mathrm{K}$ involves units deposited during the 'mid' Cretaceous. Charophytes and ostracods (Musacchio, 1995), and pollen (Marveggio \& Llorens, 2013) from the Bardas Coloradas Member, suggest a deposition during the Barremian-Albian period. The minimum age of the Bardas Coloradas Member is early Aptian (>118 $\mathrm{Ma}$ ) according to recent $\mathrm{U}-\mathrm{Pb}$ geochronology of tuffaceous beds of the Cerro Barcino Formation (Krause et al., 2020). These authors also constrained the depositions of the Puesto La Paloma and Cerro Castaño members to the Aptian and Albian respectively, with the overlying Las Plumas Member extending into the Cenomanian. Sedimentation of the Bajo Barreal Formation was constrained to the 
Cenomanian-Turonian lapse (Ar-Ar 96-91 Ma; Bridge et al., 2000).

The chronostratigraphic package $\mathrm{K}-\mathrm{Pg}$ involves latest Cretaceous to earliest Paleogene units from the Golfo San Jorge Basin (Lago Colhué Huapí and Salamanca formations) and Somuncurá-Cañadón Asfalto Basin (La Colonia and Lefipán formations). The Lago Colhué Huapí Formation is composed of high sinuosity fluvial systems, deposited under warm and humid climate (Casal et al., 2015, 2016; Vallati et al., 2020). Turtles proceed from the upper part of the unit (Casal, pers. comm.), which in the uppermost levels interfingers with the lowermost strata of the marine Salamanca Formation, giving place to plains with fresh-water ponds and coastal swamps (Casal et al., 2015, 2016; Vallati et al., 2020). Taxa from the Salamanca Formation come from outcrops of the Banco Negro Inferior (Feruglio, 1949) cropping out on the southern coastal area of Chubut Province (Fig. 2). This conspicuous bed, featured as the marker of the retreatment of the 'Salamanca sea', is composed by a medium to dark grey siltstone, deposited within lagoon and swamps settings (Feruglio, 1949; Raigemborn et al., 2010; Clyde et al., 2014; Comer et al., 2015). La Colonia Formation is composed of offshore-shoreface facies in the lowermost part, and tidal-influenced mixed settings upward, along with a trend toward fresher water environments (Pascual et al., 2000; Cúneo et al., 2013b, 2014; Gasparini et al., 2015; Navarro et al., 2008, 2012; Guler et al., 2014, 2019; Borel et al., 2016). Also, a mixed depositional system characterizes the Lefipán Formation. A multi-disciplinary study on the western area of the Cañadón Asfalto Basin (Fig. 2) interpreted the Lefipán succession as a tide-dominated, steepgradient and coarse-grained deltaic system fed by braided rivers that developed within an embayment (Scasso et al., 2012a).

The chronostratigraphic package $\mathrm{K}-\mathrm{Pg}$ is CampanianDanian. The deposition of La Colonia and Lefipán sediments, as well those from the Salamanca Formation, occurred during epeiric flooding that affected the Atlantic margin of Argentina, and other regions of South America, during the Late Cretaceous and the earliest Paleogene (e.g., Riccardi, 1988; Uliana \& Biddle, 1988; Clyde et al., 2021). The base of the Lago Colhué Huapí Formation is inferred to be ?Coniacian (Casal et al., 2015), after the age of the underlying
Bajo Barreal Formation (Turonian sensu Bridge et al., 2000), the contained dinosaur fauna, and its relationship with the dinosaur fauna from the Allen Formation. The age of the upper Lago Colhué Huapí Formation, on the other hand, is considered to be Maastrichtian in age and close to the K/Pg boundary (Vallati et al., 2020), based on the palynomorphs, mesofossils and leaves content. Such boundary was also recognized within both the Lefipán (Aberhan et al., 2007; Barreda et al., 2012; Scasso et al., 2012a; Vellekoop et al., 2017) and La Colonia (Clyde et al., 2021) formations, suggesting that these formations were almost contemporaneous (see Casal et al., 2016, p. 65 for a broader correlation with other basins). The Salamanca Formation in the southcenter area of Chubut Province was constrained, through a multi-disciplinary geochronological study, to be early to middle Danian (early Paleocene; $65.7-63.5 \mathrm{Ma}$ ) in age (Clyde et al., 2014). Nevertheless, the Banco Negro Inferior on the coastal area might be younger as suggested by the prograding nature of the upper Salamanca Formation (Clyde et al., 2014; Comer et al., 2015).

The chronostratigraphic package Pg includes Eocene to Oligocene continental units from the Golfo San Jorge Basin (Las Flores Formation and Cañadón Vaca Member; Sarmiento Formation) as well as from the northwestern and northeastern regions of Chubut Province (Figs. 2 and 3). The oldest strata within this package crop out in the southern coastal area of Chubut Province (Bajo Palangana, Cerro Redondo) (Simpson, 1935a; Feruglio, 1949), from surroundings of El Pajarito (near Paso de Indios town, see Scillato-Yané, 1977) and from Gaiman region (Simpson, 1935b), and consist of siliciclastic sandstones and mudstones assignable to the Las Flores Formation, a unit deposited in lacustrine and fluvial systems (Legarreta \& Uliana, 1994; Raigemborn et al., 2010; Krause \& Piña, 2012). The remaining records proceed from tuffaceous beds from both Huitrera and Sarmiento formations. Taxa from the Huitrera Formation, in Laguna del Hunco locality (Fig. 2), are contained within lacustrine facies deposited within a volcanic caldera (Gosses et al., 2020). Specimens from Sarmiento Formation, in this package, come from two different stratigraphic levels, the oldest restricted to the Eocene Cañadón Vaca Member, and the youngest to an Oligocene bed. The records from the Cañadón Vaca Member are those pro- 
ceeding from Cañadón Vaca and Cañadón Hondo localities (Simpson, 1935a, 1937), while the records from the Oligocene beds originate from Cabeza Blanca (Dozo et al., 2014). In both stratigraphic intervals, the sedimentation is represented by alluvial plains and loessic deposits with subordinate siliciclastic mudstones (Bellosi \& Krause, 2014; Dozo et al., 2014; Sterli et al., 2015; Maniel et al., 2018).

The lapse assigned here to the chronostratigraphic package Pg is Eocene-Oligocene. The age of the Las Flores Formation was inferred to be $\sim 56 \mathrm{Ma}$ to $42.1 \mathrm{Ma}$ (Krause et al., 2017). Particularly the middle Las Flores to the uppermost Koluel-Kaike succession in south-center Chubut was constrained to be $c a$. 51.4-42.2 Ma (mid-Ypresian-late Lutetian), with the Koluel-Kaike Formation being 46.7-42.2 Ma (Lutetian) (Woodburne et al., 2014; Krause et al., 2017). According to stratigraphic relationships, the Cañadón Vaca Member was considered partially equivalent to the upper Koluel-Kaike Formation, postulating an interval of deposition of 45-42 Ma (Krause et al., 2017). On the other hand, the Sarmiento Formation at Cabeza Blanca is about $30 \mathrm{Ma}$ (post-Tinguirirican to pre-Deseadan land mammal age), on the basis of faunal correlations with beds from ' $\mathrm{La}$ Cantera' (i.e., Gran Barranca) (Dozo et al., 2014). The portion of the Huitrera Formation containing turtles is restricted to a lacustrine setting inside the Laguna del Hunco calderalake, constrained through $\mathrm{Ar}-\mathrm{Ar}$ ages as younger than 52.54 $\pm 0.17 \mathrm{Ma}$ and older than 49.19 $\pm 0.24 \mathrm{Ma}$ (Gosses et al., 2020).

The chronostratigraphic package Ng includes continental (the Trelew member of Sarmiento and Collon Curá formations) and marine (Gaiman and Puerto Madryn formations) strata deposited during the Miocene in the northwestern and northeastern regions of Chubut Province (Figs. 2 and 3). The Trelew Member is characterized by fluvial and eolian pyroclastic successions lying above an unconformity (Simpson, 1935b; Scasso \& Bellosi, 2004). Turtles in this member proceed from a grayish tuffaceous siltstone the lowermost part, a bed containing abundant fossil mammals (Fleagle \& Bown, 1983). The Gaiman and Puerto Madryn formations are constituted by tuffs, sandstones, mudstones, and coquines, deposited within inner shelf (Gaiman and Puerto Madryn formations) to estuarine, tidal or lagoonal (Puerto Madryn Formation) systems (Scasso \& del
Río, 1987; Scasso \& Castro, 1999; Scasso \& Bellosi, 2004; Dozo et al., 2010; Scasso et al., 2012b; Cuitiño et al., 2017; Scasso \& Cuitiño, 2017). Specimens from the Gaiman Formation proceeds from a terrestrial bed in the lower section, in the transition to the underlying Sarmiento Formation (Trelew Member) (Simpson, 1942; de la Fuente \& Vucetich, 1998). Remains from the Puerto Madryn Formation are included in fine-grained deposits of inner shelf of the lower part of the unit (J. Cuitiño, pers. comm.). The Collón Curá Formation mostly comprises tuffs, tuffaceous sandstones, and calcareous beds deposited within alluvial, lacustrine, and lacustrine systems deposited in the northwestern region of the Chubut Province (e.g., Bilmes et al., 2014; Bucher et al., 2019). Taxa from this unit proceed from lacustrine of alluvial tuffaceous sandstones and mudstones from the lower and middle Collón Curá Formation (Oriozabala et al., 2018).

The chronostratigraphic package Ng involves units deposited during the Miocene. Both the Trelew Member and Gaiman Formation currently lack radiometric ages. However, the Colhuehuapian affinity of its mammal fauna helps to define a reliable age interpretation (Simpson, 1935b; Bordas, 1939; Fleagle \& Bown, 1983; Kay et al., 2008). Paleomagnetostratigraphic and geochronological studies in the Colhué Huapí Member in Gran Barranca, a unit bearing the early Miocene Colhuehuapian fauna, constrained this member to the interval of 21.11-18.62 Ma (Ré et al., 2010; Dunn et al., 2013). Moreover, adding regional considerations regarding different strata with Colhuehuapian fauna, these authors estimated that the duration of this Land Mammal Age was 1 Ma, within the interval 21.0-20.1 Ma. Interestingly, the lower boundary of the Colhué Huapí Member in Gran Barranca is marked by a regional, highly erosive unconformity (Marshall et al., 1986; Bellosi, 2010), closely related to a drop in the sea level and probably produced at about 21 Ma (Legarreta \& Uliana, 1994; Bellosi, 2010). This suggests that the unconformity at the base of the Trelew Member should be about $21 \mathrm{Ma}$ or older, pointing to an Aquitanian age for the Trelew Member. Regarding the transitional nature of the contact between the Trelew Member and the Gaiman Formation (see Simpson, 1942), the latter should be late Aquitanian-Burdigalian in age. For the Puerto Madryn Formation, a Sr-isotope chronostratigraphic analy- 
sis constrained the unit to the latest Serravalian-Tortonian interval, with a transgressive (11.9-10.4 Ma) and a regressive (10.2-9.82 Ma and 9.40-9.05 Ma) phase (del Río et al., 2001, 2018; Scasso et al., 2001). For the Lower Collón Curá Formation, $\mathrm{U}-\mathrm{Pb}$ dates of tuffaceous beds constrained its time of deposition between 14.6 and 12.8-12.7 Ma; while the upper section was accumulated between 12.8-12.7 Ma and ca. 11.6 Ma (Bucher et al., 2019).

\section{THE PAST OF CHUBUT FOSSIL TURTLES}

Historically, research on turtle fossils from Chubut has been concentrated in five localities that include numerous collections of fossils: Cerro Cóndor (Early-Middle Jurassic; Fig. 2.1), La Colonia (Late Cretaceous; Fig. 2.2), Punta Peligro (early Paleocene; Fig. 2.3), Cañadón Hondo (middle Eocene; Fig. 2.3), and Bryn Gwyn (early Miocene; Fig. 2.4).

\section{Cerro Cóndor-Turtle Town area}

Paleontological explorations in the area of Cerro Cóndor started at the end of the 1970 s by a team led by J. Bonaparte from MACN. During the 1990s a joint team from MEF and MU led by T. Rich and P. Vickers-Rich explored the area. During those fieldworks, the holotype of the meiolaniform turtle Chubutemys copelloi was found (Gaffney et al., 2007; Sterli et al., 2015). Since the early 2000s, the area has been prospected by several teams mainly led by researchers from MEF (e.g., D. Pol, J. L. Carballido), University of Louisville (G. W. Rougier), and Bayerische Staatssammlung für Paläontologie und Geologie of Munich (0. Rauhut) (Fig. 4.1, 4.2). The majority of the localities with extinct turtles from the Late Jurassic-Early Cretaceous presented in previous (e.g., Sterli, 2008; de la Fuente et al., 2011) and in this work have been discovered during field works after 2001.

\section{La Colonia}

The abelisaurid theropod Carnotaurus sastrei is the first vertebrate published from the La Colonia Formation (Bonaparte, 1985). Some years later, joint fieldworks from MEF and MLP led by R. Pascual resulted in the discovery of dipnoans, snakes, dinosaurs, turtles, plesiosaurs, birds, and mammals (e.g., Albino, 2000; Gasparini \& de la Fuente, 2000; Pascual et al., 2000; Kielan-Jaworowska et al., 2007; Sterli \& de la Fuente, 2011) (Fig. 4.3). During the early 2000s several fieldworks were conducted in the area by researchers from MEF and Louisville University (Fig. 4.4). During these fieldworks new mammalian remains were found as well as reptiles (e.g., mesungulatids, sphenodontians, snakes; Rougier et al., 2009; Lawver et al., 2011; Apesteguía et al., 2017). Since 2011, field works to the La Colonia area are more or less continuous resulting in the discovery of new specimens and new species of dinosaurs, turtles, snakes, among others (e.g., Gasparini et al., 2015; Oriozabala et al., 2020; Sterli et al., in press).

\section{Punta Peligro}

Von Huene (1928) reports the presence of turtles in the black layer of the Banco Negro (= Salamanquean) between Punta Peligro and Puerto Visser. Later, Staesche (1929) described those turtles from Punta Peligro collected by von Huene back in 1924. The area was explored afterwards by E. Feruglio (during the 1920-1930s) and later by teams led by G. G. Simpson (during the 1930s; the so-called Scarritt Expeditions), who based his studies on Feruglio's and YPF reports about the area (Simpson, 1935a, 1935b; Feruglio, 1949). The paleontological explorations in the area were reactivated at the end of the 1970s and in the 1980s by a team of the UNPSJB and by a team led by Marshall (Marshall, 1985). The team of the UNPSJB led by H. Herrera found the first mammal from Punta Peligro, Sudamerica ameghinoi described by Scillato-Yané and Pascual (1985). Between the years 1989-1990 a joint team from the MACN and the UNPSJB led by J. Bonaparte collected anurans, turtles, crocodiles, and mammals from the Punta Peligro area (Bonaparte et al., 1993). A few years later, joint teams from Argentina (MLP) and Australia (USW) led by R. Pascual (MLP) discovered numerous mammals and reptiles in the Punta Peligro area, including the first monotrema from South America, Monotrematum sudamericanum (Pascual et al., 1992). In the late 1990's expeditions led by the Museo Egidio Feruglio and the MLP recovered numerous turtle and crocodilian remains (Fig. 4.5). Expeditions organized by researchers from MEF, UL, and AMNH, were more or less continuous since 2001 (Fig. 4.6).

More than 70 years later, those turtles described by Staesche (1929) were reinterpreted by Bona and de la Fuente (2005) and Bona (2006), based on new evidence 
Pe APA | Publicación Electrónica - 2021 - Volumen 21(1): 118-160
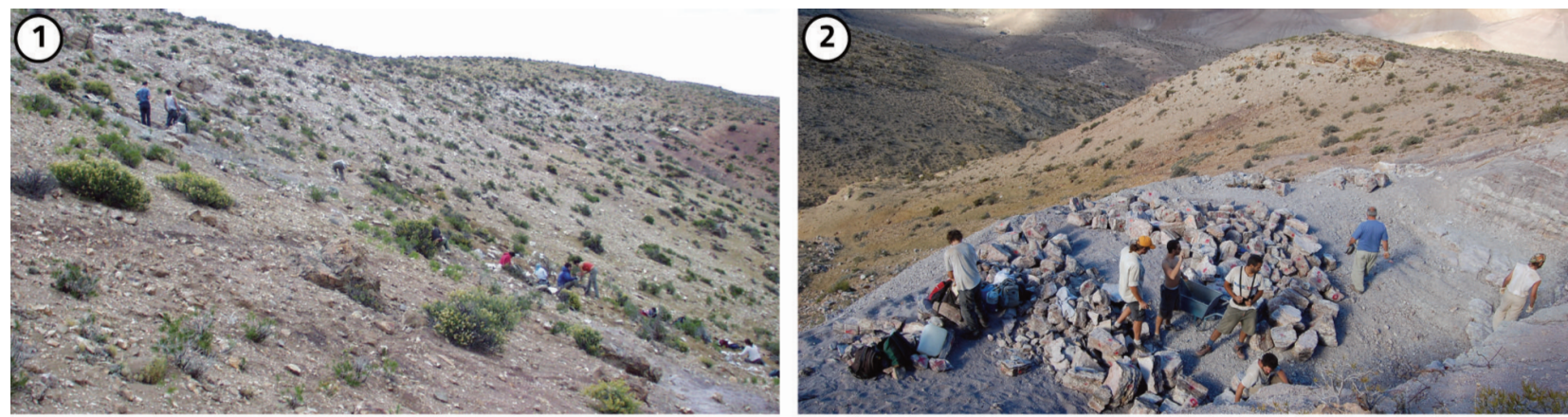

(3)

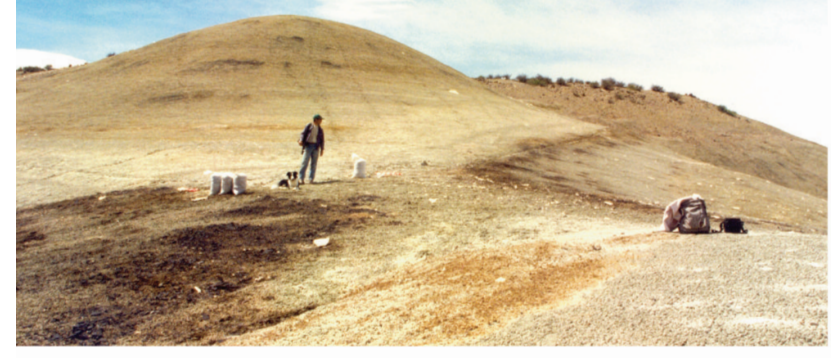

(5)
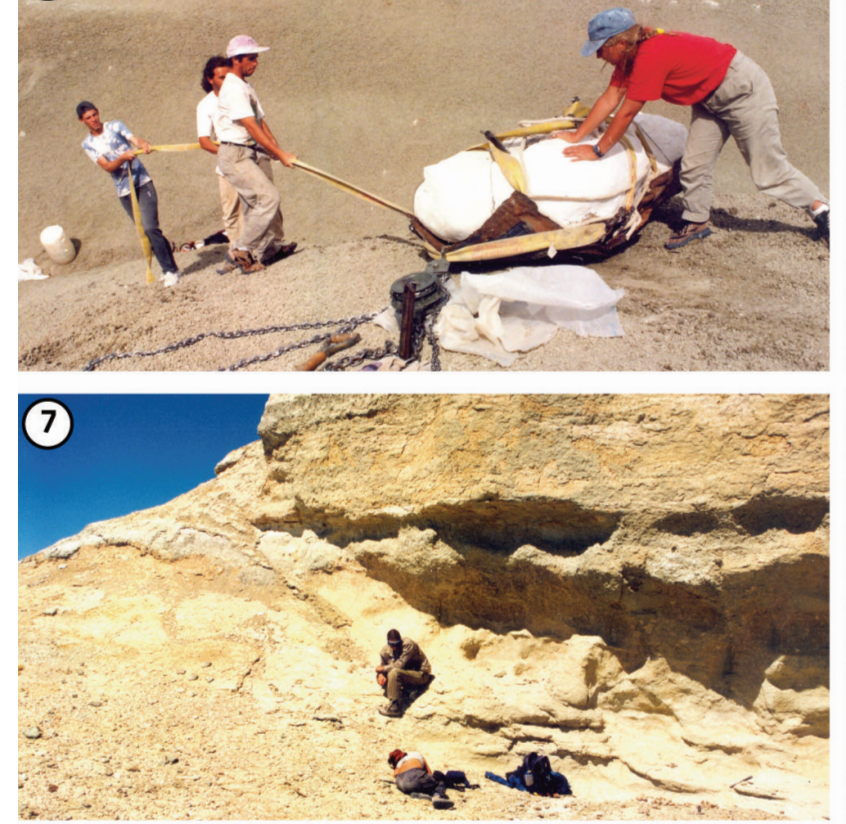

(9)

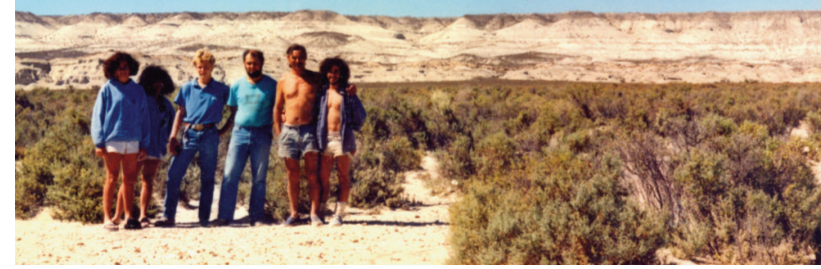

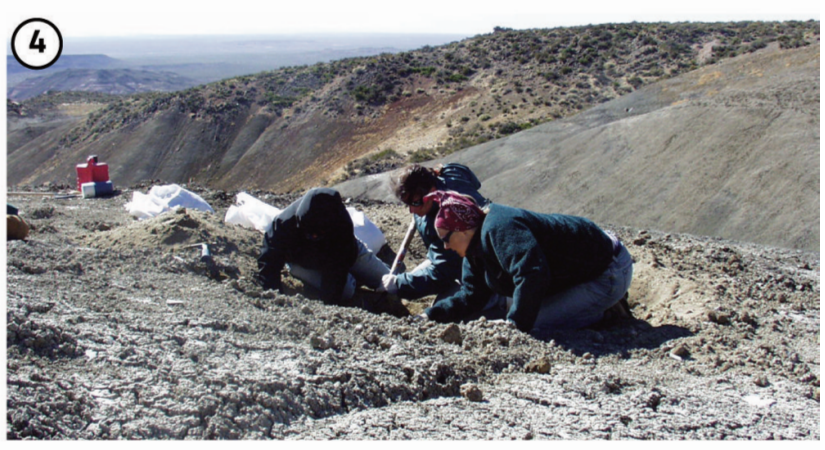
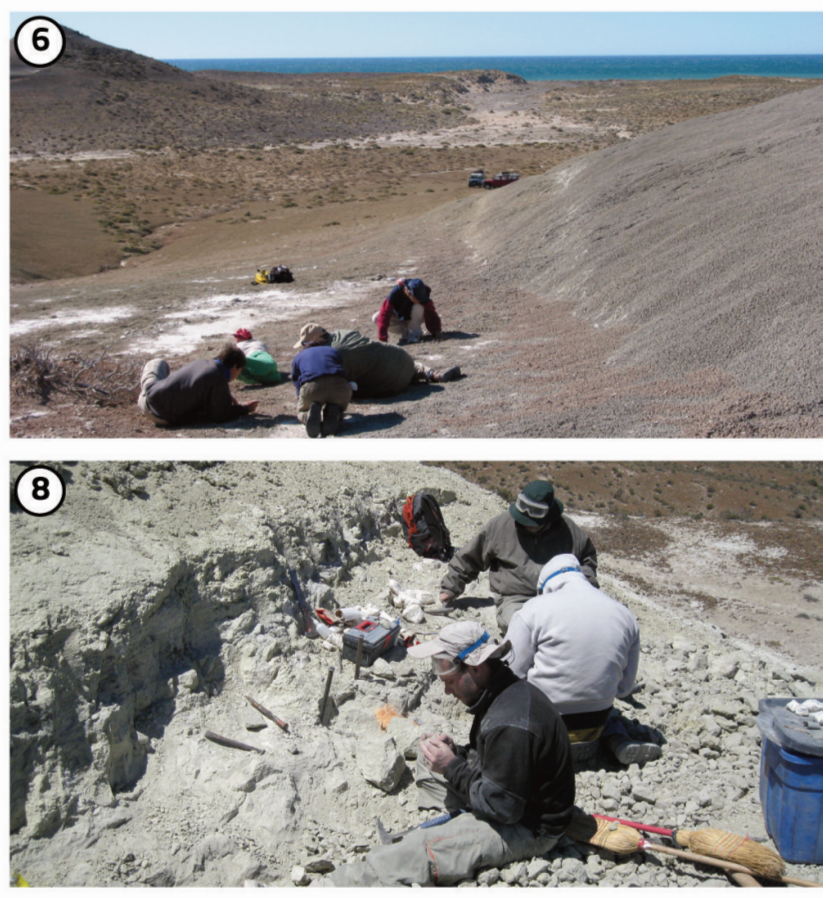

(10)

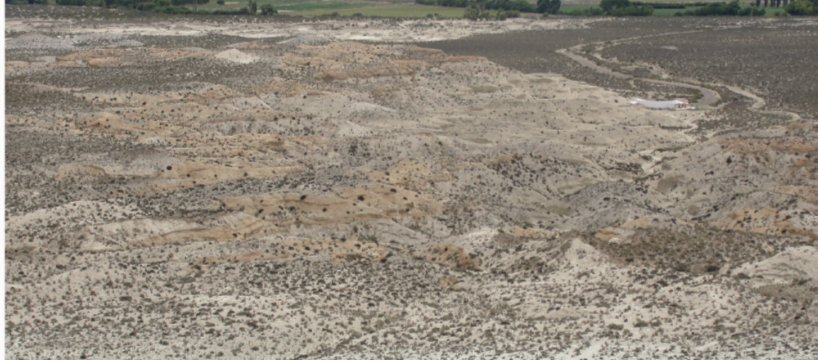


provided by new material. At least four species of chelid turtles are recognized in this area of Punta Peligro-El Gauchito: Yaminuchelus maior, Salamanchelys palaeocenica, Hydromedusa cf. casamayorensis, and a Chelidae indet. (Bona \& de la Fuente, 2005; Bona, 2006). Bonaparte's expedition to Punta Peligro found the holotype of the meiolaniform turtle Peligrochelys walshae described by Sterli and de la Fuente (2013). Recent field works in the area (led by G. Rougier, D. Pol, and J. Sterli) resulted in the discovery of numerous specimens of turtles that significantly increased our knowledge about the diversity of turtles soon after the Cretaceous/Paleocene extinction event (Sterli \& de la Fuente, 2019; this work).

\section{Cañadón Hondo}

In the year 1931 Piatnitzky was the first to find fossils in the Cañadón Hondo area and he was the one who took Simpson to the area. Simpson and his team collected numerous fossils during the Scarritt Patagonian Expeditions of the AMNH (e.g., Simpson, 1937, 1938). The meiolaniid Crossochelys corniger (synonymized with Niolamia argentina by Gaffney, 1996) was named and described by Simpson (1937, 1938). Later, during the 1960s, crews of the Museo Municipal de Ciencias Naturales de Mar del Plata 'Lorenzo Scaglia' (Mar del Plata, Buenos Aires, Argentina), lead by G. Scaglia, prospected the area and found turtle remains that later de la Fuente and Bona (2002) recognized as Hydromedusa casamayorensis. During the 1970s, more turtle remains were collected by E. L. Marshall and O. A. Gutiérrez (specimens housed at MACN), and by R. Pascual and P. Bondesio (specimens housed at MLP). During the early 2000s, a team from MEF collected several specimens of turtles (chelids and meiolaniids) near the Rocas Gemelas locality (Fig. 3.7). Those specimens are housed at MEF and have been described by Sterli et al. (2015) and Maniel et al. (2018). A decade later, in 2010 and 2012, teams from MEF and Museo de Historia Natural de San Rafael (Mendoza, Argentina) conducted the fieldwork in the area, collecting numerous re- mains (housed at MEF; Fig. 3.8). The majority of those remains have been described by Sterli et al. (2015) and Maniel et al. (2018). In the present review, we describe the remaining specimens not described in previous papers.

\section{Bryn Gwyn-Gaiman-Trelew}

Roth (1899) was the first to note the presence of turtles (and other vertebrates) in the outcrops of Chubut river valley. The Scarritt Expeditions (1930-1931; 1933-1934) led by G. G. Simpson established the importance of these outcrops on an international level (Simpson, 1935a, 1935b). Few years after the end of the Scarritt Expeditions, Simpson (1942) created a new species of a tortoise, "Testudo" gringorum, based on a shell found in an unknown collection point in the area by J. Hernández in 1933. This taxon remains, up to now, the oldest species of Testudinidae in South America and is crucial for our understanding of the early evolution of tortoises in the continent. Although the tortoises were found in the terrestrial Sarmiento Formation (Trelew Member, early Miocene), more turtles were also found in the overlying, marine, Gaiman Formation (Burdigalian, early Miocene). These turtles belong to the marine Dermochelyidae clade, representing the first marine turtle fossils found in Argentina (de la Fuente \& Vucetich, 1998). Teams from MEF (Trelew) and CENPAT (Puerto Madryn) frequently visit the outcrops since the 1980's as part of past and ongoing paleontological investigations (Fig. 4.9-4.10). Some of the fossils that have been recovered in recent years are described herein.

\section{THE PRESENT OF CHUBUT FOSSIL TURTLES: PRESENT FINDINGS AND ONGOING STUDIES}

Current ongoing investigations in Chubut are divided into three main categories. First, revision of previously known information and challenge of the validity of known taxa (e.g., Sterli \& de la Fuente, 2011, 2019; Sterli, 2015; Maniel \& de la Fuente, 2016; de la Fuente et al., 2018). Second, continuing the research in 'classic' localities with the description

Figure 4. Localities. 1, 2, Cerro Cóndor, Queso Rallado Locality; 1, 2001; 2, 2010. Left to right: J. M. Leardi, F. Garberoglio, R. O. Gómez, M. Becerra, I. Maniel, and G. W. Rougier. 3, 4, La Colonia; 3, 1996. P. González appears in the picture; 4, 2001. From left to right: M. Cárdenas, B. Cariglino, and A. Gandolfo. 5, 6, Punta Peligro; 5, 1998. From left to right: G. Dalloca, G. Cladera, P. Puerta, and M. Gabelsberger. 6, 2002. From foregram to background: L. Canessa, P. Puerta, M. Cárdenas, G. W. Rougier. 7, 8, Cañadón Hondo; 7, 2003. Below: M. Cárdenas; above: L. Canessa. 8, 2012. From foregram to background: J. Kaluza, P. Puerta, and M. S. de la Fuente. 9, 10, Bryn Gwyn; 9, 1989. From left to right: G. Humbertlan, indet., indet. M. Cozzuol, R. Taylor and P. Puerta. 10, 2020. Picture credits: P. Puerta. 
of new occurrences and new taxa with specific attention to report the new information with accurate stratigraphic and locality information (e.g., Sterli et al., 2013, 2015; Gasparini et al., 2015; Sterli \& de la Fuente, 2019; Oriozabala et al., 2020). Finally, expanding fieldwork and fossil collection in new areas with fossiliferous potential, like in the NW part of Chubut (Oriozabala et al., 2018), and other new localities (Fig. 2).

These ongoing investigations allow the continuous and gradual improvement of our knowledge of the fossil record of turtles in Chubut. Some of this new information is reported in this section.

\section{El Bagual}

Systematics. Testudinata / cf. Condorchelys antiqua (Fig. 5). Referred material. MPEF-PV 3163, left humerus (Fig. 5.15.6); MPEF-PV 3164, costal plate in visceral view (Fig. 5.7). Horizon. Cañadón Asfalto Formation; mid-late ToarcianAalenian (?Bajocian).

Collection point. El Bagual, Chubut Province, Argentina (\#1 in Fig. 2, Suppl. Table).

Collectors. J. L. Carballido, M. Caffa, L. Canessa (2008).

Description. The humerus MPEF-PV 3163 (Fig. 5.1-5.6) is very similar to the humeri known from Condorchelys antiqua. It is a gracile bone, with both ends expanded (the proximal more expanded than the distal). The medial process is bigger than the lateral process and it is continuous with the head of the humerus. A shoulder is present between the head and the lateral process. The lateral process is located below the medial process. In ventral view, a ' $C$ '-shaped concavity intertubercular fossa is present (Fig. 5.3) as in $C$. antiqua and Naomichelys speciosa (Joyce et al., 2014). The shaft of the humerus is narrow. In dorsal view, the distal end is formed by the entepicondyle and the ectepicondyle (posteriorly and anteriorly, respectively). In anterior view, the ectepicondylar foramen is present and there is a groove leading to it. In ventral view, the condyles for the articulation with the radius (capitullum) and the ulna (trochlea) are well differentiated. The costal bone MPEF-PV 3164 (Fig. 5.7) is preserved in visceral view, consequently, there is no much information about it. The preserved element is wider than long (as in regular costals). The relief of the fused rib is seen (marked with a dashed line in Fig. 5.7).

Comments. The type locality of Condorchelys antiqua is Queso Rallado (Sterli, 2008). All the referred material also comes from Queso Rallado (Sterli \& de la Fuente, 2011; Sterli et al., 2019). Although the specimens from El Bagual locality are fragmentary, they show that basal turtles of the Pangean Phase (sensu Vlachos et al., 2018) were also present in other nearby and coeval localities, besides the
(1)

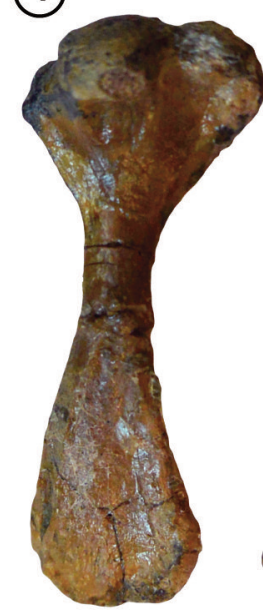

(2)

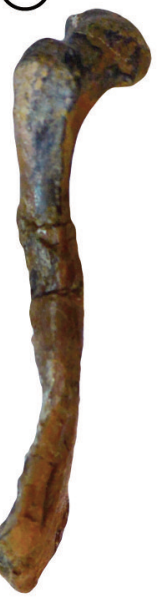

(3)

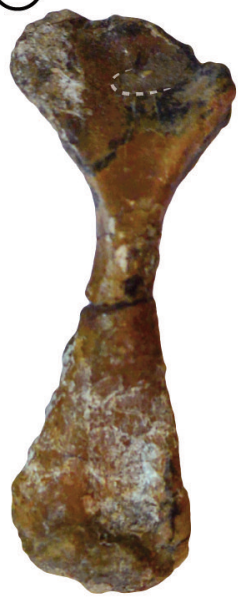

(4)

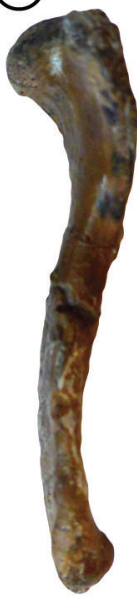

(5)

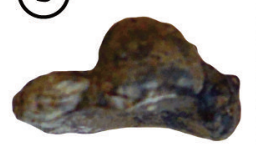

(6)

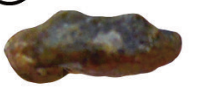

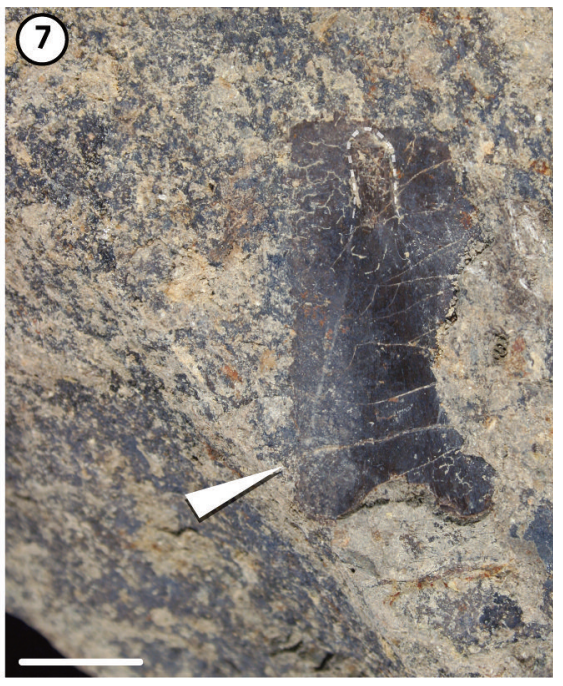

Figure 5. Turtle fossils from El Bagual, Early-Middle Jurassic, Cañadón Asfalto Formation. cf. Condorchelys antiqua. 1-6, MPEF-PV 3163, left humerus in 1, dorsal; 2, anterior; 3, ventral; 4, posterior; 5, proximal; 6, distal views; 7, MPEF-PV 3164, costal plate in visceral view. Scale bars $=1 \mathrm{~cm}$. 
highly abundant Queso Rallado. Based on the similarities between the humerus MPEF-PV 3163 and those known for C. antiqua, we refer this specimen to cf. C. antiqua.

\section{Cerro Mesa}

Systematics. Testudines / Pleurodira / Pan-Chelidae / cf. Prochelidella sp. (Fig. 6).

Referred material. MPEF-PV 3165, bridge peripheral bone (MPEF-PV 3165a; Fig. 6.1-6.5), fragment of suprapygal (MPEF-PV 3165b; Fig. 6.6-6.7), xiphiplastron fragment (MPEF-PV 3165d; Fig. 6.8-6.9), distal end of left humerus (MPEF-PV 3165c; Fig. 6.10-6.13), and other indet. carapacial and postcranial remains.

Horizon. Bardas Coloradas Member, Los Adobes Formation, Chubut Group; early Aptian, Early Cretaceous.

Collection point. Cerro Mesa, Estancia Daniel and Dionide Mesa, Chubut Province, Argentina (\#5 in Fig. 2, Suppl. Table). Collectors. O. Rauhut, P. Puerta (2001).

Description. The same size and the presence of non-repetitive elements could suggest that they belong to one, small individual. The preserved shell remains show a smooth surface with no evident ornamentation (Fig. 6.1-6.9). The bridge peripheral bone (Fig. 6.1-6.5) has a pocket for the articulation with the rib (Fig. 6.3). The fragment of the suprapygal (Fig. 6.6-6.7) has in the visceral view the suture area (scar) for the ilium (Fig. 6.7, arrow). As we can notice a suture for an element of the pelvic girdle (Fig. 6.9, arrow), the specimen figured in Fig. 6.8-6.9 is clearly identified as a part of the xiphiplastron. The distal end of the humerus (Fig. 6.10-6.13) shows an open ectepicondylar foramen (Fig. 6.10-6.11).

Comments. An early Aptian age is suggested for the Bardas Coloradas Member of the Los Adobes Formation (Krause et al., 2020), and this Formation underlays the Puesto La Paloma Member of the Cerro Barcino Formation. Consequently, the fauna found in Bardas Coloradas Member is older than the one from the Cerro Barcino. Although MPEFPV 3165 is very fragmentary, the general description provided above agrees with the morphology (e.g., small size, lack of evident ornamentation) found in the pan-chelid
(1)

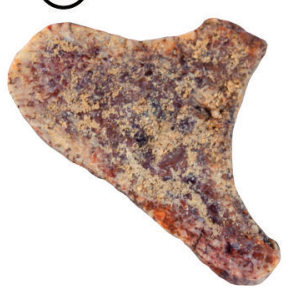

(6)
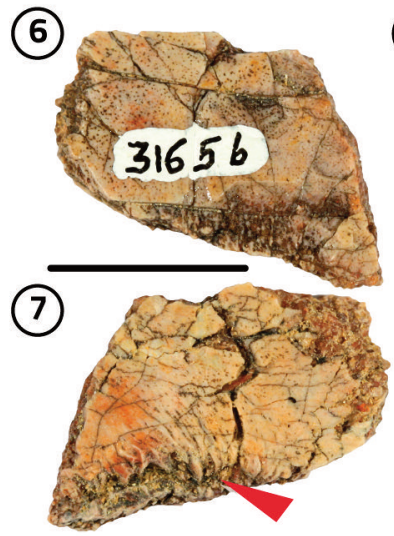

(2)

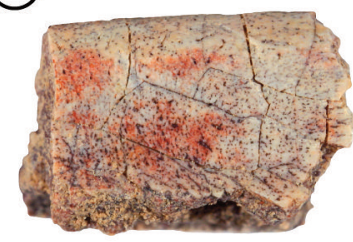

(3)

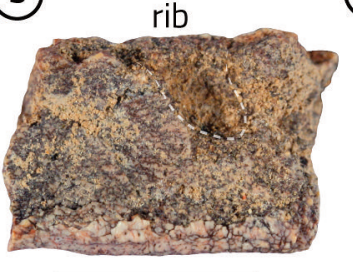

(4)

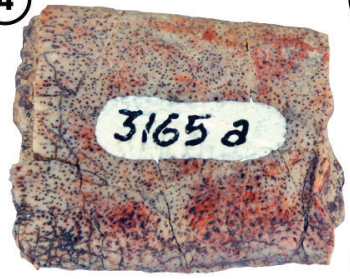

(5)

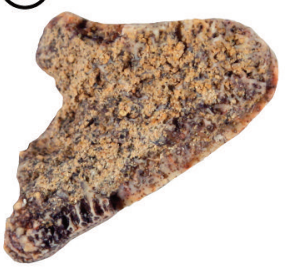

(8)

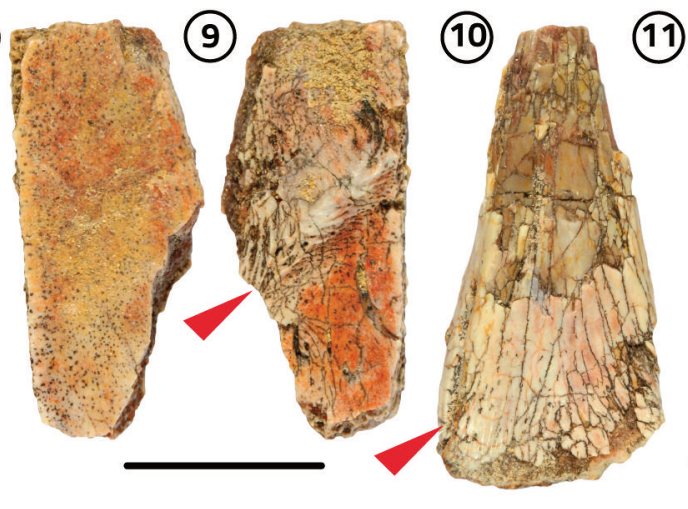

(11)

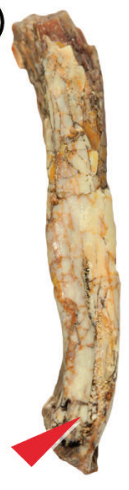

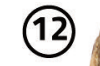

(13)

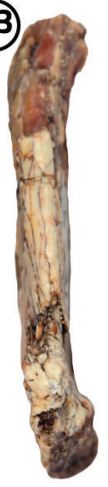

Figure 6. Turtle fossils from Cerro Mesa, Early Cretaceous (Aptian), Bardas Coloradas Member, Los Adobes Formation. MPEF-PV 3165, cf. Prochelidella sp. 1-5, bridge peripheral bone (MPEF-PV 3165a) in 1, anterior; 2, dorsal; 3, visceral; 4, ventral; and 5, posterior views; 6-7, fragment of suprapygal (MPEF-PV 3165b) in 6, dorsal and 7, visceral views; 8-9, xiphiplastron fragment (MPEF-PV 3165d) in 8, ventral and 9, visceral views; 10-13, distal end of left humerus (MPEF-PV 3165c) in 10, anterior; 11, dorsal; 12, posterior; 13 , ventral views. Scale bars= $1 \mathrm{~cm}$. 
turtle Prochelidella spp. This occurrence would be one of the oldest of Pan-Chelidae, even older than P. cerrobarcinae (late Aptian, Puesto La Paloma Member, Cerro Barcino Formation), which is the oldest unambiguous chelid (Maniel \& de la Fuente, 2016; and references therein). In Chubut, there are two species of Prochelidella recognized: $P$. cerrobarcinae, which is recorded nearby Cerro Mesa in the Cerro Chivo locality in outcrops of the Cerro Barcino Formation (Lower Cretaceous; de la Fuente et al., 2011) and P. argentinae from 'Estancia 8 Hermanos' in outcrops of the Bajo Barreal Formation (Cenomanian-Turonian; de Broin \& de la Fuente, 2001).

\section{Estancia Opazo}

Systematics. Testudines / Pleurodira / Pan-Chelidae / cf. Prochelidella sp. (Fig. 7).

Referred material. MPEF-PV 11451/1, neural 3 or 5 (Fig. 7.1, 7.2); MPEF-PV 11451/2, neural; MPEF-PV 11451/3, fragment of suprapygal; MPEF-PV 11451/4, pygal; MPEFPV 11451/5, ?right costal 1; MPEF-PV 11451/6, left costal ?5; MPEF-PV 11451/7, left costal ?5; MPEF-PV 11451/8, ?right costal 5; MPEF-PV 11451/9, left costal 8; MPEF-PV 11451/10, six fragments of unpaired costals; MPEF-PV 11451/11, nine fragments of paired costals (Fig. 7.7, 7.8); MPEF-PV 11451/12, very small paired costal; MPEF-PV 11451/13, two costals 1 with buttresses (Fig. 7.3-7.6); MPEF-PV 11451/14, right peripheral 1; MPEF-PV 11451/15, right bridge peripheral ?3; MPEF-PV 11451/16, left bridge peripheral ?3; MPEF-PV 11451/17, right bridge peripheral ?4; MPEF-PV 11451/18, right bridge peripheral ?4; MPEF-PV 11451/19, right bridge peripheral ?4 (Fig. 7.13-7.14); MPEF-PV 11451/20, ?right bridge peripheral ?6; MPEF-PV 11451/21, left bridge peripheral ?6; MPEFPV 11451/22, left bridge peripheral ?6; MPEF-PV 11451/23, bridge peripheral ?6; MPEF-PV 11451/24, small-sized right bridge peripheral (Fig. 7.9-7.10); MPEFPV 11451/25, bridge peripheral; MPEF-PV 11451/26, bridge peripheral; MPEF-PV 11451/27, bridge peripheral; MPEF-PV 11451/28, bridge peripheral; MPEF-PV 11451/29, bridge peripheral; MPEF-PV 11451/30, very small-sized bridge peripheral (Fig. 7.15-7.16); MPEF-PV 11451/31, ?right bridge peripheral ?7 (Fig. 7.11-7.12); MPEF-PV 11451/32, right bridge peripheral ?7; MPEF-PV
11451/33, left bridge peripheral ?7; MPEF-PV 11451/34, left peripheral 8 or 9; MPEF-PV 11451/35, left free peripheral (small); MPEF-PV 11451/36, left bridge peripheral; MPEF-PV 11451/37, free peripheral (?right); MPEF-PV 11451/38, free peripheral (?left); MPEF-PV 11451/39, free peripheral (?left); MPEF-PV 11451/40, free peripheral; MPEF-PV 11451/41, right peripheral 11 (Fig. 7.17-7.18); MPEF-PV 11451/42, nine fragments of peripherals; MPEFPV 11451/43, right hyoplastron; MPEF-PV 11451/44, left hyoplastron or right epiplastron; MPEF-PV 11451/45, left ?hyoplastron; MPEF-PV 11451/46, ?mesoplastron; MPEF-PV 11451/47, ?mesoplastron; MPEF-PV 11451/48, buttress (Fig. 7.19-7.21); MPEF-PV 11451/49, five hyo/hypoplastral fragments; MPEF-PV 11451/50, left xiphiplastron; MPEF-PV 11451/51, left xiphiplastron; MPEF-PV 11451/52, right xiphiplastron (Fig. 7.22-7.23); MPEF-PV 11451/53, ?xiphiplastron; 11451/53, two plastral remains; MPEF-PV 11451/55, several indet. shell remains; MPEF-PV 11451/56, proximal end of right humerus; MPEF-PV 11451/57, proximal end of left humerus; MPEF-PV 11451/58, right acetabulum; MPEF-PV 11451/59, ?left ilium; MPEF-PV 11451/60, carapace remain indet.

Horizon. Puesto La Paloma Member, Cerro Barcino Formation; late Aptian, Early Cretaceous.

Collection point. Estancia Opazo, Chubut Province, Argentina (\#6 in Fig. 2, Suppl. Table).

Collectors. K. Panzeri, J. P. O'Gorman, P. Puerta (2018).

Description. Neurals are hexagonal in shape (Fig. 7.1-7.2), and the one described herein is crossed by the intervertebral sulcus that is convex in the middle (Fig. 7.1). In the preserved fragments, we can recognize that the pelvic girdle is sutured to the shell (as it is characteristic for PanPleurodira) (Fig. 7.7-7.8, 7.22-7.23). The connection between the carapace and plastron was through ligaments and the connection between the costals and the peripherals was through pegs and sockets (Fig. 7.9-7.16). These specimens show that the maxillary buttress reached costal 1 (as in $P$. cerrobarcinae and $P$. portezuelae) and add the information that inguinal buttress also reached the costal (presumably the costal 5). An isolated buttress (MPEF-PV 11451/48) shows the presence of musk ducts. In this sample, there are at least three ontogenetic stages: very small individuals (estimated carapace length 10-12 cm, 
(1)

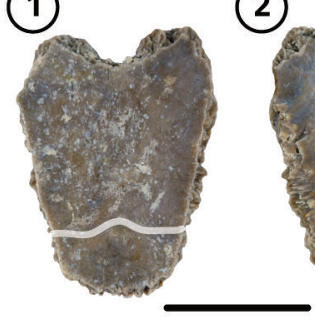

(3)

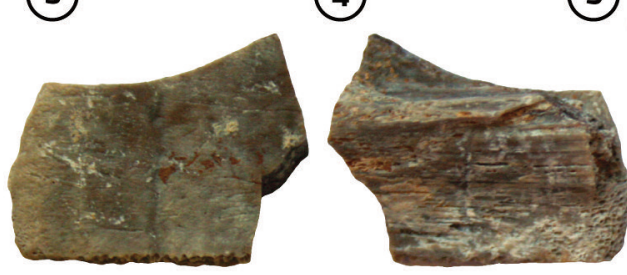

(5)

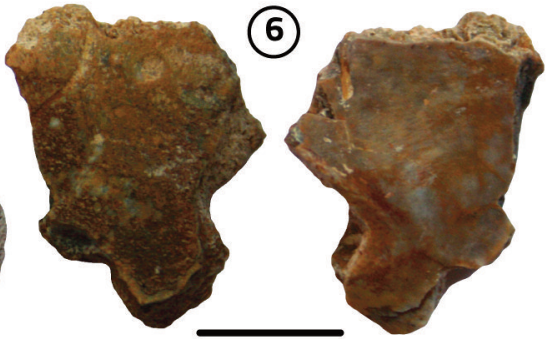

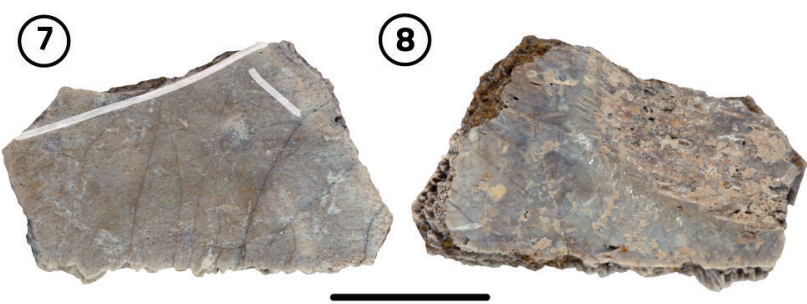

(15)

(13)

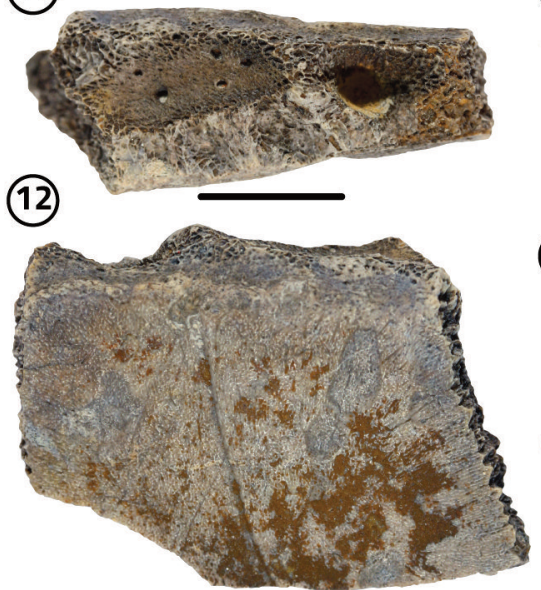

(19)

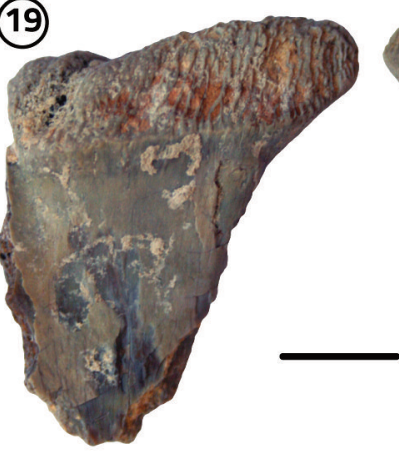

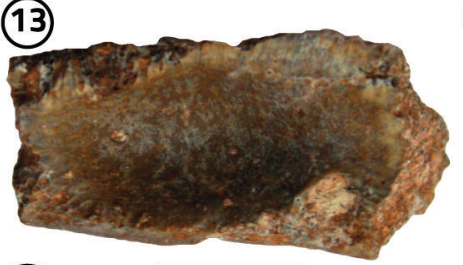

(14)

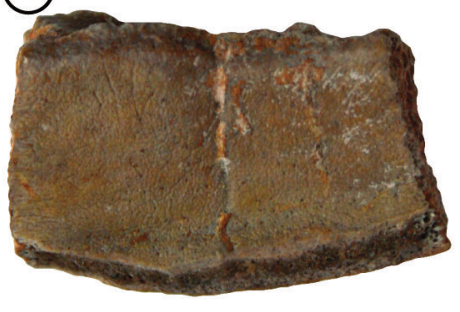

(20)

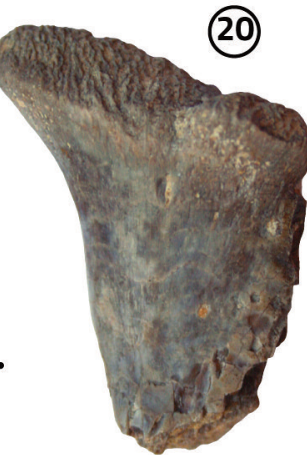

(21)
(16)
(9)

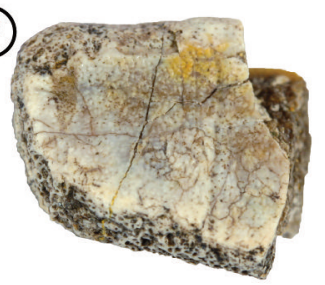

(10)

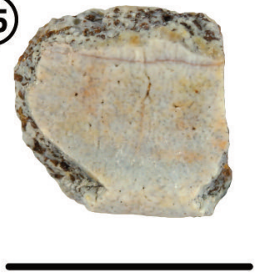

(17)
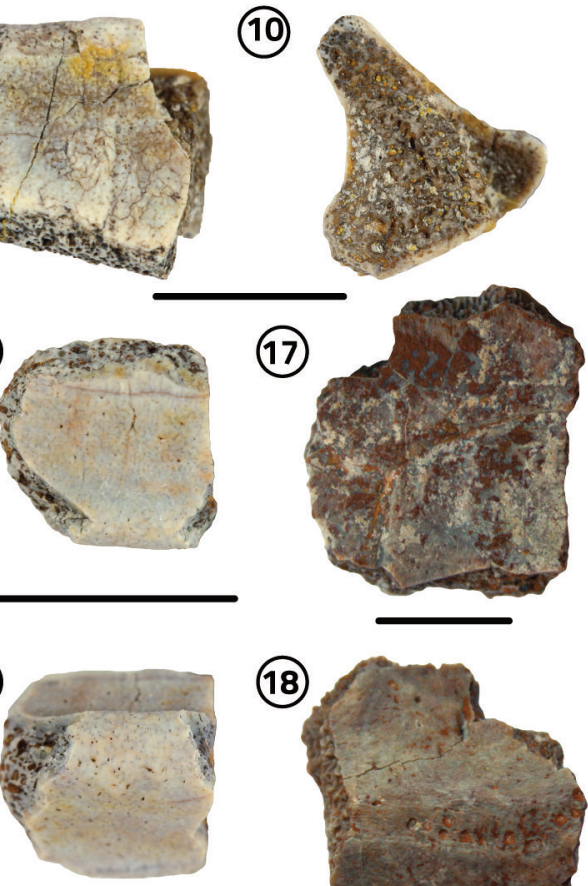

(18)

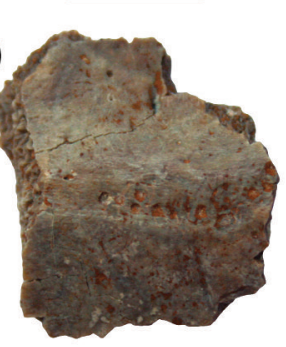

(23)

(22)

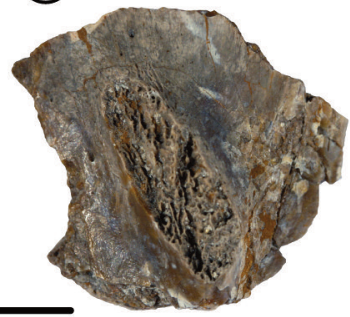

Figure 7. Turtle fossils from Estancia Opazo, Early Cretaceous (Aptian), Puesto La Paloma Member, Cerro Barcino Formation. cf. Prochelidella sp. 1-2, MPEF-PV 11451/1, neural 3 or 5 in 1, dorsal and 2, visceral views; 3-, MPEF-PV 11451/13 left costal 1 in 3, dorsal and 4, ventral views; 5-6, MPEF-PV 11451/13, right costal 1 in 5, dorsal and 6, ventral views; 7-8, MPEF-PV 11451/9, left costal 8 in 7, dorsal and 8, visceral views; 9-10, MPEF-PV 11451/24, right bridge peripheral from a small individual in 9, dorsal and 10, posterior views; 11-12, MPEF-PV 11451/31, ?right bridge peripheral ?7 in 11, medial and 12, dorsal views; 13-14, MPEF-PV 11451/19, right bridge peripheral ?4 in 13, medial and 14, dorsal views; 15-16, MPEF-PV 11451/30, bridge peripheral from a very small individual in 15, dorsal and 16, lateral views; 17-18, MPEF-PV 11451/41, peripheral 11 in 17, dorsal and 18, ventral views; 19-21, MPEF-PV 11451/48, buttress in 19, external; 20, visceral; 21, and medial views; 22-23, MPEF-PV 11451/52, right xiphiplastron in 22, ventral and 23, visceral views. Scale bars= $1 \mathrm{~cm}$. 
MPEF-PV 11451/30; Fig. 7.15-7.16), small individuals (estimated carapace length 12-14 cm, e.g., MPEF-PV 11451/24; Fig. 7.9-7.10), and moderate-sized individuals (estimated carapace length more than $20 \mathrm{~cm}$, e.g., MPEF-PV 11451/31; Fig. 7.11-7.12). At least three differences are found with $P$. cerrobarcinae. First, the inferred size of the larger specimens reported herein is larger than in $P$. cerrobarcinae. Second, the location of the iliac scar in the carapace seems that it did not reach costal 7 in these specimens, while in $P$. cerrobarcinae it reaches costal 7. Finally, the orientation of the sulcus located between vertebral 5 and pleural 4 is horizontal in the present specimen, while in $P$. cerrobarcinae is more vertically oriented.

Comments. There are several turtle remains collected in this locality. Based on their morphology (e.g., lack of evident ornamentation, small size, particular anatomical traits), we assign these remains to $\mathrm{cf}$. Prochelidella sp. The fragmentary nature of these specimens does not allow further description or more precise taxonomic designation. Future, more complete specimens will help to understand whether the mentioned differences are intra- or interspecific.

\section{Tres Cerros}

Systematics. Testudinata / Perichelydia / Meiolaniformes / Meiolaniformes indet. (Fig. 8).

Referred material. MPEF-PV 3271, opisthocoelous caudal vertebra (Fig. 8).

Horizon. Cerro Castaño Member, Cerro Barcino Formation; Albian, Early Cretaceous.

Collection point. Tres Cerros, Chubut Province, Argentina (\#14 in Fig. 2, Suppl. Table).

Collector. J. L. Carballido.

Description. Small (1.4 cm long), opistocoelous caudal vertebra with articulation for chevrons (Fig. 8). The centrum is almost complete, only missing part of the left side and the right process for the chevron (Fig. 8). The neural arch is almost missing, only preserving the base of the right neural arch. The transverse processes are not preserved, however, the base of the right process is preserved. It is located in the posterior part of the centrum. The centrum is longer than high (Fig. 8.2, 8.4). The anterior condyle is round (Fig. 8.1), while the posterior cotyle is oval, being taller than wide (Fig. 8.3).
Comments. Opisthocoelous caudal vertebrae are found in some groups of turtles like meiolaniforms, baenids, chelydrids, platysternids, basal testudinoids, and sinemydidsmacrobaenids (Sterli \& de la Fuente, 2011). Among all those groups of turtles, only meiolaniforms have been found in South America during the Mesozoic and Paleogene, so we tentatively assign this specimen to Meiolaniformes. In this Formation, but in the underlying Puesto La Paloma Member, the meiolaniform Chubutemys copelloi was found, however, no caudal vertebrae are known for this species (Gaffney et
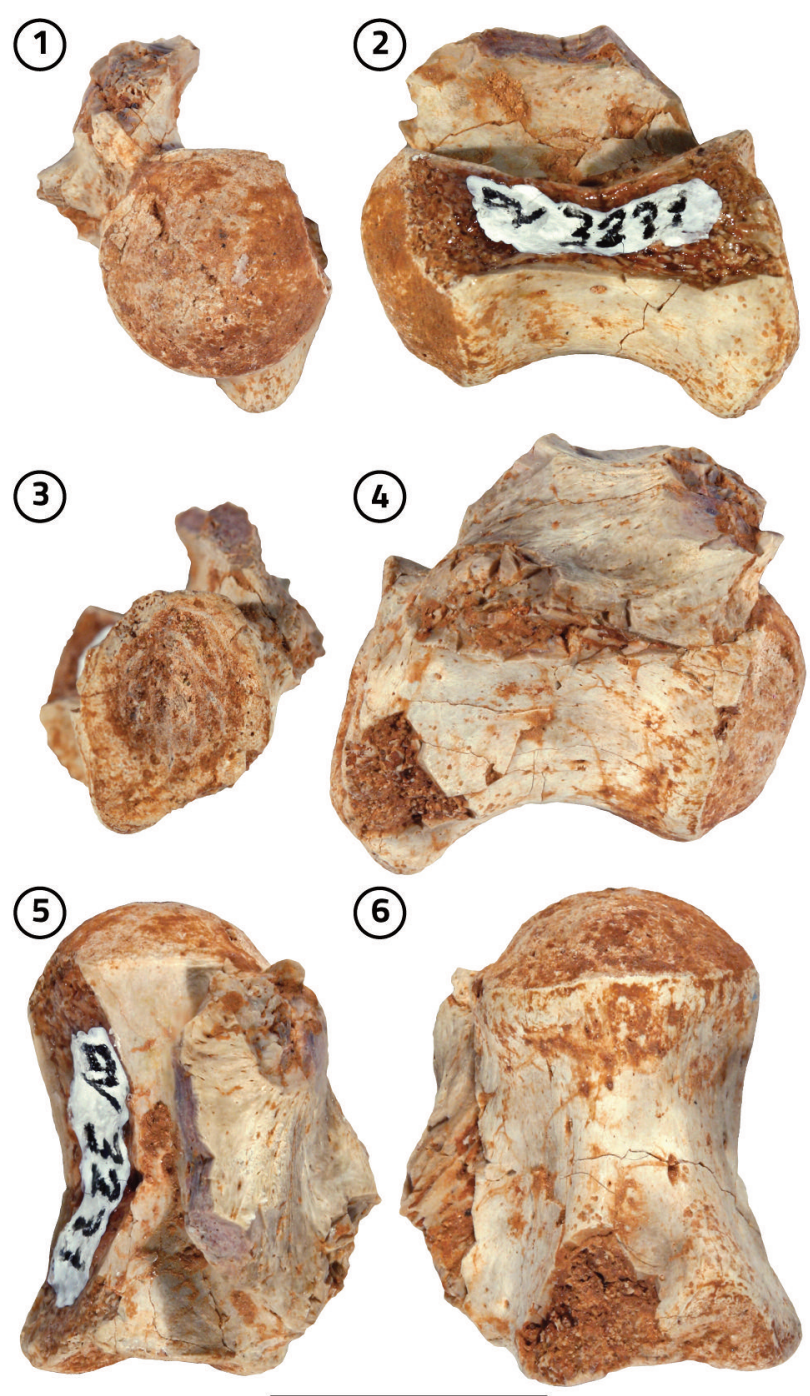

(6)

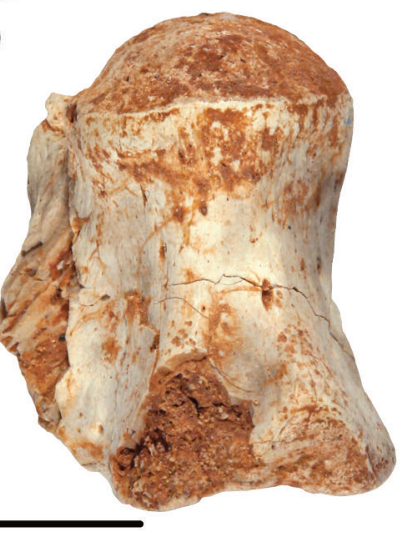

Figure 8. Turtle fossils from Tres Cerros, Early Cretaceous (Albian), Cerro Castaño Member, Cerro Barcino Formation. Meiolaniformes indet. 1-6, MPEF-PV 3271, opisthocoelous caudal vertebra in 1, anterior; 2, left lateral; $\mathbf{3}$, posterior; 4, right lateral; 5, dorsal; 6, and ventral views. Scale bars $=1 \mathrm{~cm}$. 
al., 2007; Sterli et al., 2015). If indeed this vertebra is from a meiolaniform, it helps to start filling the gap between the Aptian record of Chubutemys copelloi and the CampanianMaastrichtian Patagoniaemys gasparinae.

\section{Huanimán}

Systematics. Testudines / Pleurodira / Pan-Chelidae / cf. Prochelidella sp.

Referred material. MPEF-PV 11442, bridge peripheral plate, fragment of costal bone, remains of axillary or inguinal buttresses, and indet. shell remains.

Horizon. Cerro Castaño Member, Cerro Barcino Formation; Albian, Early Cretaceous.

Collection point. Huanimán, Chubut Province, Argentina (\#11 in Fig. 2, Suppl. Table).

Collector. O. Rauhut and P. Puerta (2001).

Description. This specimen is very fragmentary. It includes small indeterminable remains of a turtle shell, a costal bone, a bridge peripheral, and some remains of the axillary or inguinal buttress, not figured herein. The shell fragments show no ornamentation, and the surface is similar to the one observed in Prochelidella spp. The connection between the carapace and plastron was through ligaments and the connection between the costals and the peripherals was through pegs and sockets, respectively.

Comments. Despite the fragmentary nature of this material, the presence of cf. Prochelidella sp. in the Cerro Castaño Member of the Cerro Barcino Formation represents the youngest record of prochelidellas in the SomuncuráCañadón Asfalto Basin and fills the stratigraphic gap between the Albian P. cerrobarcinae and the CenomanianTuronian $P$. argentinae (from the Bajo Barreales Formation, Golfo San Jorge Basin).

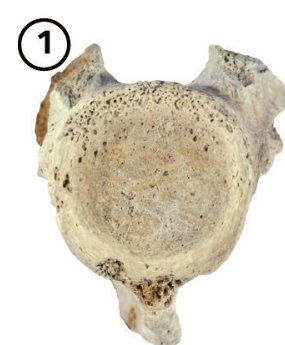

(2)

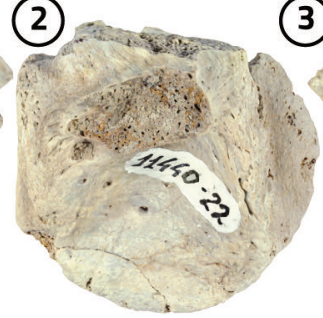

(7)

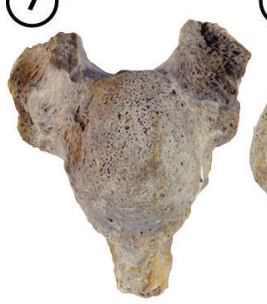

(8)

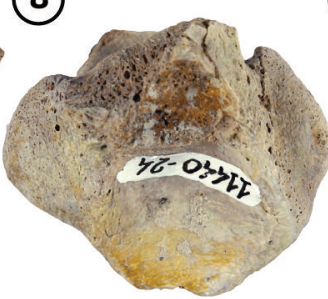

(3)

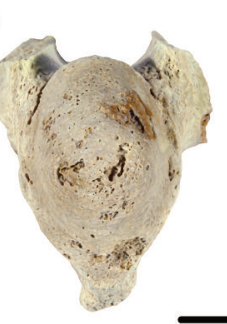

(4)

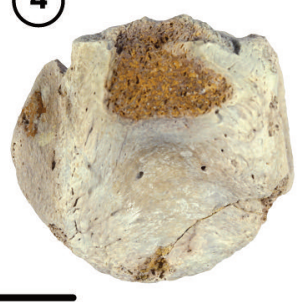

(5)

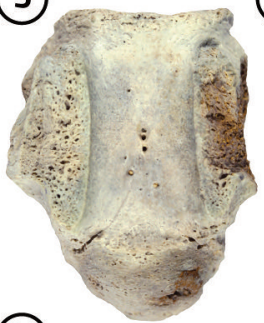

(11)

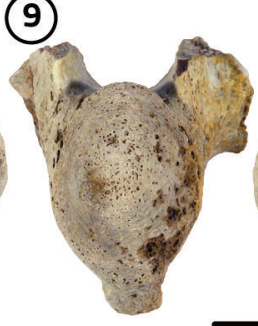

(10)

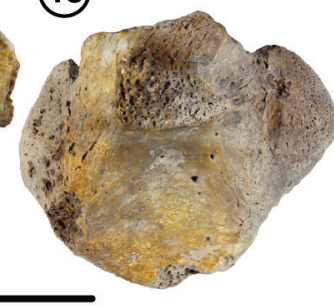

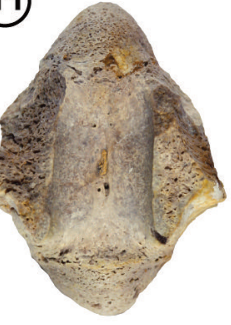

(6)

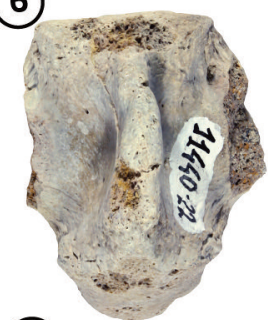

(12)

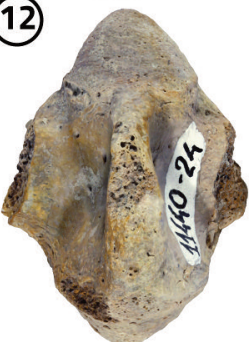

(13)

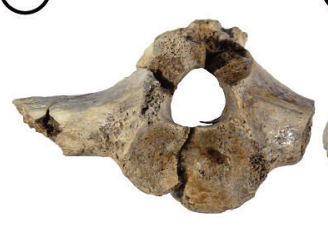

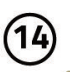

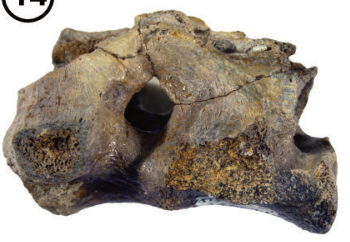

(15)

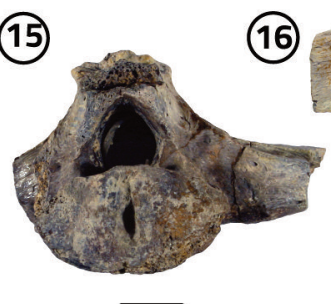

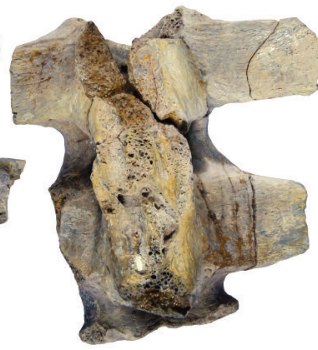

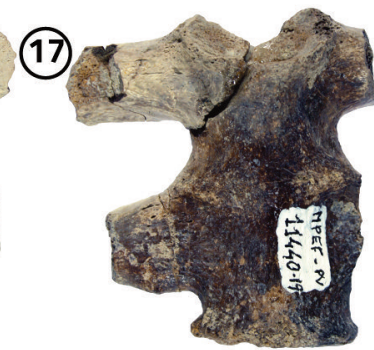

Figure 9. Turtle fossils from Punta Peligro, Paleocene (Danian), Salamanca Formation. Peligrochelys walshae, MPEF-PV 11440. 1-6, cervical vertebrae 6 (MPEF-PV 11440/22) in 1, anterior; 2, left lateral; 3, posterior; 4, right lateral; 5, dorsal; 6, and ventral views; 7-12, cervical vertebra 8 (MPEF-PV 11440/24) in 7, anterior; 8, left lateral; 9, posterior; 10, right lateral; 11, dorsal; 12, and ventral views; 13-17, two sacral vertebrae (MPEF-PV 11440/19) in 13, anterior; 14, left lateral; 15, posterior; 16, dorsal; and 17, ventral views. Scale bars $=1 \mathrm{~cm}$. 


\section{Punta Peligro}

Systematics. Testudinata / Meiolaniformes / Peligrochelys / Peligrochelys walshae (Figs. 9, 10).

Referred material. MPEF-PV 11440, basisphenoid, basioccipital, right opisthotic, both quadrates, right postorbital, fragment of the right dentary, cervical vertebrae (4-6 and 8; Fig. 9.1-9.12), both sacral vertebrae (Fig. 9.13-9.17), two anterior caudal vertebrae, both pectoral girdles (distal end of both coracoids missing), both humeri (Fig. 10.1-10.6), left intermedium, both acetabula (Fig. 10.7), diaphysis of the left femur, left tibia (Fig. 10.8-10.13), diaphysis and distal end of right fibula (Fig. 10.14-10.18), ungual phalanx, right bridge peripheral bone, two plastral remains, indet. shell remains, and indet. postcranial remains (not shell); MPEFPV 11441, fragment of right dentary.

Horizon. Salamanca Formation; Danian, Paleocene.

Collection point. Punta Peligro locality, Chubut Province, Argentina (\#130 in Fig. 2, Suppl. Table).

Collector. G. W. Rougier $(2004,2006)$.

Description. The skeletal elements of MPEF-PV 11440 agree with the published descriptions of Peligrochelys walshae, and allow a clear attribution of MPEF-PV 11440 to this species. In this contribution, we are going to describe only the elements that provide new data about the anatomy of this species. These elements are: cervical vertebrae 6 and 8 , sacral vertebra 1 , humerus, acetabulum, tibia, and right fibula. Only the centra of the cervical vertebrae are preserved. Comparisons with Pe. walshae, Patagoniaemys gasparinae and other turtles resulted in the identification of cervical vertebrae $4-6$ and 8 . Cervical vertebrae 4 and 5 agree with the previously known remains of Pe. walshae. Cervical vertebra 6 is procoelous (Fig. 9.1-9.6). The anterior cotyle is round (Fig. 9.1), while the posterior condyle is oval, with the main axis vertically oriented (Fig. 9.3). The base of the diapophysis and the neural arch are preserved and they are located towards the anterior part of the centrum (Fig. $9.2,9.4)$. The centrum is laterally constricted in the base and continues into a ventral keel developed all along the centrum (Fig. 9.2, 9.4, 9.6). In the ventral part of the anterior cotyle there are small bumps on each side of the keel that we identify as the parapophysis (Fig. 9.1-9.2). Cervical vertebra 8 is biconvex (Fig. 9.7-9.12). Both condyles are oval with the main axis vertically oriented (Fig. 9.7, 9.3). The di- apophysis is located in the middle of the centrum (Fig. 9.8, 9.10). The centrum is laterally constricted and continues into a ventral keel developed all along the centrum (Fig. 9.12). The cervical formula of $P$ e. walshae would be: ?1? ?2 ( (3) (4) (5) (6) ) 7) (8). MPEF-PV 11440 also preserves two articulated sacral vertebrae (1 and 2; Fig. 9.13-17). Sacral vertebra 1 has a concave anterior articulation area (Fig. 9.13), while the posterior articulation is flat and connected with sacral vertebra 2 through a synchondrosis (Fig. 9.15). The transverse process is located in the anterior part of the centrum (Fig. 9.14). This morphology is similar to $P a$. walshae. The sacral and anterior caudal formula would be )sa1| |sa2| |ca1 ( ca2) ([...]. An almost complete humerus is preserved in this new specimen MPEF-PV 11440 (Fig. 10.1-10.6). The morphology is similar to the previously described humeri for Pe. walshae, but in this specimen, as it is almost complete, we can estimate its length which is almost $13 \mathrm{~cm}$ long. The width of both ends cannot be measured because they are broken. The width of the proximal end could be estimated circa $6.5 \mathrm{~cm}$ and the width of the distal end is around $5 \mathrm{~cm}$. We can corroborate that the ectepicondylar foramen is closed (Fig. 10.1-10.2). Both acetabula of the pelvic girdle are preserved, as well as a small fragment of the ischium. The general morphology resembles the pelvic girdle of $P a$. gasparinae. The three bones of the pelvic girdle build the acetabulum (Fig. 10.7). The sutures among those bones are seen in medial view. In the acetabulum the bones are fused (Fig. 10.7). The acetabulum is more or less triangular in shape with rounded angles, and is elongated towards the pubis (Fig. 10.7). There is a small fragment identified as the ventral plate of the left ischium bearing the base of the lateral process. An almost complete left tibia is preserved in this new specimen (Fig. 10.8-10.13). The tibia of Pe. walshae is a robust element, with a wide proximal end (twice the width of the shaft). The articulation area for the femur is not well-preserved (Fig. 10.12). A shallow ridge in the dorsal surface of the tibia is identified as the patellar tendon attachment side (Fig. 10.8). On the lateral part, near the proximal end, there is a rugose area for the gastrocnemius muscle (Walker, 1973; Fig. 10.9). Distally, about 2/3 of the length of the tibia and on the ventral surface, there is a low crest that could correspond with the attachment of the popliteus muscle (Walker, 1973; Fig. 10.10). The distal ar- 

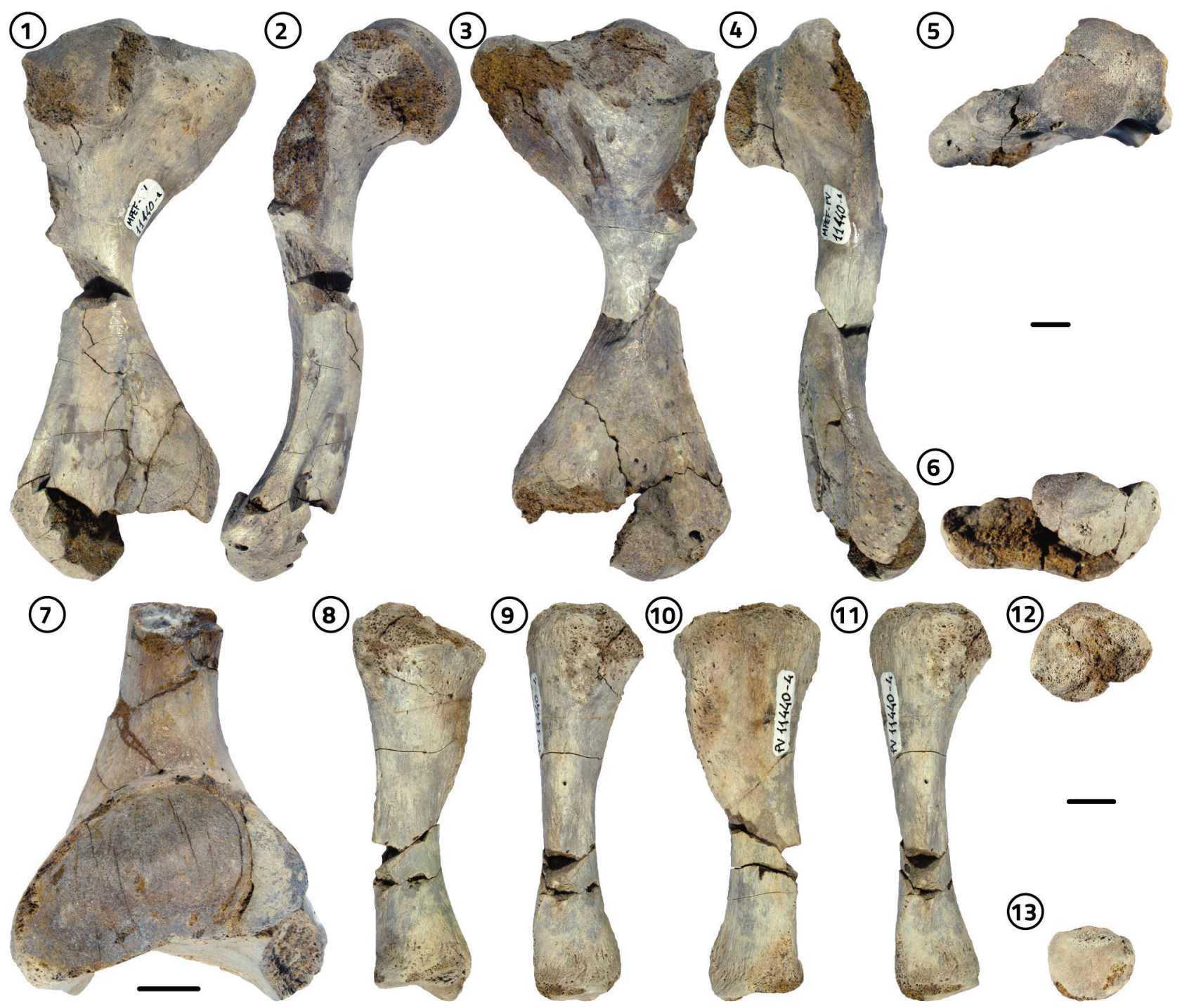

(8)
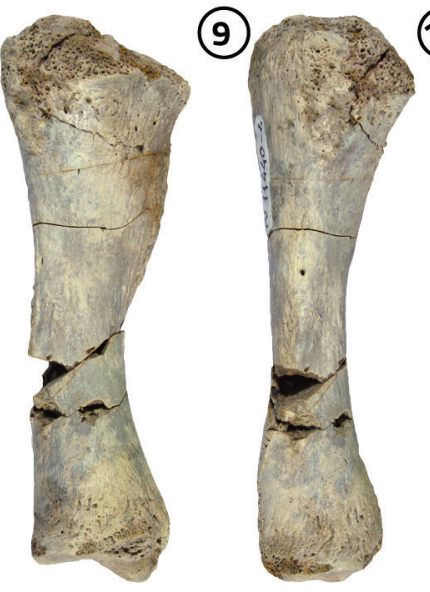

(10)
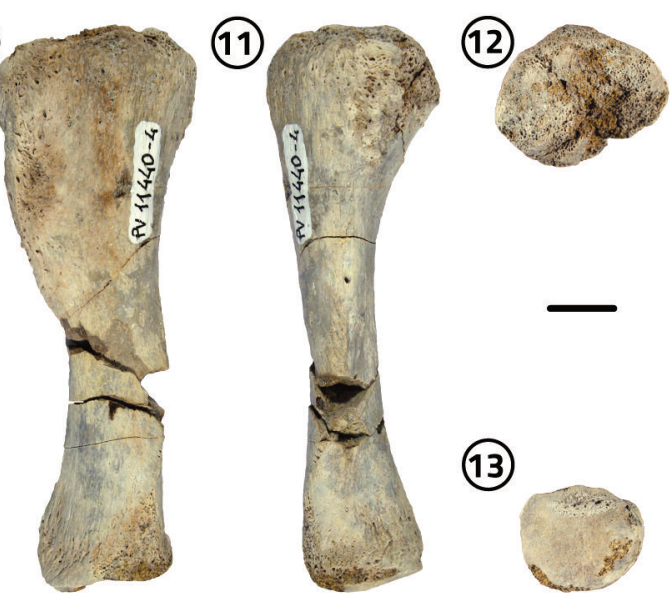

(12)
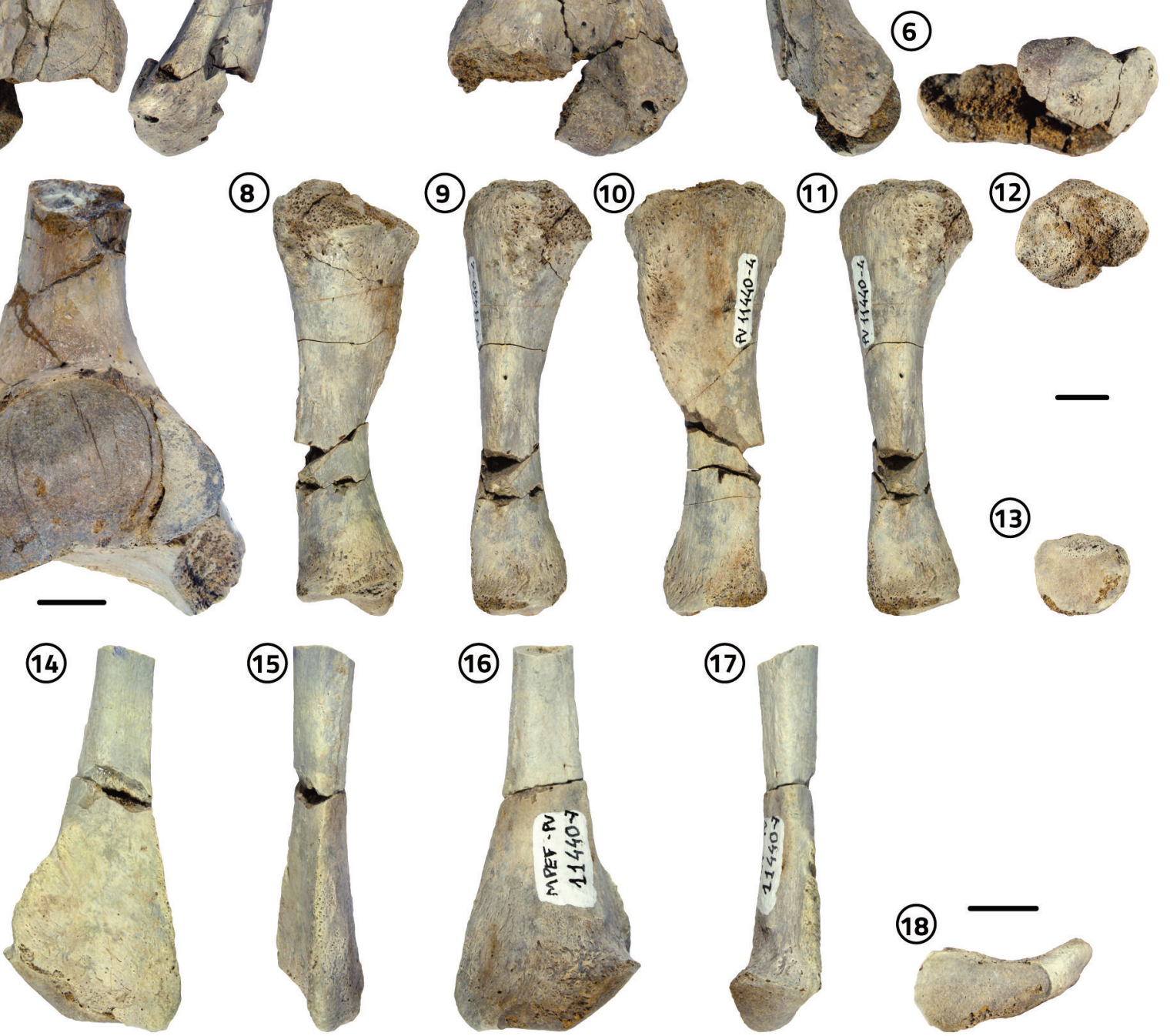

Figure 10. Turtle fossils from Punta Peligro, Paleocene (Danian), Salamanca Formation. Peligrochelys walshae, MPEF-PV 11440. 1-6, humerus in 1, dorsal; 2, anterior; 3, ventral; 4, posterior; 5, proximal; and 6, distal views; 7, left acetabulum (MPEF-PV 11440) in lateral view; 8-13, left tibia (MPEF-PV 11440/4) in 8, dorsal; 9, anterior; 10, ventral; 11, posterior; 12, proximal; and 13, distal views; 14-18, right fibula (MPEF-PV $11440 / 7$ ) in 14, dorsal; 15 , anterior; 16 , ventral; 17 , posterior; and 18, distal views. Scale bars $=1 \mathrm{~cm}$. 
ticulation surface with the astragalocalcaneum has the characteristic medial dome and lateral slightly concave surface (Fig. 10.13). The fibula of Pe. walshae, as in other turtles, has an expanded distal end (Fig. 10.14). The proximal end is missing in this specimen. The shaft is gracile. Near to the distal articular area in the medial part of the fibula, the attachment site for the popliteus muscle (Walker, 1973) is evident (Fig. 10.17). The distal end bears the articulation with the astragalocalcaneum (Fig. 10.18). This articulation is triangular with the base expanded towards the medial side (Fig. 10.18).

Comments. Peligrochelys walshae is one of the most complete meiolaniforms from South America where cranial and postcranial remains are known. The new specimens reported herein help to complete previously unknown parts of the skeleton of this species. Furthermore, as Peligrochelys walshae is the first non-meiolaniid meiolaniform recorded after the K/Pg extinction event, it could help understanding the recovery of the turtle faunas in Patagonia after that extinction event.

\section{Pan de Azúcar}

Systematics. Testudines / Pleurodira / Pan-Chelidae indet. (Fig. 11.1, 11.12).
Referred material. MLP 71-X-12-1, costal 1, fragment of xiphiplastron, and several shell fragments; MPEF-PV 11378 , proximal end of costal bone, part of peripheral, several indet. shell remains (Fig. 11.3-11.4, 11.7-11.8, 11.1111.12); MPEF-PV 11379, left peripheral 1 and indet. shell remains (Fig. 11.5-11.6); MPEF-PV 11380, proximal end of paired costal (2, 4, or 6; Fig. 11.1-11.2), bridge peripheral, and indet. shell remains; MPEF-PV 11381, free peripheral bone and indet. shell remains.

Horizon. Las Flores Formation; Ypresian, early Eocene.

Collection point. Pan de Azúcar, Gaiman, Chubut Province, Argentina (\#174 in Fig. 2, Suppl. Table).

Collectors. MLP material collected by Odreman and J. Laza. MPEF-PV materials collected by L. Chornogubsky, M. E. Pérez, P. Puerta, A. Villafañe (2007).

Description. In general, the plates assigned to this taxon are gracile plates with no ornamentation and thin, delicate sulcus (Fig. 11.1-11.12). The most outstanding plate is a peripheral 1 (MPEF-PV 11379) that is covered by four scutes, marginals 1 and 2, vertebral 1, and pleural 1 (Fig. 11.5-11.6). Among MLP 71-X-12-1 fragments, the most interesting plates are costal 1 and a fragment of xiphiplastron. Costal 1 indicates that the axillary buttress reached the costal 1. In the visceral side of the xiphiplastron, the sutural area with

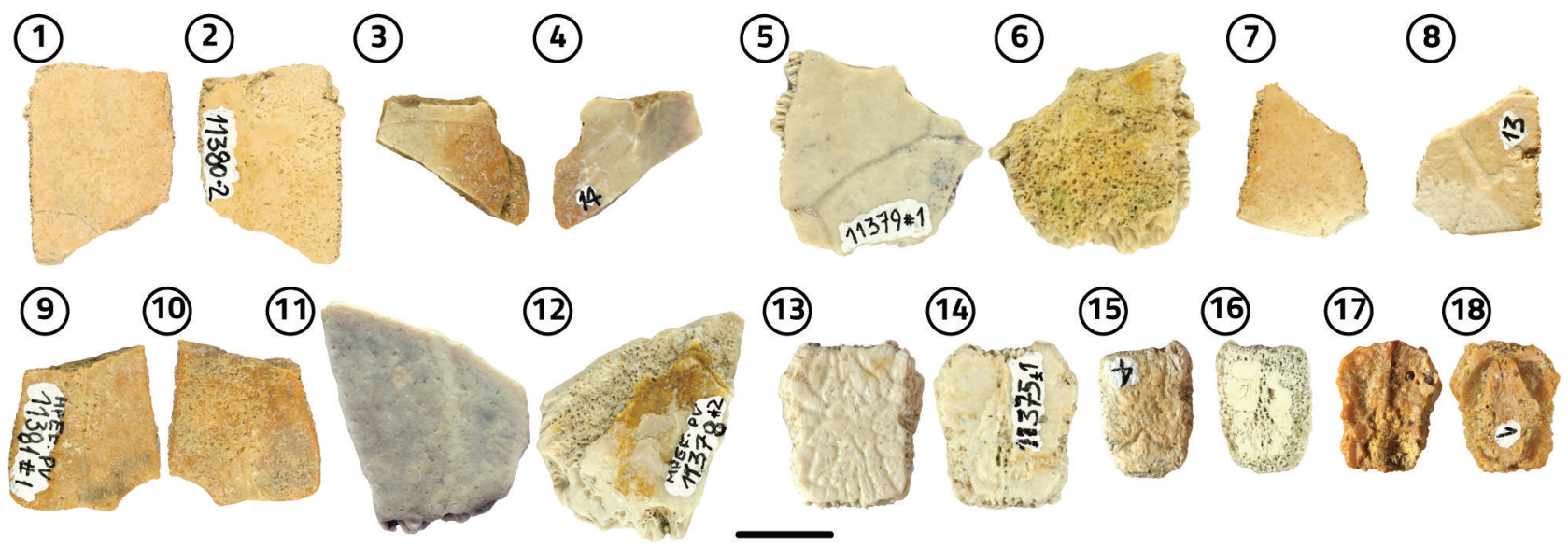

Figure 11. Turtle fossils from Pan de Azúcar, early Eocene (Ypresian), Las Flores Formation. 1-12, Pan-Chelidae gen. et sp. indet. 1-2, MPEFPV $11380 / 2$ paired costal $(2,4$, or 6$)$ in 1 , dorsal and 2 , visceral views; $3-4$, MPEF-PV $11378 / 14$ costal $(3,5$, or 7$)$ in 3 , dorsal and 4 , visceral views; 5-6, MPEF-PV 11379/1, peripheral 1 with four scutes in 5, dorsal and 6, visceral views; 7-8, MPEF-PV 11378/13, free peripheral in 7, dorsal and 8, ventral views; 9-10, MPEF-PV 11381/1, free peripheral plate in 9, dorsal and 10, ventral views; 11-12, MPEF-PV 11378/2, plastron fragment in 11, dorsal and 12, visceral views; 13-18, cf. Hydromedusa sp. 13-14, MPEF-PV 11375/1, paired neural (probably 2) in 13, dorsal and 14, ventral views; 15-16, MPEF-PV 11375/4, neural (probably 5) in 15, dorsal and 16, ventral views; 17-18, MPEF-PV 11377/1, paired neural (probably 4 ) in 17 , dorsal and 18 , ventral views. Scale bar $=1 \mathrm{~cm}$. 
the pubis is preserved, indicating it is a pleurodire.

Comments. The lack of ornamentation and the morphology of peripheral 1, together with the known Patagonian record of turtles, lead us to assign these specimens to Pan-Chelidae. Unfortunately, due to the fragmentary nature of the specimens we cannot say whether these specimens are juveniles or small-sized adults. However, these specimens are important because they help, together with other specimens belonging to other taxa reported herein (see below), filling the Ypresian gap in the fossil record of Chubutean turtles. Also, these records help to establish the presence of turtles in the northern part of Chubut during the Paleogene. It is important to clarify that these specimens (although not identifiable beyond the family level) are clearly different from the ornamented fragments found in the same locality (see next section), indicating the presence of at least two different pan-chelid taxa in the Ypresian of Pan de Azúcar.

Systematics. Testudines / Pleurodira / Chelidae / cf. Hydromedusa sp. A (Fig. 11.13-11.18).

Referred material. CPBA-V 14179, shell fragments; MLP 71-X-12-1, peripherals, costal, neurals, and several shell fragments; MPEF-PV 11375, even, hexagonal neural (probably number 2; Fig. 11.13-11.14), odd neural (probably number 5; Fig. 11.15-11.16), and indet. shell fragment; MPEF-PV 11376, two proximal ends of costals, distal end of paired costal, fragment of peripheral, and indet. shell fragment; MPEF-PV 11377, paired neural bone (probably number 4; Fig. 11.17-11.18) and fragment of peripheral.

Horizon. Las Flores Formation; Ypresian, early Eocene.

Collection point. Pan de Azúcar, Gaiman, Chubut Province, Argentina (\#174 in Fig. 2, Suppl. Table).

Collectors. MLP material collected by Odreman and J. Laza. MPEF-PV materials collected by L. Chornogubsky, M. E. Pérez, P. Puerta, and A. Villafañe (2007).

Description. The recovered neurals are all hexagonal, longer than wide, and with short anterolateral borders. Even neurals (e.g., Fig. 11.13-11.14, 11.17-11.18) are not crossed by any sulci, whereas odd ones (e.g., Fig. 11.15-11.16) are crossed by the intervertebral sulcus that is strongly convex in the middle. One of them (Fig. 11.17, 9.18) is not well-preserved, but it shows the presence of a ridge on the dorsal surface.
Comments. The size, thickness, and ornamentation of the plates described herein resemble the morphology observed in the extant $H$. tectifera and the only Hydromedusa identified in the Chubutean fossil record, $H$. casamayorensis (de la Fuente \& Bona, 2002; Maniel et al., 2018). However, and due to the lack of diagnostic features in the preserved specimens of Pan de Azúcar, we cannot assign them to $H$. casamayorensis - and not even to Hydromedusa-but their morphology clearly reminds this genus. If the presence of Hydromedusa is confirmed in the Ypresian of Patagonia, this record would fill the gap between the Danian Hydromedusa cf. casamayorensis found in Punta Peligro area (Bona, 2006) and the Lutetian $H$. casamayorensis from Cañadón Hondo area (Sarmiento Formation; de la Fuente \& Bona, 2002; Maniel et al., 2018).

\section{Cañadón Hondo}

Systematics. Testudines / Pleurodira / Chelidae / Hydromedusa I Hydromedusa casamayorensis (Figs. 12-13).

Referred material. MACN-Pv 18463, several shell remains not well preserved; MACN-Pv 18480, costal and peripheral plates; MLP, 75-II-1-27, shell remains not well preserved; MPEF-PV 1779, although four plates have the same collection number, they are different individuals; MPEF-PV 1779/1, entoplastron (Fig. 13.4, 13.5); MPEF-PV 1779/2, left peripheral 3; MPEF-PV 1779/3, right hyoplastron; MPEF-PV 1779/4, right hyoplastron; MPEF-PV 1780, although four plates have the same collection number, they are different individuals; MPEF-PV 1780/1, distal end of unpaired costal; MPEF-PV 1780/2, proximal end paired costal; MPEF-PV 1780/3, distal end of right peripheral 1; MPEFPV 1780/4, proximal end paired costal; MPEF-PV 1780/5, mid part of paired costal; MPEF-PV 1780/6, right hypoplastron; MPEF-PV 1780/7, free peripheral; MPEF-PV 1780/8, indet.; MPEF-PV 1780/9, left hypoplastron; MPEFPV 1780/10, unpaired costal; MPEF-PV 1780/11: nuchal; MPEF-PV 1780/12, suprapygal; MPEF-PV 1780/13, right xiphiplastron; MPEF-PV 1780/14, right xiphiplastron (Fig. 13.18-13.21); MPEF-PV 1780/15, right hypoplastron; MPEF-PV 1780/16, nuchal; MPEF-PV 1780/17, distal end right costal 1; MPEF-PV 1780/18, proximal end left costal 1; MPEF-PV 1780/19, free peripheral; MPEF-PV 1780/20, right peripheral 3; MPEF-PV 1780/21, proximal end of un- 
paired costal; MPEF-PV 1780/22, left peripheral 8; MPEFPV 1780/23, right costal 8; MPEF-PV 1780/24, paired neural (2 or 4); MPEF-PV 1780/25, distal end of right costal 8; MPEF-PV 1780/26, left bridge peripheral; MPEF-PV 1780/27, entoplastron (Fig. 13.8-13.9); MPEF-PV 1780/28, free peripheral; MPEF-PV 1780/29, proximal end of left costal 1; MPEF-PV 1780/30, proximal end of left costal 3; MPEF-PV 1780/31, neural 5; MPEF-PV 1780/32, left peripheral 7; MPEF-PV 1780/33, peripheral ?8; MPEF-PV 11364, left peripherals 1 and 2, right peripheral 7, one left bridge peripheral, two right free peripherals, both proximal ends of costal 1 , several fragments of paired costals, left costal 8 , right epiplastron, both hyoplastra, left hypoplastron and left xiphiplastron, and fragments of axillar or/and inguinal buttresses (Fig. 13.1-13.3); MPEF-PV 11365, left peripheral 1, right peripherals 10 and 11, indet. peripheral, pygal, proximal end left costal 1, other fragment of paired costal, entoplastron (Fig. 13.10-13.11), right hyoplastron, left hypoplastron, tip of right xiphiplastron, and axillar or inguinal buttress; MPEF-PV 11366, left peripheral 1, 2 paired costals, indet. costal, right posterior peripheral, and both hyoplastra (Fig. 11.16-11.17); MPEF-PV 11367, nuchal, both peripherals 1, left peripheral 2, neural 1, left costal 1, other associated costals (Fig. 12); MPEF-PV 11368, right peripherals 1 and 2, right posterior peripheral, three left posterior peripherals, two paired costals, one unpaired costal, fragment of left epiplastron, part of right hypoplastron, tip of left xiphiplastron, and indet. plastral remains; MPEF-PV 11383, paired costal, proximal end of costal indet., posterior peripheral, left epiplastron, left hypoplastron, and indet. plastral fragments; MPEF-PV 11384, left hyoplastron (Fig. 13.12-13.13) and right peripheral; MPEF-PV 11385, left peripheral 3, left hyoplastron, and left epiplastron; MPEFPV 11386, several shell remains poorly preserved from at least five individuals: $11386 / 1-4$, four right costal 1; 11386/5-23, 19 paired costals; $11386 / 24-32$ one left costal 8; 11386/33, one paired neural ( 2 or 4); $11386 / 34-$ 37 , four suprapygals; $11386 / 38-41$, four left bridge peripherals; 11386/42, one right peripheral 8; 11386/43-50, eight free peripherals; 11386/51-55, five left epiplastra; 11386/56-57, two right epiplastra; 11386/58, fragment of one entoplastron; 11386/59, one left hyoplastron; 11386/60-62, three right hyoplastra; 11386/63, one hyoplastron; 11386/64, one hyo/hypoplastron; 11386/6567, three left hypoplastra; 11386/68-69, two right hypoplastra; 11386/70-71, two left xiphiplastra; 11386/72, fragment of ilium; and several indeterminate shell and plastral remains are recognized in the sample; MPEF-PV 11389, several shell remains from at least six specimens; 11389/1, one neural; 11389/2, fragment of one suprapygal; 11389/3-5, three right costal $1 ; 11389 / 6-8$, three left

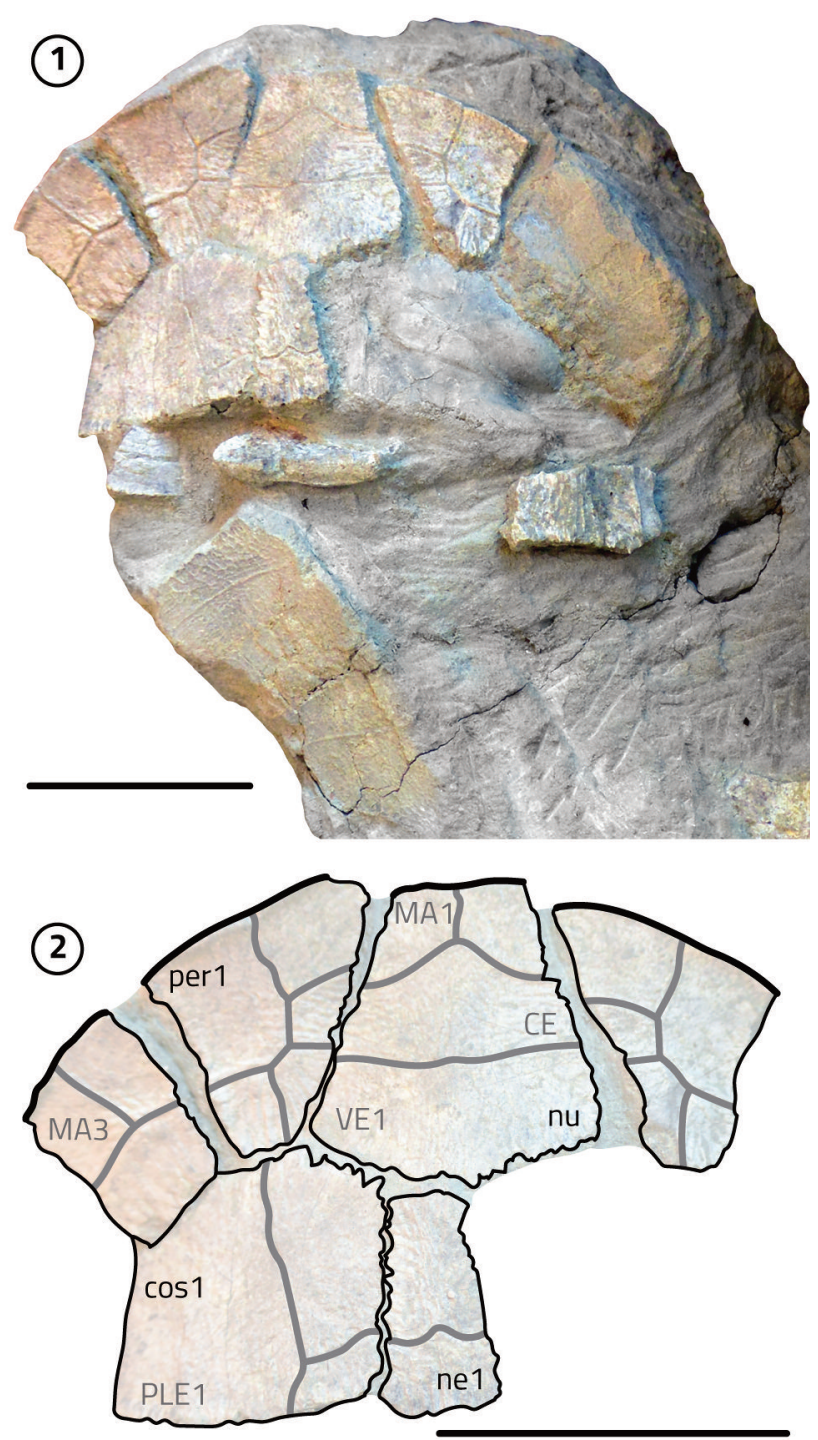

Figure 12. Turtle fossils from the Cañadón Hondo area, Eocene (Lutetian), Sarmiento Formation. Hydromedusa casamayorensis. MPEF-PV 11367. 1, photograph of the anterior part of the carapace. 2, drawing of the anterior part of the carapace. Abbreviations (bony plates with small letters; horny scutes with capital letters): $\mathrm{CE}$, cervical; cos, costal; MA, marginal; ne, neural; nu, nuchal; per, peripheral; PLE, pleural; VE, vertebral. Scale bar $=5 \mathrm{~cm}$. 

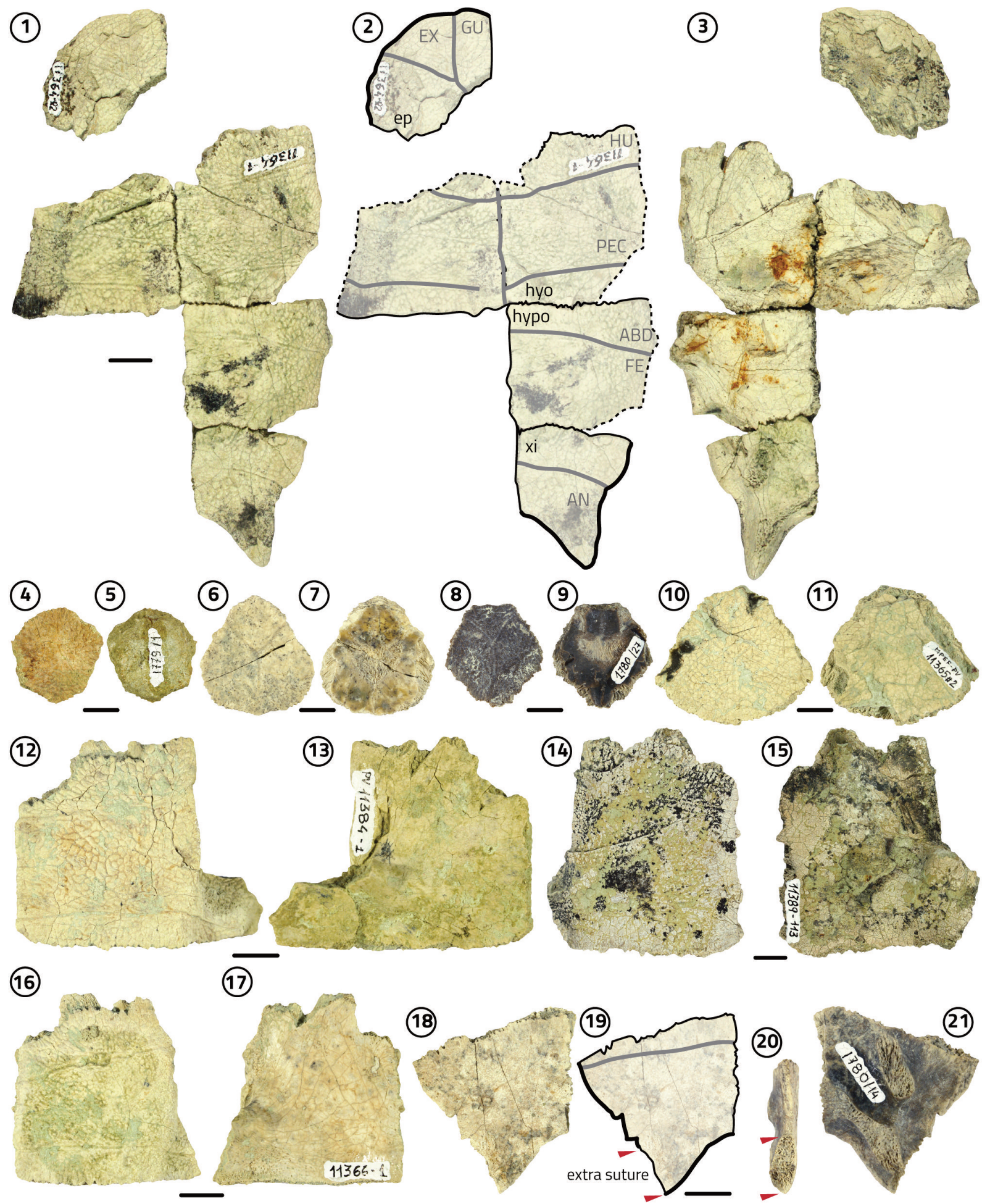

Figure 13. Turtle fossils from the Cañadón Hondo area, Eocene (Lutetian), Sarmiento Formation. Hydromedusa casamayorensis. 1-3, MPEF-PV 11364/1 and 2, plastron; 1-2, plastron in ventral view; 3, plastron in visceral view; 4-11, entoplastra; 4-5, MPEF-PV 1779/1, entoplastron in 4, ventral and 5, visceral views; 6-7, MPEF-PV 11390/67, entoplastron in 6, ventral and 7, visceral views; 8-9, MPEF-PV 1780/27, entoplastron in 8, ventral and 9, visceral views; 10-11, MPEF-PV 11365/2, entoplastron in 10, ventral and 11, visceral views; 12-13, MPEF-PV $11384 / 1$, left hyoplastron in 12, ventral and 13, visceral views; 14-15, MPEF-PV 11389/113, right hyoplastron in 14, ventral and 15, visceral views; 16-17, MPEF-PV 11366/1, left hyoplastron in 16, ventral and 17, visceral views; 18-21, MPEF-PV 1780/14, right xiphiplastron in 18-19, ventral; 20, lateral; and 21, visceral views. Arrows indicate the suture with an extra element in the xiphiplastron. Scale bars= $1 \mathrm{~cm}$. Abbreviations (bony plates with small letters; horny scutes with capital letters): ABD, abdominal; AN, anal; ep, epiplastron; EX, extragular; FE, femoral; GU, gular; HU, humeral; hyo, hyoplastron; hypo, hypoplastron; PEC, pectoral; xi, xiphiplastron. 
costal 1; 11389/9-16, eight odd costals; 11389/17-29, 13 paired costals; 11389/30-44 indet. costals; $11389 / 45$, one left peripheral 1; 11389/46-65, 20 free peripherals; 11389/66-67, two left peripheral 8; 11389/68, one right peripheral 9; 11389/69-82, 14 bridge peripherals; 11389/83, one right peripheral 3; 11389/84, one right peripheral 7; 11389/85-86, two suprapygals; 11389/87, one left epiplastron; 11389/88-89, two entoplastra; 11389/90-95, six left hyoplastra; 11389/96-98, three right hyoplastra; 11389/99, one left hypoplastron; 11389/100-102, three right hypoplastra; 11389/103-104, two left xiphiplastra; 11389/105-106, two right xiphiplastra; 11389/107-108, two ilia (one right and one left from different individuals); 11389/109, one left costal 8; 11389/110-111, two right peripheral 1; 11389/112, one left peripheral 1; 11389/113, right hyoplastron (big specimen; Fig. 13.14-13.15); MPEF-PV 11390, several shell remains from at least two specimens: 11390/1-2, two paired neurals ( 2 or 4 ); $11390 / 3-6$, four odd neurals (3 or 5); 11390/7, fragment of one suprapygal; 11390/8-9, two left costal 1; 11390/10, one right costal 1; 11390/11-18, eight paired costals; 11390/19-35, 17 odd costals; 11390/36, one right costal $8 ; 11390 / 37-40$, four bridge peripherals (2 left, 2 right); 11390/41-65, 25 free peripherals (two peripherals 9, one left and one right); 11390/66, one pygal; 11390/67-68, two entoplastra (Fig. 13.6, 13.7); 11390/69-72, four right xiphiplastra; 11390/73, one left peripheral 1; 11390/74-75, two left epiplastra; 11390/76, one right epiplastron; 11390/77, one left hypoplastron; 11390/78, one left peripheral 9; 11390/79, one free peripheral; 11390/80, one paired costal, and indet. shell and plastral fragments.

Horizon. Sarmiento Formation; Lutetian, middle Eocene.

Collection points. Several occurrences in Cañadón Hondo area, Chubut Province, Argentina (\#151-153, 165, 172 in Fig. 2, Suppl. Table).

Collectors. MACN material collected by E. L. Marshall and O. A. Gutiérrez. MLP specimens collected by R. Pascual and P. Bondesio. MPEF-PV materials collected by M. S. de la Fuente, I. Maniel, D. Pol, P. Puerta, J. Sterli (2010, 2011).

Description. The anatomy of all these specimens agrees with the detailed description recently presented for $H$. casamayorensis (Maniel et al., 2018). Consequently, we are not going to repeat the description here. However, based on the recent work of Maniel et al. (2018) we are going to comment on the size and the morphological variation we found in these new materials presented here (Figs. 12-13) in comparison with the previously published specimens. Maniel et al. (2018) found intraspecific variation in the following bones: nuchals, entoplastra, and xiphiplastra. Three nuchal bones are preserved in these new specimens (MPEFPV 1780/11, 1780/16 and 11367) and only one is complete. The complete nuchal (MPEF-PV 11367) is longer than wide (Fig. 12). Nine entoplastra are preserved among the new specimens (MPEF-PV 1779/1, 1780/27, 11365, 11386/58 and 70, 11389/88-89, 11390/67-68). MPEF-PV 1779/1 is slightly longer than wide and the gular scute extends over half of the entoplastron (Fig. 13.4-13.5), while 11390/67 is also slightly longer than wide, but the gular scutes seem to only cover part of the anterior portion of the entoplastron (Fig. 13.6-13.7). MPEF-PV 11365 is wider than long and the gular scute extends over half of the entoplastron (Fig. 13.10-13.11). Also, there is an apparent variation in their shape (pending on completion of some specimens), with some entoplastra being more hexagonal (Fig. 13.4-13.5), others more rhomboidal (Fig. 13.8-13.9; anterior tip is broken), and some teardrop-shaped with a rounded and wide posterior half (Fig. 13.6-13.7, 13.10-13.11). Thirteen xiphiplastra are recognized in this new sample (1780/1314, 11364, 11365, 11368, 11389/103-106, 11390/69-72). Most of them are broken, so the morphology cannot be assessed with certitude. MPEF-PV 11364 is complete and it is longer than wide. The $\mathrm{U}$-shaped anal notch is present in specimens MPEF-PV 1780/14, 11364, and 11389/106 (Fig. 13.1-13.3, 13.18-13.19), while the V-shaped anal notch is present in 11389/103. In visceral view, the ischiadic scar extends over the plastral tip in specimens MPEF-PV 1780/14, 11364, 11365, 11389/103, 11389/106, and $11390 / 69$ (Fig. 13.3, 13.21). It is worth mentioning that xiphiplastron MPEF-PV 1780/14 presents an unusual sutural surface towards the tip of the xiphiplastron (Fig. 13.18-13.21, arrows). It seems in this specimen there was an extra ossification forming part of the xiphiplastral tip (Fig. 13.18-13.21).

While studying this material, we also found some variation in the location and shape of the humero-pectoral sulcus 
(Fig. 13.12-13.17). While in specimens MPEF-PV 1779/4 and 11384 (Fig. 13.12-13.13) the sulcus is almost perpendicular to the midline and runs near the suture with the entoplastron, in specimens MPEF-PV 1779/3, 11364, 11365, $11366,11386 / 60,11389 / 90$ and /113 the sulcus runs diagonally from latero-anteriorly to mid-posteriorly and runs far away of the suture with the entoplastron (Fig. 13.14, 13.16).

Specimens MPEF-PV 11389/113 and 11365 (Fig. 13.1413.15) are the largest specimens of this new sample, while MPEF-PV 11364 is the smallest (Fig. 13.1-13.3). The carapacial length estimated for MPEF-PV 11389/113 or 11365 is between 20 and $23 \mathrm{~cm}$, while it is $12 \mathrm{~cm}$ for MPEF-PV 11364.

Comments. As it is evident by the specimens reported herein, as well as previously published specimens, $H$. casamayorensis is one of the best-known turtle species from Chubut and Argentina, known from quite rich material. In the area of Cañadón Hondo, the specimens of $H$. casamayorensis are among the most common and dispersed findings, indicating an important presence of this species in the Lutetian ecosystems of the area. The new materials reported and described herein help understanding better the intraspecific variation, and the presence of several morphological morphotypes in the material assigned to this species.

Systematics. Testudinata / Meiolaniformes / Meiolaniidae indet. (Fig. 14).
Referred material. MPEF-PV 11362, fragment of nuchal bone, proximal end of costal, distal end of right femur, indet. carapacial and plastral remains; MPEF-PV 11363, right bridge peripheral bone.

Horizon. Sarmiento Formation; Lutetian, middle Eocene.

Collection point. Cañadón Hondo area, near Rocas Gemelas, Chubut Province, Argentina (\#158 in Fig. 2, Suppl. Table).

Collectors. M. S. de la Fuente, I. Maniel, D. Pol, P. Puerta, J. Sterli (2010, 2011).

Description. All reported specimens are poorly preserved providing limited information. The most outstanding remains are the partial nuchal bone (Fig. 14) and the distal end of a femur. The fragment of the nuchal bone shows that there was some kind of emargination, however, we cannot determine how deep it was (Fig. 14). The nuchal bone has an anterior protrusion where the cervical scute is present (Fig. 14). The cervical scute is not completely preserved, however, we can estimate it was longer than wide (Fig. 14.1). No further description of the nuchal is possible. Regarding the distal end of the femur (not figured), the condyles for the articulation with the tibia and fibula are preserved, however, the bone is damaged in that area preventing any further description.

Comments. Based on the size, lack of particular ornamentation, the presence of a considerable nuchal notch, and the presence of a protruding cervical scute, we can exclude a chelid identification for this specimen. Most probably, it belonged to a meiolaniform turtle, and Meiolaniidae in

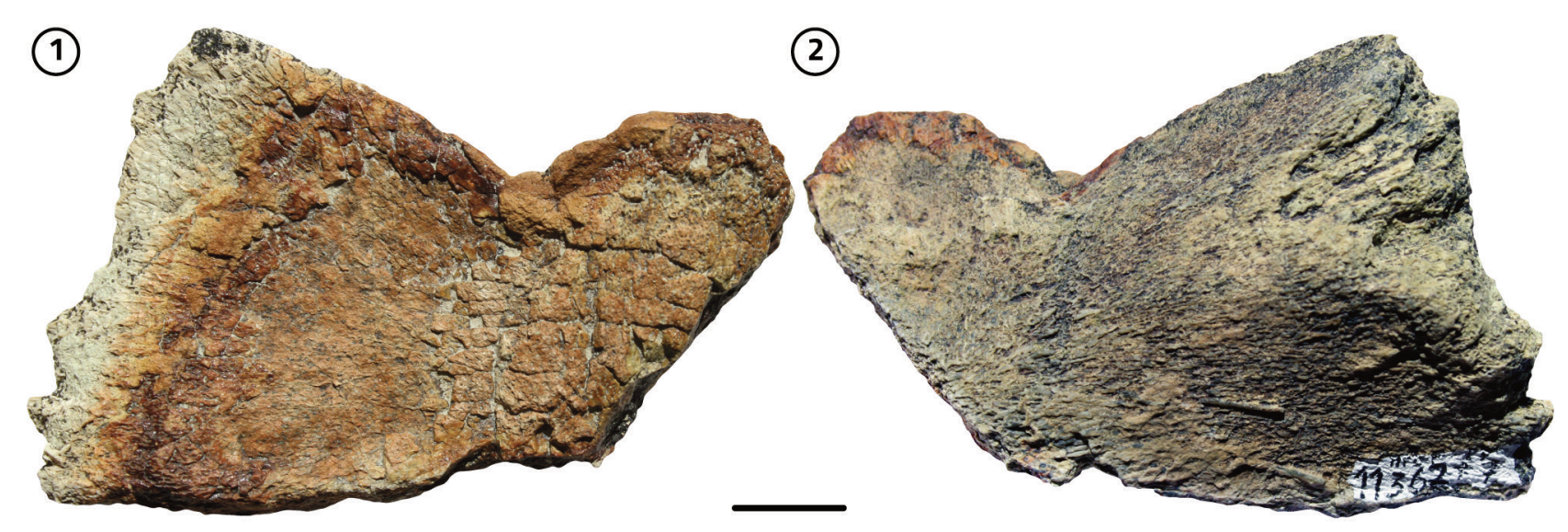

Figure 14. Turtle fossils from the Cañadón Hondo area, Eocene (Lutetian), Sarmiento Formation. Meiolaniidae gen. et sp. indet., MPEF-PV 11362. 1-2, nuchal in 1 , dorsal and 2 , visceral views. Scale bar $=1 \mathrm{~cm}$. 
particular, which are the representatives of this clade in the Eocene of Chubut. Two species of meiolaniids are known from Cañadón Hondo area, Niolamia argentina (specimen AMNH 3161, originally named as Crossochelys corniger by Simpson, 1937) and Gaffneylania auricularis. As none of the named species has postcranial remains comparable to those presented here, we cannot assign the new remains to any of them. That is the reason why we recognize the new remains as Meiolaniidae gen. et sp. indet.

\section{El Pajarito}

Systematics. Testudinata / Testudines indet. (Fig. 15).

Referred material. MPEF-PV 11371, part of costal 1, bridge peripheral, hyo/hypoplastron, and several indet. shell remains (Fig. 15.1-15.2); MPEF-PV 11372, costal bone (probably costal 8), fragment of the plastron, and four indet. shell remains (Fig. 15.3-15.4); MPEF-PV 11373, left hypoplastron (Fig. 15.5-15.6).

Horizon. Las Flores Formation; Ypresian-Lutetian, Eocene. Collection point. Cocotorta, near Paso de Indios, Chubut Province, Argentina (\#176 in Fig. 2, Suppl. Table).

Collectors. M. E. Pérez, P. Puerta, and E. Vlachos (2017).

Description. The few remains found in the broader area of El Pajarito represent fragmentary, transported, eroded and poorly preserved shell remains (Fig. 15). The plates from Cocotorta collection point (\#176 in Fig. 2) show no ornamentation (Fig. 15.1, 15.3, 15.5), however, we cannot as- sure this was the original aspect of the plates because they are highly eroded and the ornamentation could have been lost during taphonomic processes. Unfortunately due to the preservation of the shell remains, little anatomical information can be described. Costal 1 (MPEF-PV 11371) shows that the axillary buttress entered this costal (Fig. 15.2). A fragment of a presumably costal 8 (MPEF-PV 11372) is preserved. In dorsal view, this plate was partially covered by vertebrals 4 and 5 and pleural 4 (Fig. 15.3). In the hypoplastron (MPEF-PV 11373), part of the abdomino-femoral sulcus is preserved (Fig. 15.5).

Comments. The contact of the axillary buttress with costal 1 is reported in several groups of turtles (e.g., pleurodires, baenids, some testudinids, emydids). From those groups, only pleurodires and testudinids are recorded in Patagonia, consequently, these remains could belong to some of those clades. The importance of these fragmentary remains is that they document the presence of turtles in a previously unknown region in the central part of Chubut.

\section{Right margin of the Río Chico river}

Systematics. Testudinata / Testudines / Cryptodira / Testudinoidea / cf. Testudinidae indet. (Fig. 16).

Referred material. CPBA-V Nº 14180, various shell remains (Fig. 16).

Horizon. The exact location of the collection and the horizon is not known (\#173 in Fig. 2, Suppl. Table). The accom-

\section{(1)}

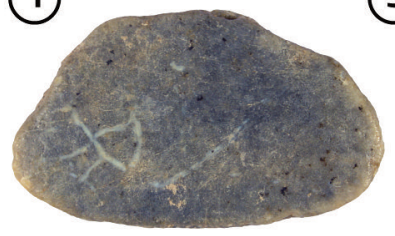

(2)

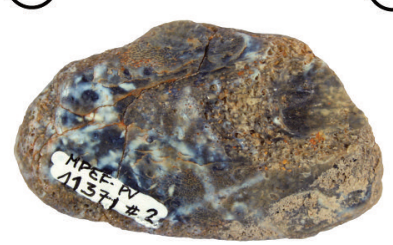

(3)

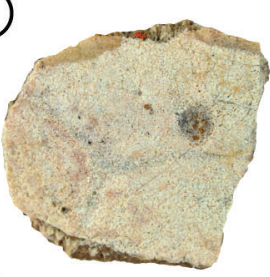

(5)

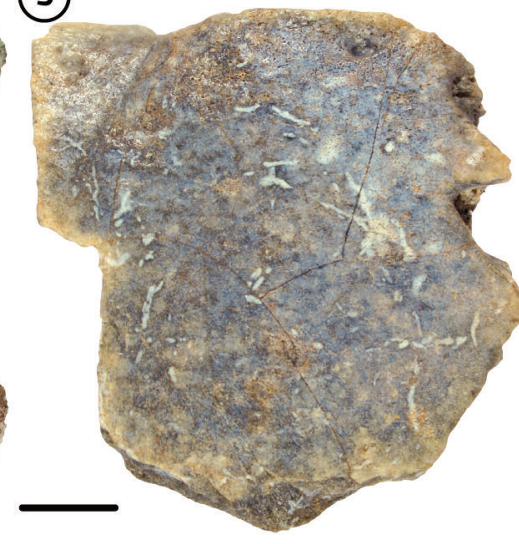

(6)

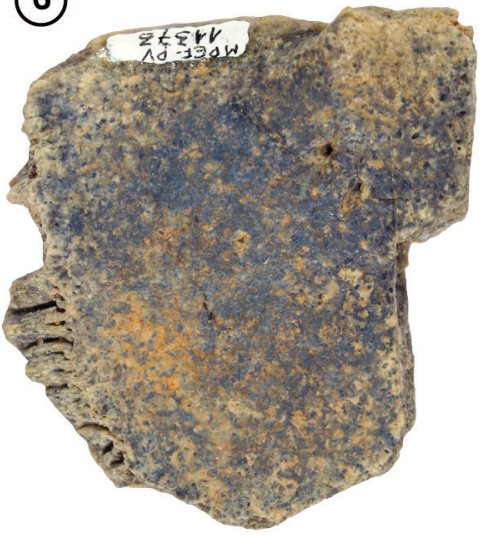

Figure 15. Turtle fossils from the El Pajarito area, Ypresian-Lutetian, Las Flores Formation. Testudines indet. 1-2, MPEF-PV 11371/2, ?right costal 1 in 1, dorsal and 2, visceral views; 3-4, MPEF-PV 11372/1, left costal 8 in 3, dorsal and 4, visceral views; 5-6, MPEF-PV 11373, right hypoplastron in 5, dorsal and 6, ventral views. Scale bar= $1 \mathrm{~cm}$. 
panying label information states that the specimens have been collected in the 'Cañadón Hondo Formation', and that they have an 'early Eocene' age. See Comments for further information.

Collection point. Right margin of Río Chico river, Chubut Province, Argentina; not to be confused with the homonymous Río Chico at the NW part of the Chubut Province.

Collector. Unknown.

Description. There is not much anatomical information on the specimens of this collection, but the majority of the plates have the typical ornamentation of the testudinids, with these parallel and deep growth lines (Fig. 16). One plate in particular could represent a partial costal plate showing the alternating pattern of Testudinidae (Fig. 16.1-16.2). Another could represent a peripheral showing a good coincidence between costo-peripheral sutures and pleuro-marginal sulci (Fig. 16.9-16.10). Based also on the uncertainty surrounding the provenance and age of the specimens, we provisionally identify them as cf. Testudinidae indet.

Comments. We have decided to include and bring into attention these specimens because of the implications of the information figured in the accompanying label. The exact provenance of the specimens is not known. Assuming that the locality information is correct and that the specimens come from the, previously-called, Cañadón Hondo Formation on the right margin of the Río Chico, then this area confidently corresponds to the area defined by the localities \#150-172 herein: the 'classic' Cañadón Hondo area. Up to now, fossils of turtles in this area belonged to either Chelidae or Meiolaniformes. The nearest testudinids are known from Cabeza Blanca \#179 (see below). Therefore, this conspicuous collection in the CPBA raises the possibility of testudinids in Cañadón Hondo. Based on the most up-to-date information, the outcrops in the Cañadón Hondo area cover
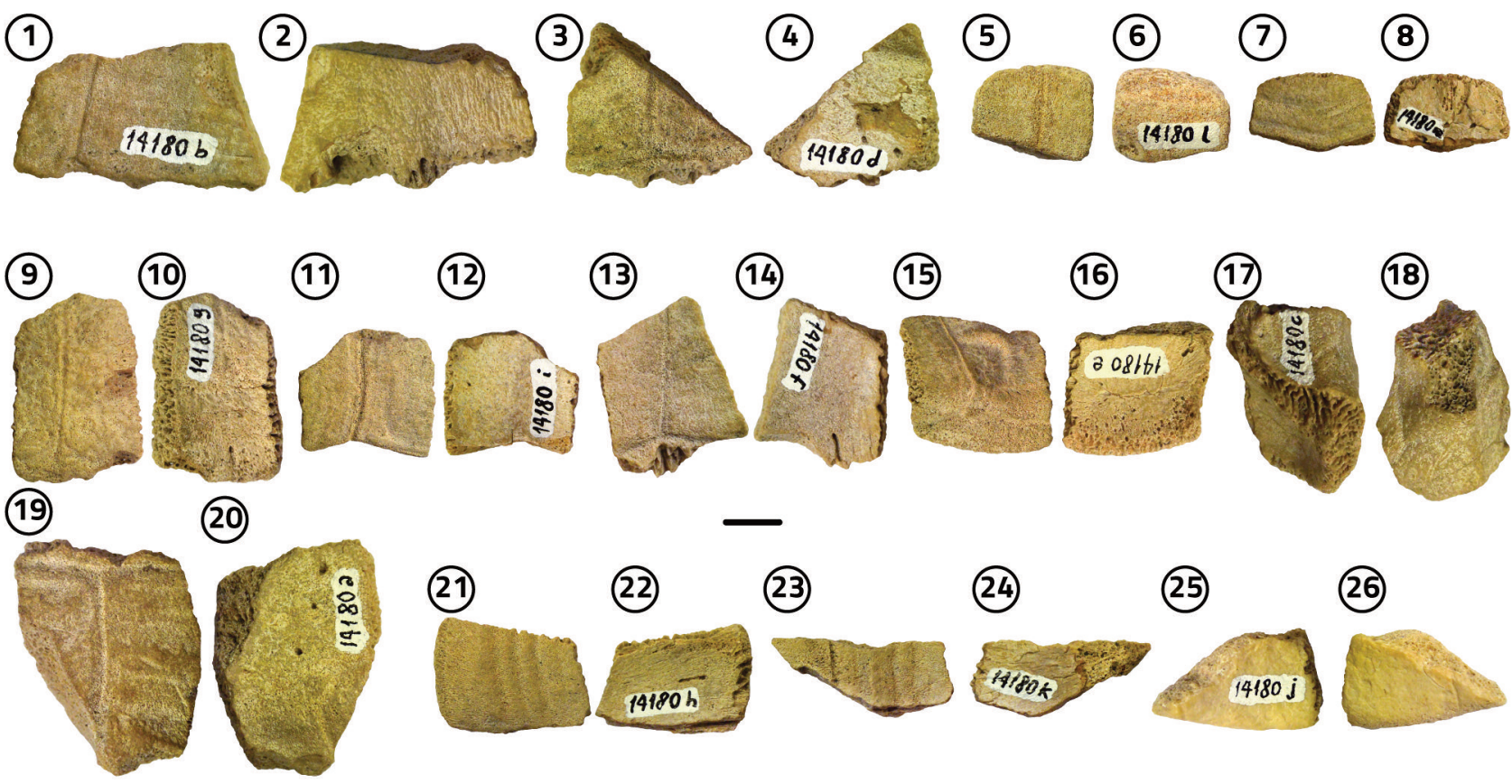

Figure 16. Turtle fossils Río Chico, Age and Formation indet. cf. Testudinidae indet. CPBA 14180. 1-2, CPBA 14180b, costal fragment in 1, dorsal and 2, visceral views; 3-4, CPBA 14180d, costal fragment in 3, dorsal and 4, visceral views; 5-6, CPBA 14180l, costal fragment in 5, dorsal and 6, visceral views; 7-8, CPBA 14180, costal fragment in 7, dorsal and 8, visceral views; 9-10, CPBA 14180g, peripheral in 9, dorsal and 10, visceral views; 11-12, CPBA 14180i, peripheral fragment 11, dorsal and 12, visceral views; 13-14, CPBA 14180f, peripheral fragment in 13, dorsal and 14, visceral views; 15-16, CPBA 14180e, peripheral in 15, dorsal and 16, visceral views; 17-18, CPBA 14180c, peripheral in 17, dorsal and 18, visceral views; 19-20, CPBA 14180a, peripheral fragment in 19, dorsal and 20, visceral views; 21-22, CPBA 14180h, plastron fragment in 21, dorsal and 22, visceral views; 23-24, CPBA 14180k, plastron fragment in 23, dorsal and 24, visceral views; 25-26, CPBA 14180j, plastron fragment in 25, dorsal and 26, visceral views. Scale bar $=1 \mathrm{~cm}$. 
the timespan of the middle Eocene-late Oligocene. Further sampling with precise stratigraphic information should corroborate the potential of these CPBA specimens.

\section{Cabeza Blanca}

Systematics. Testudinata / Testudines indet. (Fig. 17.1-17.3). Referred material. MACN no number. Costal bone and indet. fragments.

Horizon. Precise horizon unknown; Rupelian, Deseadan SALMA, Late Oligocene.

Collection point. Cabeza Blanca, Chubut Province, Argentina (\#179 in Fig. 2, Suppl. Table).

Collector. Unknown.

Description. All the elements attributed to Testudines indet. from Cabeza Blanca are thin plates with no ornamentation. A paired costal is preserved (Fig. 17.1). This plate is covered partially by a vertebral and two pleural scutes (Fig. 17.1). Two more fragments are here identified as putative plastral fragments (Fig. 17.2-17.3).
Comments. The recognition of Testudines indet. in Cabeza Blanca increases the alpha turtle diversity in the locality, previously containing only the testudinid Chelonoidis sp. (see below). Unfortunately, both taxa are recognized based on fragmentary remains. For sure, more complete specimens will bring more anatomical information that could help to refine their taxonomic identification. Turtle specimens coming from the Oligocene are very important because there is a faunal turnover observed between the Lutetian turtle fauna found in Cañadón Hondo area characterized by chelids and meiolaniids and the Miocene continental turtle fauna characterized by testudinids.

Systematics. Testudinata / Testudines / Cryptodira / Durocryptodira / Testudinoidea / Testudinidae / Geochelonini / Chelonoidis sp. (Fig. 17.4-17.8).

Referred material. MACN no number. Epiplastron fragment and indeterminate shell fragments.

Horizon. Precise horizon unknown; Rupelian, Deseadan
(1)

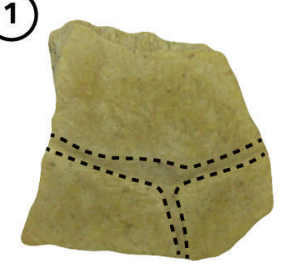

(2)

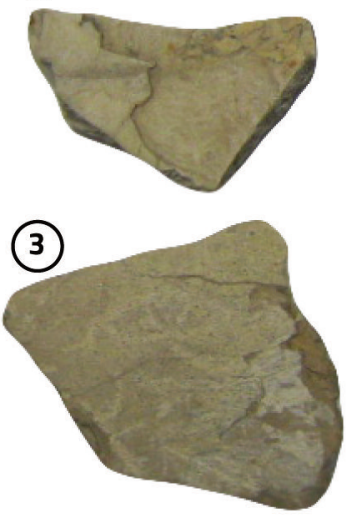

(4)
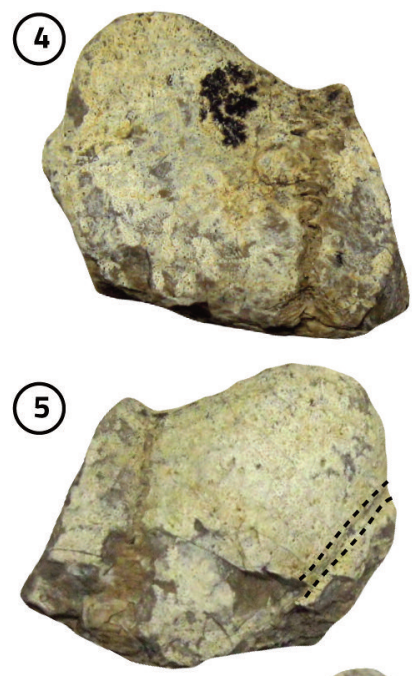

(6)

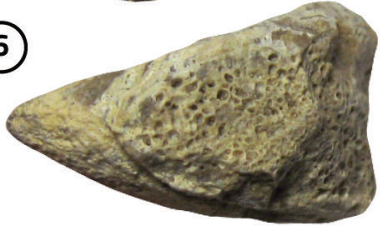

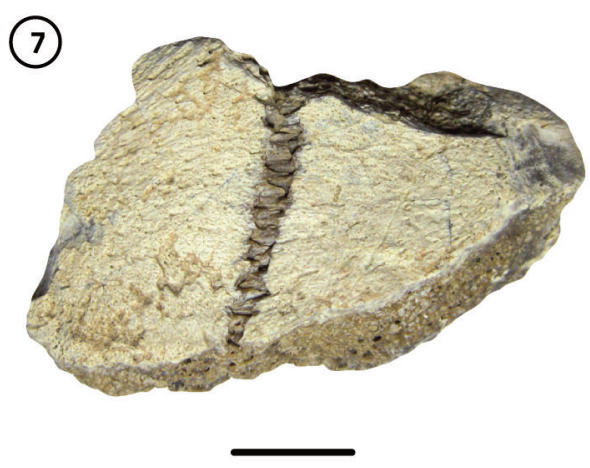

(8)

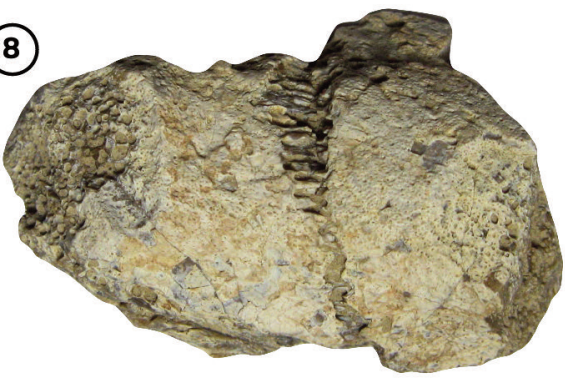

Figure 17. Turtle fossils from Cabeza Blanca, late Oligocene (Rupelian, Deseadan SALMA). MACN s/n. 1-3, Testudines indet. 1, costal bone in dorsal view; 2-3, putative plastral fragments; 4-8, Chelonoidis sp. 4-6, left epiplastron and a fragment of the right one in 4, visceral; 5, ventral; 6, and lateral views; $7-\mathbf{8}$, shell fragment in $\mathbf{7}$, dorsal and $\mathbf{8}$, visceral views. Scale bar $=1 \mathrm{~cm}$. 
SALMA, Late Oligocene.

Collection point. Cabeza Blanca, Chubut Province, Argentina (\#179 in Fig. 2, Suppl. Table).

Collector. Unknown.

Description. From the referred specimens (Fig. 17), the only one that contains some valuable anatomical information is the epiplastron (Fig. 17.4-17.6). It comprises most of the anterior part of the left epiplastron and a small part of the right epiplastron. It is thick, indicating the presence of an epiplastral lip; its dorsal surface is relatively flat (Fig. 17.6). There is a narrow, wide, and rounded notch, with weaklydeveloped and rounded epiplastral projections (Fig. 17.417.5). Part of the gularo-humeral sulcus is visible, allowing the reconstruction of narrow gular scutes (Fig. 17.5). Overall, the morphology of the epiplastron is consistent with that of a testudinid species and Chelonoidis in particular. An epiplastral lip with straight dorsal surface is noted in Chelonoidis gringorum, but as this is also the case in many other testudinid species we refrain from reaching a specificlevel identification for this specimen. The remaining specimens from Cabeza Blanca do not bring more information and are consistent as well with the identification of Chelonoidis sp.

Comments. This occurrence of a Chelonoidis species in the late Oligocene of Chubut is the only pre-Neogene occurrence of this clade in Argentina (see also de la Fuente et al., 2018). All other occurrences in Chubut come from the earlymiddle Miocene (new material herein, de la Fuente et al., 2018 and references therein). Also, the Cabeza Blanca tortoise is arguably the southernmost occurrence of a true tortoise in South America, which makes it at the same time the southernmost occurrence of the family in the world. However, this might change in the future as we are currently evaluating some scarce material from further south in the Santa Cruz Province that could pertain to testudinids as well. These include unpublished occurrences from the MLP collection and the mentioned occurrence from Pampa del Castillo by de Broin and de la Fuente (1993; MACN material).

\section{Bryn Gwyn Geopark}

Systematics. Testudinata / Testudines / Cryptodira / Testudinoidea / Testudinidae / Geochelonini / Chelonoidis / Chelonoidis gringorum (Figs. 18-19).

Referred material. MPEF-PV 1376, various carapace and plastron fragments, a pelvic fragment, possibly of a single individual; MPEF-PV 1410, shell fragments of at least two different individuals, including a partial anterior plastral lobe (19.4-19.5); MPEF-PV 2543, one individual with 40 preserved shell bones (Figs. 18.1-18.5, 19.1-19.3); MPEF-PV 2543-1, almost complete plastron; MPEF-PV 2543-2, lateral fragment of a costal; MPEF-PV 2543-3, bridge peripheral fragment; MPEF-PV 2543-4, left hypoplastron fragment; MPEF-PV 2543-5/20, part of the posterior carapace, including neurals $6-7$, costals $4-6$ (left) and costal 6 (right, fragmented); MPEF-PV 2543-6/7, anterior border of the carapace including the nuchal, most of the first costals, right peripherals 1-3, and left peripherals 1-4; MPEF-PV 2453-8/14/15, right peripherals 7-9; MPEF-PV 2543$10 / 19$, association of the distal parts of two consecutive bridge peripherals; MPEF-PV 2453-11/12, 2543-9, medial fragment of a costal; MPEF-PV 2453-13, distal part of a bridge peripheral; left peripherals 7-9; MPEF-PV 2543-16, association of the lateral parts of two consecutive costals; MPEF-PV 2543-17, right peripheral 11; MPEF-PV 2543-18, medial fragment of a costal; MPEF-PV 2544, one individual represented by four plates of the plastron: MPEF-PV 25441, hyo/hypoplastron fragment; MPEF-PV 2544-2, right hyoplastron fragment; MPEF-PV 2544-3, left hyoplastron fragment; MPEF-PV 2544-4, right xiphiplastron fragment; MPEF-PV 2545, one small-sized (juvenile) individual represented by six plates of the carapace; MPEF-PV 2545-1, ?costal indet.; MPEF-PV 2545-2, distal part of a bridge peripheral; MPEF-PV 2545-3, right peripherals 7-8; MPEFPV 2545-4, anterior peripheral; MPEF-PV 2545-5, costal fragment; MPEF-PV 2545-6, distal part of a bridge peripheral.

Horizon. Sarmiento Formation, early Miocene.

Collection point. Bryn Gwyn Geopark, Gaiman, Chubut Province, Argentina. The exact collection spot of specimens MPEF-PV 1376 and MPEF-PV 1410 is unknown. Specimens MPEF-PV 2543-2545 were collected in 1990 at the collection spot \#186 (Fig. 2, Suppl. Table).

Collectors. M. T. Dozo and M. A. Cozzuol (1990).

Description. The overall morphology of the specimens is consistent with a single testudinid taxon, based on the good coincidence between the costo-peripheral and pleuro-marginal sulci (in MPEF-PV 1376, 2543, 2544), the alternating 
pattern of the neural plates (in MPEF-PV 2543), the presence of a well-developed epiplastral lip (in MPEF-PV 1376, 2543), and short pectoral scutes (shorter than half of the medial hypoplastral length; in MPEF-PV 2543) (Figs. 1819). The morphology of these new specimens is consistent with Ch. gringorum as described in the literature (e.g., de la Fuente, 1994; Oriozabala et al., 2018). In particular, the absence of the cervical scute, oval outline of the shell, the lack of contact between the femoral and inguinal scutes in ventral view (MPEF-PV 2543), and the lack of keels in the peripheral plates scute (in MPEF-PV 1376, 2543-2545) (Figs. 18-19). As the morphology of this species has been recently presented in detail (e.g., de la Fuente, 1994; Oriozabala et al., 2018), we do not present extensive descriptions. Instead, we focus on the set of variable characters, as described in Oriozabala et al. (2018). MPEF-PV 2543 presents a well-defined, deep, and angular nuchal notch, which affects only the nuchal plate. Its depth is in between the extensive nuchal notch of MPEF-PV 1049 (see de la Fuente,
1994, figs. 6, 7) and the less-extensive of the holotype AMNH 3366 (Simpson, 1942, fig. 1), so lies within the variability of the species. The sulcus between vertebral 3 and 4 crosses neural 5 (MPEF-PV 2543) as in the majority of Ch. gringorum specimens (Fig. 18.3-18.4). Both preserved anterior plastral lobes (MPEF-PV 1410, MPEF-PV 2543) show a well-developed gular protrusion with an associated gular notch, creating two extensive and thickened epiplastral extremities (Fig. 19). Those of MPEF-PV 1410 exhibit two smaller notches on each extremity forming a forked morphology (Fig. 19.4-19.5). The presence of such extensive epiplastral extremities is usually associated with male individuals in tortoises (see also Oriozabala et al., 2018). This is true in our referred specimens as well, as the MPEF-PV 2543 plastron shows a well-marked hyo/hypoplastral concavity of a male individual (see also Oriozabala et al., 2018) (Fig. 19.1, 19.2). The dorsal surface of the epiplastral lip is flat (MPEF-PV 2543) to flat-to-concave (MPEF-PV 1410). In both cases, the gular scutes touch the anterior border of
(1)

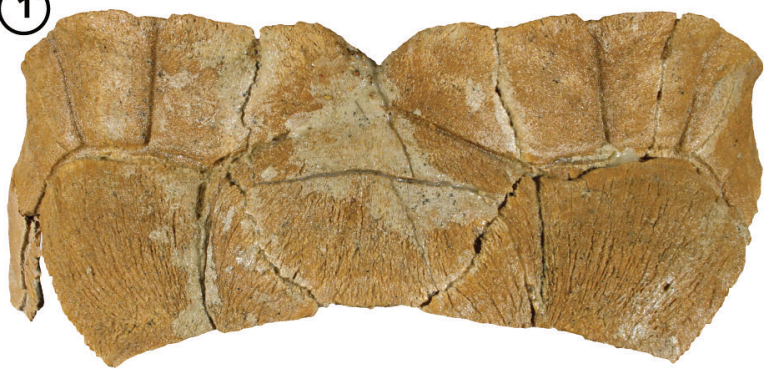

(3)

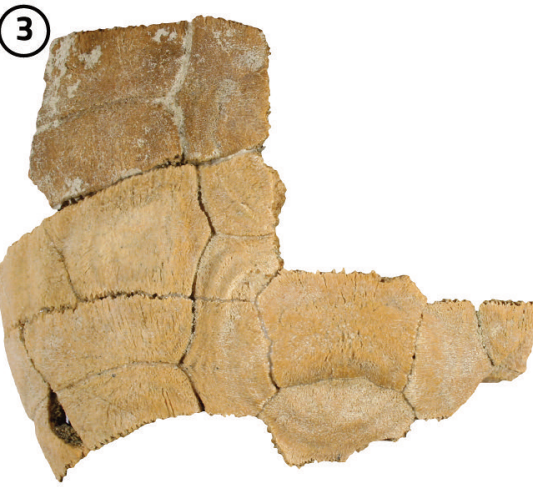

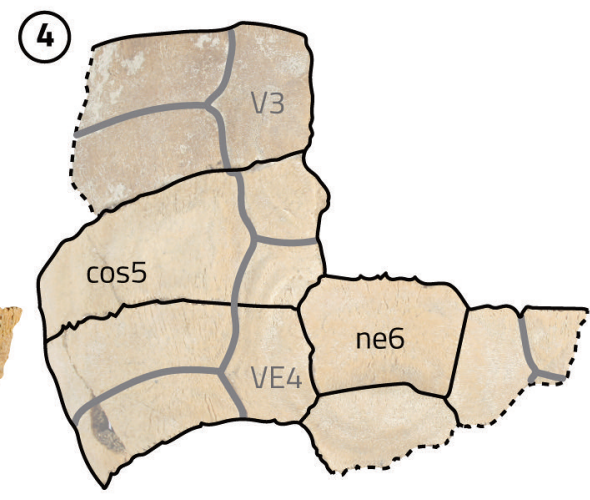

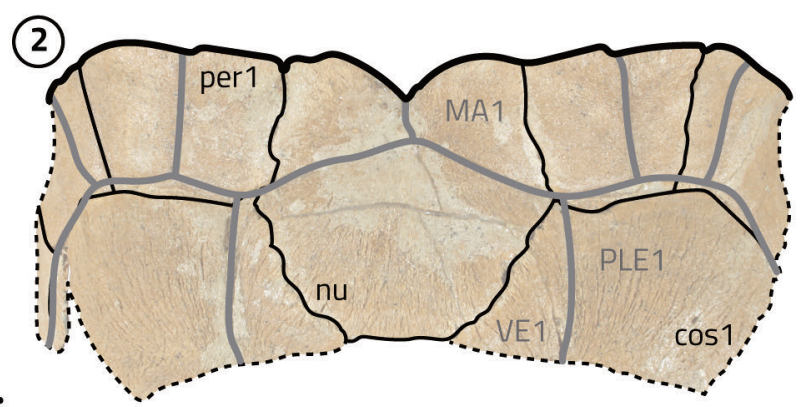

(5)

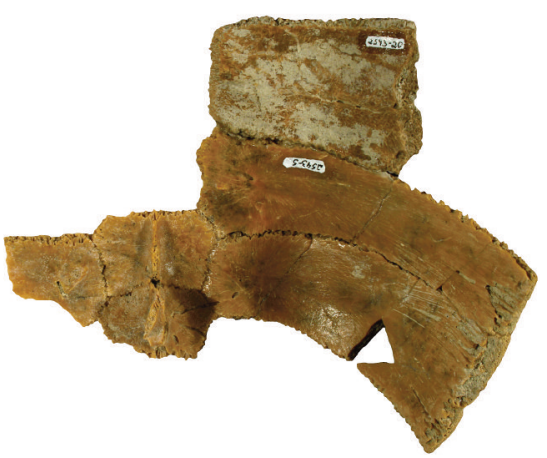

Figure 18. Turtle fossils from Bryn Gwyn Geopark, early Miocene, Sarmiento Formation. Chelonoidis gringorum. 1-5, MPEF-PV 2543; 1-2, anterior portion of the carapace in dorsal view; $3-5$, medial portion of the carapace in $3-4$, dorsal and 5 , visceral views. Scale bar= $1 \mathrm{~cm}$. Abbreviations (bony plates with small letters; horny scutes with capital letters): cos, costal; MA, marginal; ne, neural; nu, nuchal; per, peripheral; PLE, pleural; VE, vertebral. 
(1)
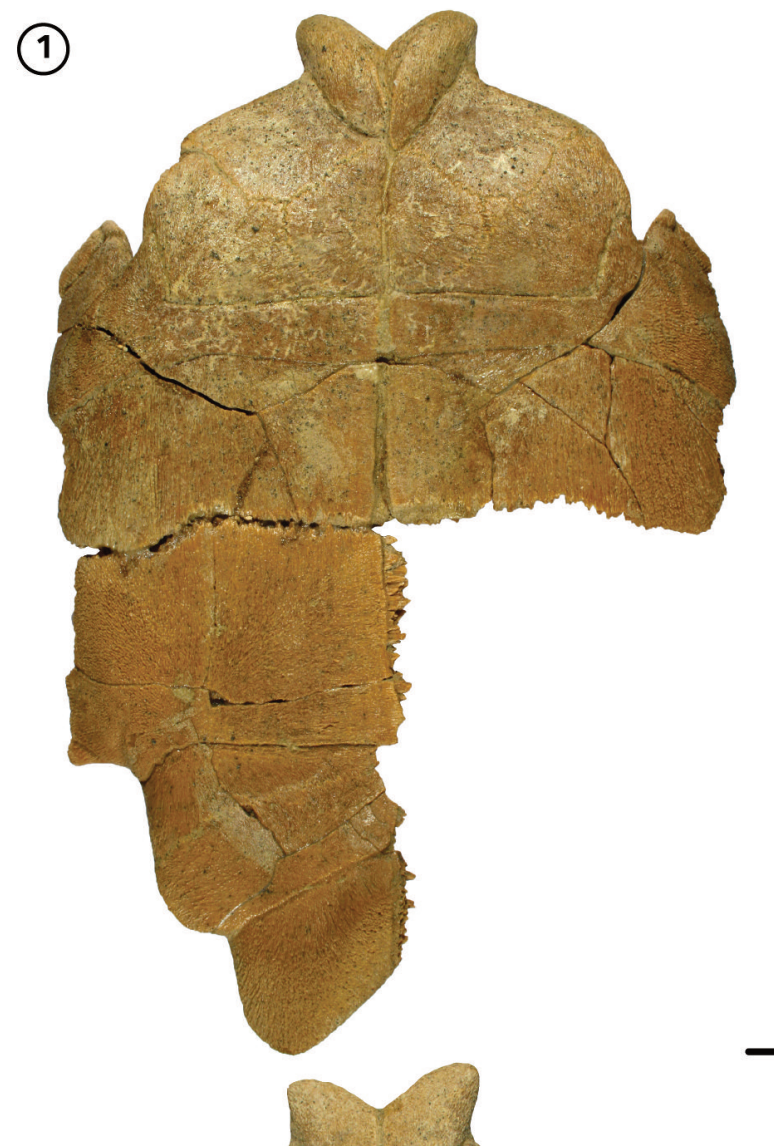

(3)

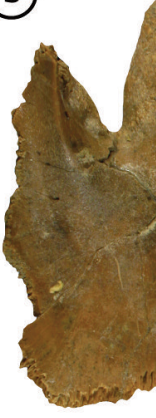

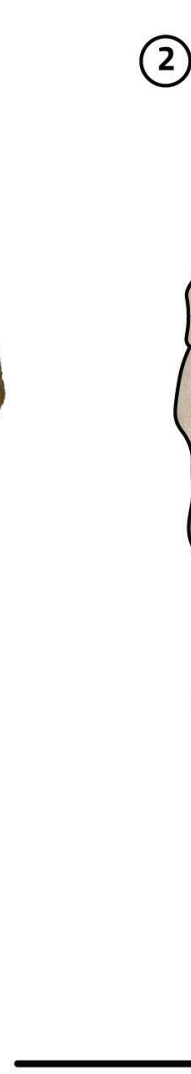

(2)
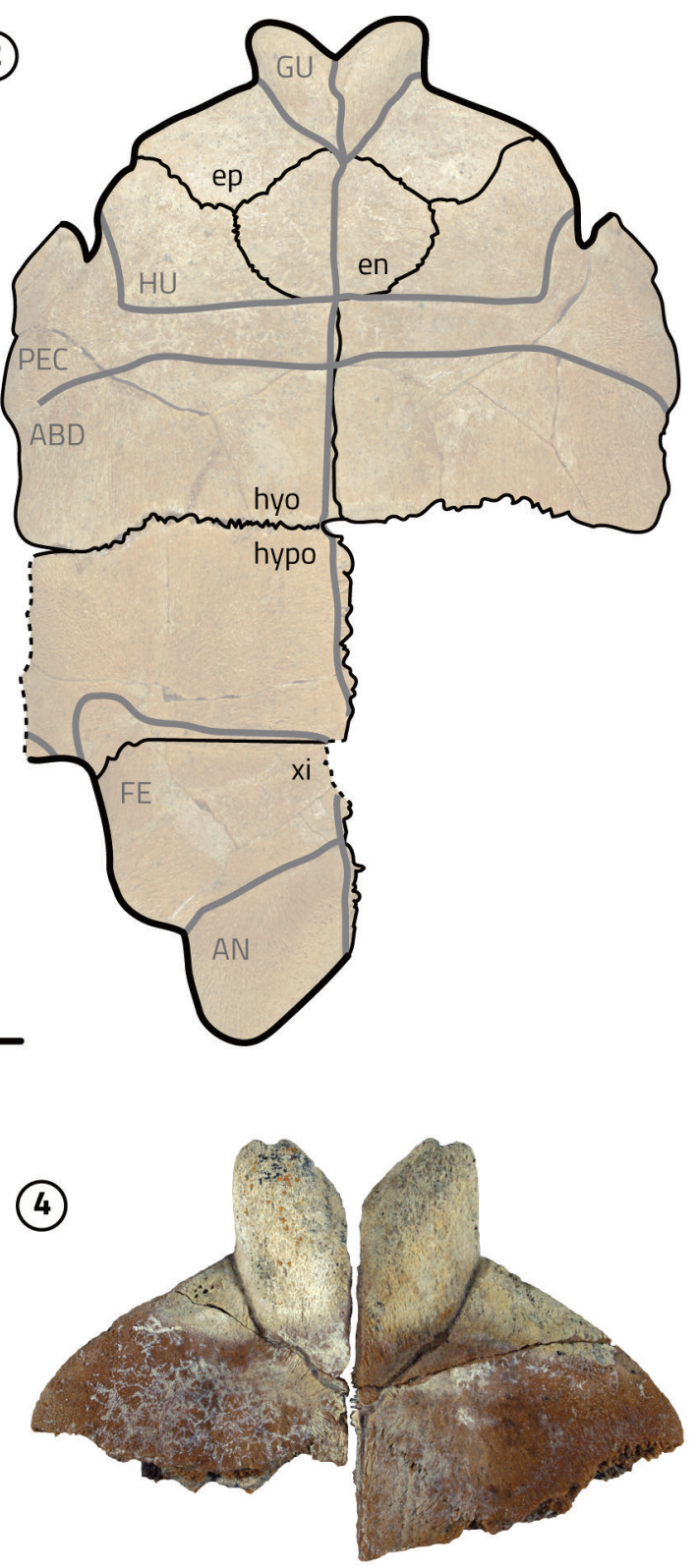

(5)

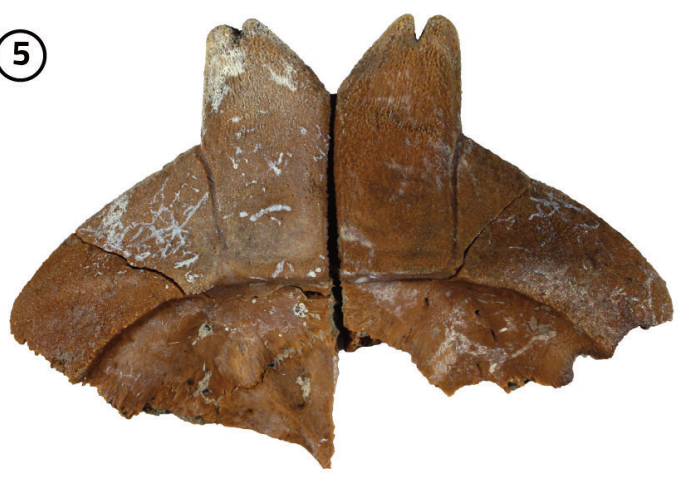

Figure 19. Turtle fossils from Bryn Gwyn Geopark, early Miocene, Sarmiento Formation. Chelonoidis gringorum. 1-3, MPEF-PV 2543. 1-2, ventral views; 3, visceral view; 4-5, MPEF-PV 1410, anterior portion of the plastron in 4, ventral and 5, visceral views. Scale bar= $5 \mathrm{~cm}$. Abbreviations (bony plates with small letters; horny scutes with capital letters): ABD, abdominal; AN, anal; en, entoplastron; ep, epiplastron; FE, femoral; GU, gular; HU, humeral; hyo, hyoplastron; hypo, hypoplastron; PEC, pectoral; xi, xiphiplastron. 
the entoplastron (Fig. 19.1-19.2, 19.4). In MPEF-PV 2543, the humero-pectoral sulcus coincides medially with the posterior end of the entoplastron (Fig. 19.1-19.2). MPEFPV 1376, MPEF-PV 2543, and MPEF-PV 2544 show welldeveloped xiphiplastral extremities, which are flattened and associated with a deep and angular anal notch (Fig. 19.119.3); these are further morphologies related to male individuals and sexual dimorphism in this species (see also Oriozabala et al., 2018).

Comments. The terrestrial deposits of the Trelew Member (Sarmiento Formation; early Miocene) that flourish on the margins of Chubut river in the Bryn Gwyn - Gaiman - Dolavon area are quite rich in tortoise fossils. In this area, apparently, J. Hernández discovered the holotype of Ch. gringorum (AMNH 3366) and gave it to G. G. Simpson during the Scarritt Expedition (Simpson, 1942). Especially in the area included today in the Bryn Gwyn Geopark, tortoise fossils are frequent findings. Isolated plates are found all over the place in almost every search, and often more complete fossils are found in situ. Apparently, these tortoises are encountered more frequently in the sandy parts of Trelew Member (being more complete and better preserved), but some specimens have also been found in the lower nodular parts; these are less frequent and usually poorly preserved. The known and referred specimens of Ch. gringorum (besides those herein, see also Simpson, 1942; de la Fuente, 1997; Oriozabala et al., 2018 and references therein) present an interesting morphological variability. Basically, the known specimens present two morphotypes, one with more basal character states and another with more derived ones (within derived Geochelonini), especially in the neural pattern and gular length compared to the entoplastron. Once the preparation and study of new specimens from and near El Camino (\#187-188, Fig. 2, Suppl. Table) are completed, we will evaluate this variability in a cladistic context. The specimens referred herein are consistent with the more derived morphotype of the Ch. gringorum complex.

Systematics. Testudinata / Testudines / Cryptodira / Chelonioidea / Pan-Dermochelyidae indet. (Fig. 20).

Referred material. MPEF-PV 11360, two ossicles, one complete (MPEF-PV 11360A) and one incomplete (MPEF-PV 11360B).

Horizon. Gaiman Formation, early Miocene.

Collection point. Near Bryn Gwyn Geopark, Chubut Province, Argentina (\#181 in Fig. 2, Suppl. Table).

Collectors. M. Viglino and J. Cuitiño (2017).

Description. The complete ossicle (MPEF-PV 11360A) has an irregular shape (Fig. 20.1, 20.3), while the shape of the incomplete one (MPEF-PV 11360B) is not possible to assess $(20.4$, 20.6). Both are flat, thick elements (around $1 \mathrm{~cm}$ ) (Fig. 20.2, 20.5), with no ornamentation (Fig. 20). They are similar in morphology to those ossicles also found in Bryn Gwyn described by de la Fuente and Vucetich (1998).

Comments. The presence of these irregular ossicles allows a clear identification of these specimens as members of
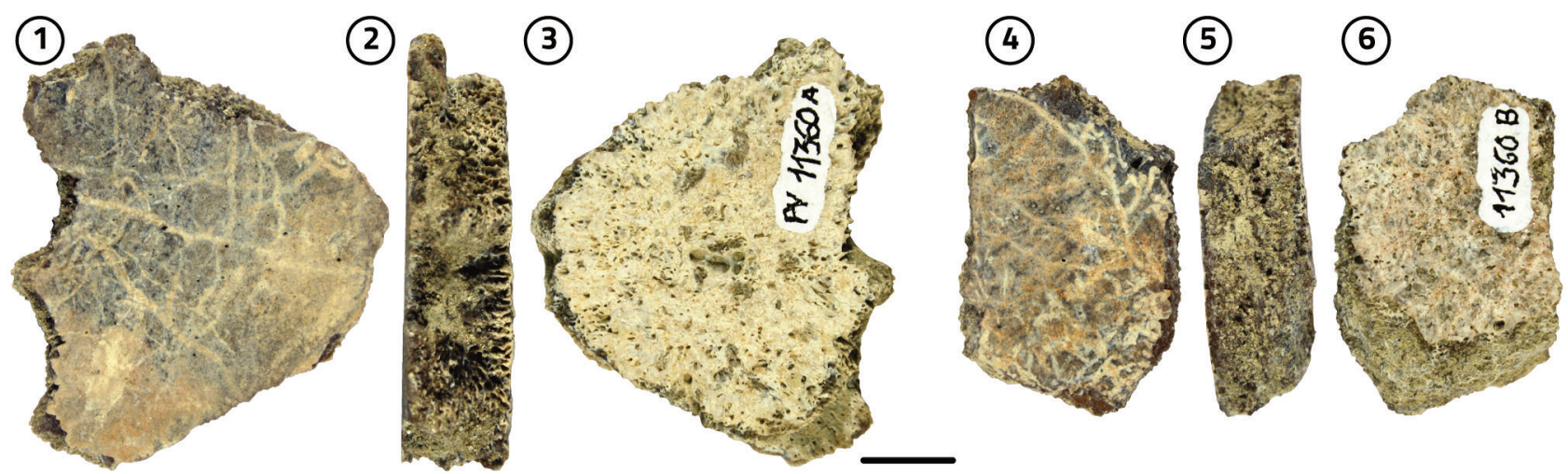

Figure 20. Turtle fossils from near Bryn Gwyn Geopark, early Miocene, Gaiman Formation. Pan-Dermochelyidae indet. MPEF-PV 11360. 1-3, MPEF-PV 11360A, ossicle in 1, dorsal; 2, lateral; 3, and visceral views; 4-6, MPEF-PV 11360B, ossicle in 4, dorsal; 5, lateral; 6, and visceral views. Scale bar $=1 \mathrm{~cm}$. 
the Pan-Dermochelyidae lineage. In particular, the thickness of these ossicles is reminiscent of the morphology of Psephophorus or Natemys, but more complete specimens are needed for a more accurate identification. Although this specimen is fragmentary, it is relevant because it increases the number of occurrences of this taxon in Patagonia.

\section{La Gloria}

Systematics. Testudinata / Testudines / Cryptodira / Testudinoidea / Testudinidae / Geochelonini / Chelonoidis / Chelonoidis gringorum (Fig. 21).

Referred material. La Gloria-5 locality: MPEF-PV 11446, fragments of the shell of a single tortoise individual; La Gloria-10 locality: MPEF-PV 11447, an almost complete plastron with associated carapace plates of a single female individual (Fig. 21); La Gloria-11 locality: MPEF-PV 11448, fragments of a robust tortoise, including a partial neural, two peripherals, a possible peripheral 11 and pygal fragment, and a plastral fragment.

Horizon. Collón Curá Formation, upper part; SerravallianTortonian, late Miocene.

Collection points. La Gloria-5, La Gloria-10 y La Gloria-11, near Paso del Sapo, Chubut Province, Argentina (\#219-221 in Fig. 2, Suppl. Table).

Collector. M. E. Pérez (2018).

Description. The most informative specimen is MPEF-PV 11447 from La Gloria-10 (Fig. 21). This plastron belongs to a testudinid tortoise based on the presence of a well-developed epiplastral lip, and the short pectoral scutes, which are shorter than half of the medial hyoplastral suture (Fig. 21.1-21.2). The anatomy is consistent with the diagnosis of the Chelonoidis gringorum complex, based on the dorsally
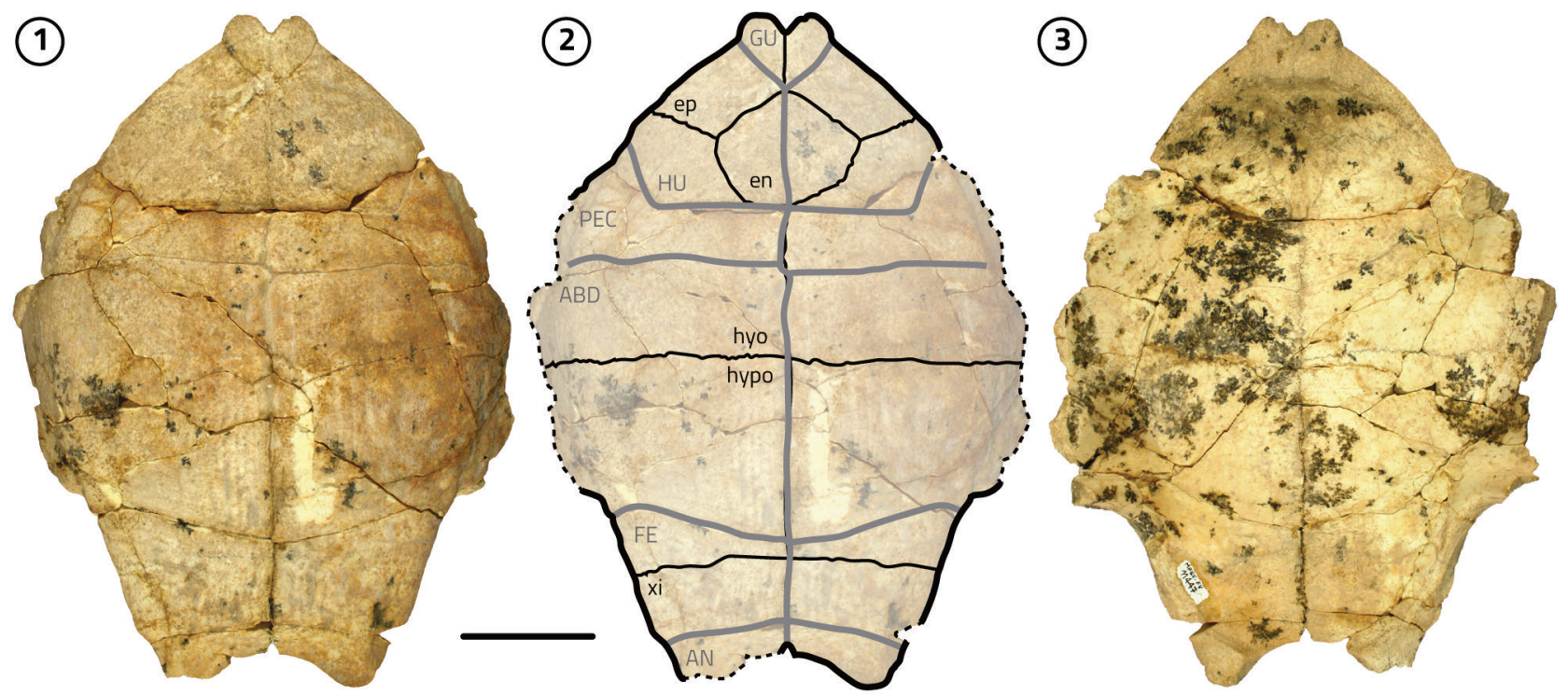

(4)

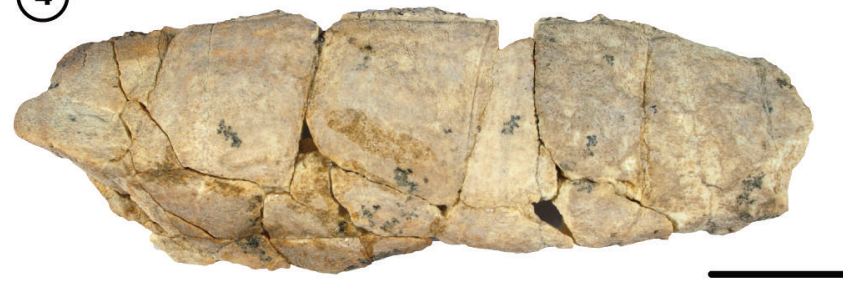

(5)

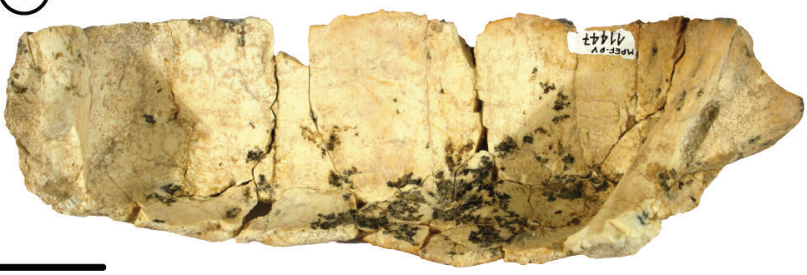

Figure 21. Turtle fossils from La Gloria, middle Miocene (Serravallian), Collón Curá Formation. Chelonoidis gringorum. MPEF-PV 11447. 1-2, plastron in ventral views; 3 , plastron in visceral view; 4, right bridge in lateral view; 5 , right bridge in medial view. Scale bars= $5 \mathrm{~cm}$. Abbreviations (bony plates with small letters; horny scutes with capital letters): ABD, abdominal; AN, anal; en, entoplastron; ep, epiplastron; FE, femoral; GU, gular; HU, humeral; hyo, hyoplastron; hypo, hypoplastron; PEC, pectoral; xi, xiphiplastron. 
straight-slightly-concave epiplastral lip, the gular scutes that do not cover the anterior part of the entoplastron, and the lack of contact between the femoral and inguinal scutes in ventral view (see Oriozabala et al., 2018 and references therein) (Fig. 21.1-21.2). The entoplastron is rhomboidal and symmetrical, being covered only by the humeral scutes (Fig. 21.1-21.2). Both the gularo-humeral and the humero-pectoral sulci touch, but do not cover, the anterior and posterior ends of the entoplastron, respectively (Fig. 21.1-21.2). The middle part of the plastron is relatively flat in its entire surface, indicating that this is a female individual (Fig. 21.1-21.3). This is further corroborated by the weakly-developed epiplastral projections, and the rounded xiphiplastral extremities (Fig. 21.1-21.3). The anal notch is wide, short, and rounded (Fig. 21.1-21.3). Besides this plastron, some peripheral plates of the bridge area are also preserved (Fig. 21.4-21.5). They present the typical morphology of this species.

The various shell fragments from La Gloria-11 (MPEFPV 11448; not figured) appear to belong to the same individual, which seems to have been quite robust and larger than the individual of La Gloria-10 (MPEF-PV 11447). The partial neural appears to have been a rectangular one, being crossed by an intervertebral sulcus (neural 3 or 5). A part of the carapacial border is identified as part of the left peripheral 11 and part of the pygal. Based on the preserved part we can estimate the presence of a posterior carapacial border that was curved ventrally, and that the marginals 12 were fused into a supracaudal.

The various shell fragments from La Gloria-5 (MPEF-PV 11446; not figured) also appear to correspond to a single individual, but the state of preservation is not so good to allow detailed observations. The identifiable parts include an association of left costals 7-8, a costal/peripheral association, isolated peripherals, and some fragments of appendicular elements (fragments of the pelvic girdle, a humerus, and other long bones).

Comments. The observed characters on the tortoises from La Gloria-5 and 11 allow attribution to Testudininae (coincidence between costo-peripheral sutures and pleuromarginal sulci, alternating costals, presence of a supracaudal). Although the diagnostic characters of Chelonoidis gringorum are not available for observation in the material of these two localities, the observed anatomy falls within the morphology of this species. Based on the geographical and temporal proximity, the specimens from La Gloria-5 and 11 are also attributed to Chelonoidis gringorum.

\section{DISCUSSION}

\section{Faunal Changes and Diversity}

The new information presented herein allows updating and further refining the scheme proposed in Vlachos et al. (2018). In that work, the authors demonstrated the changes in the composition of turtle faunas in South America for continental and marine turtles, and analyzed the changes in their diversity. Briefly, South American continental turtles can be grouped into three faunal phases: (1) the Pangean Phase (Late Triassic-Middle Jurassic), with basal non-testudine-testudinatans documenting the first transition to the aquatic habitats; (2) the Gondwanan Phase (Late JurassicEocene), with a diverse turtle fauna dominated by pleurodires and meiolaniformes which has been affected by the K/Pg extinction event; and (3) the South American Phase (Oligocene-present), with the extinction of non-testudine turtles and the appearance of continental cryptodires as injections of biodiversity (see Vlachos et al., 2018 and references therein). Chubut is the Argentine province where we can find fossil turtles from all three phases mentioned above. In this work, we present additional material that helps improving our knowledge about the temporal and geographical distribution of turtles in Chubut.

The fossil record of Chubut is crucial for understanding the K/Pg extinction event in southern South America, as well as the transition between the Pangean and Gondwana Phases and between the Gondwanan and South American Faunal Phases (Fig. 22). The majority of the known occurrences refer to representatives of the Gondwanan Phase, which sum up more than $81 \%$ of the known fossil occurrences of Chubut (Fig. 22). During the Gondwana Phase, Chubut documents the oldest records of the Pan-Chelidae lineage (e.g., Prochelidella cerrobarcinae, cf. Prochelidella sp. from Cerro Mesa) as well as of the meiolaniform lineage (e.g., Chubutemys copellor), highlighting its importance in a global context to understand the origin and early evolution of both clades.

Most of the occurrences of the Gondwanan Phase deal 
with the Late Cretaceous-Paleocene, which helps documenting the turtle faunal changes that took place during the $\mathrm{K} / \mathrm{Pg}$ transition. In terms of raw diversity, the number of sampled species remains the same in Chubut across the K/Pg boundary with at least four species (Fig. 22). The phylogenetic diversity, however, changes from estimated 10 clades in the Late Cretaceous to five in the Paleocene, dropping continuously until the three known clades in the Eocene (Fig. 22). These results are analogous to those we reported previously (Vlachos et al., 2018), indicating that
Chubutean turtles were significantly affected by the K/Pg extinction event. Chubut contains a fair share of the $\mathrm{K} / \mathrm{Pg}$ survivors in South America, with at least four species. Also, it seems that sampling in the Paleocene is quite good, compared to the Late Cretaceous where apparently, we have sampled less than half of the estimated taxa (Fig. 22). In the Late Cretaceous there is a big difference between the raw sampled diversity (four species; blue in Fig. 22) and the estimated phylogenetic diversity (10 species; orange in Fig. 23), which means that we have yet to find more than half

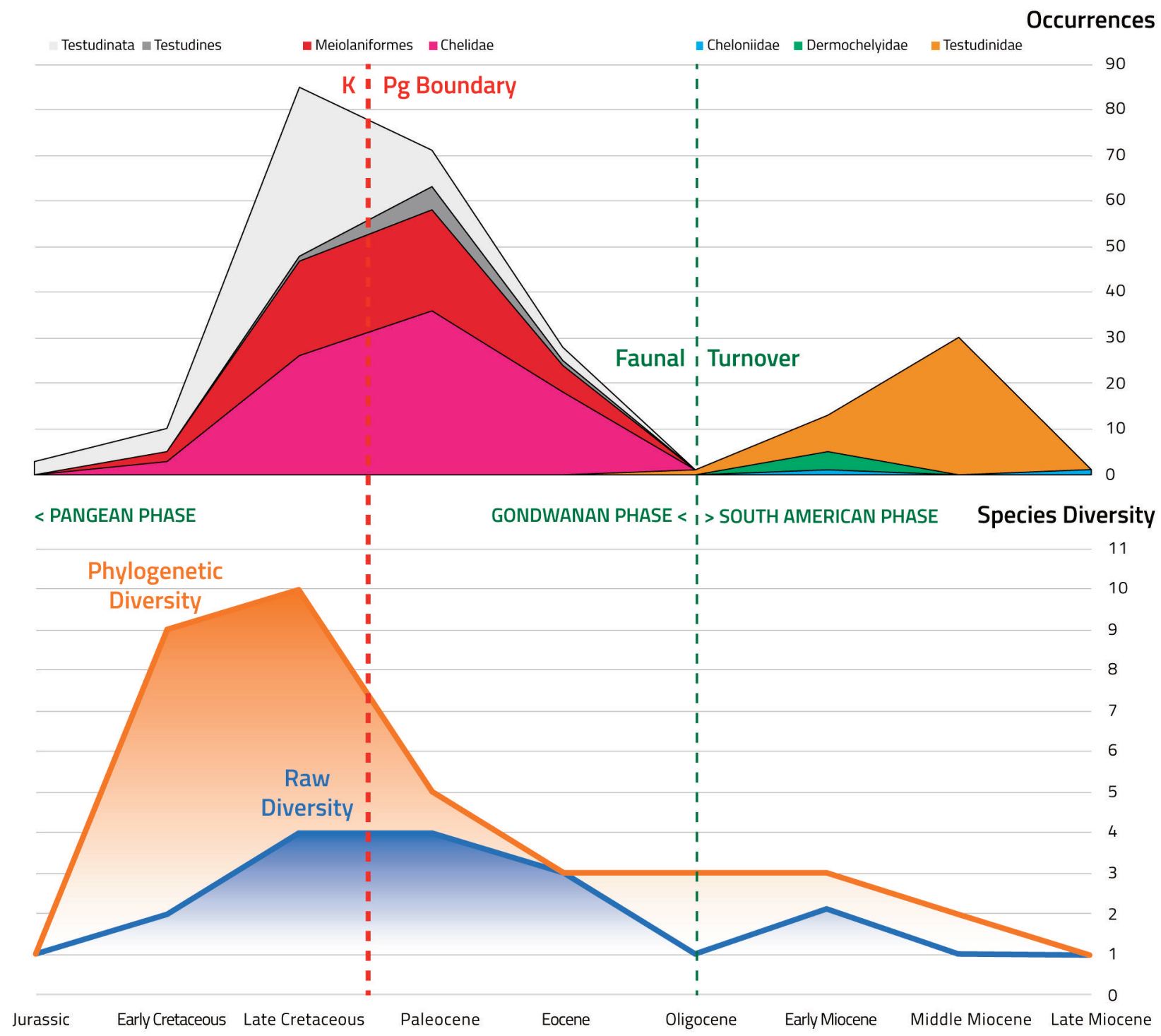

Figure 22. Analyses of occurrence distribution and specific diversity (both raw and phylogenetic) of the turtles of Chubut through time. $\mathbf{K}$, Cretaceous; Pg, Paleogene. 
of the estimated diversity of turtle of this Epoch. On the contrary, in the Paleocene, we already know $80 \%$ of the estimated diversity (four species corresponding to the raw diversity and five species corresponding to the estimated phylogenetic diversity; Fig. 22). The difference between the raw and the phylogenetic diversity is a useful and easyto-calculate proxy for the design of targeted field campaigns to recover this missing diversity (Vlachos et al., 2018).

The transition between the Gondwanan and South American Phases is much more marked and pronounced in Chubut compared to the rest of the continent, with a complete turnover of the turtle faunas. Gondwanan faunal elements (Meiolaniformes, Pan-Chelidae) are recorded until the mid-Eocene, while post-Eocene continental turtles include only the testudinid newcomers (Fig. 22). This turnover in Patagonia is also recognized in the mammalian fauna where substantial taxonomic and ecological changes have occurred. This turnover is named 'Patagonian Hinge' as identified by Goin et al. (2010) and coincides with other turnovers identified around the world like the Grand Coupure in Europe and the Mongolian Remodeling in Asia (Stehlin, 1909; Meng \& McKenna, 1998). The diversity of the continental turtles in Chubut is quite low from the Oligocene onwards with only one named species.

Marine turtles present a different story, mainly because of their cosmopolitan status and underexplored/underexposed marine formations in Chubut. All Chubutean occurrences refer to Modern Marine Phase (sensu Vlachos et al., 2018) and deal with mostly solitary occurrences that are poorly identified. However, at least two clades of marine turtles are identified in the Miocene, a result that helps to raise the total diversity of turtles in Chubut to the late Gondwanan levels with three species/clades (Fig. 22). However, even this diversity was short-lived; the Neogene turtle diversity was quite low in Chubut, compared to other parts of the country.

Nowadays, it seems that turtles are no longer present in Chubut. Marine turtles, apparently, do not reach these latitudes and do not use the coast of Chubut for nesting (see TTWG, 2017 and references therein). Tortoises could be possibly known with some potential occurrences of Chelonoidis chilensis at Peninsula Valdés (see Fritz et al., 2012), but these are sporadic cases and require confirmation. It is, therefore, evident that extant turtle diversity in Chubut is quite low or non-existent, reflecting the significant drop in the turtle diversity from the Paleogene onwards.

\section{Patagonian climate and biomes during the last $200 \mathrm{Ma}$}

During the Mesozoic the Earth was dominated by a Hot House climate with a Cold House period between the end of the Jurassic and the beginning of the Cretaceous (Scotese et al., 1999; Iglesias et al., 2011). The predominant biome developed in Patagonia in the Jurassic was the Subtropical Seasonal Dry biome characterized by the presence of a diverse flora of Dipteridacea ferns, Benettitales and Coniferales (Iglesias et al., 2011). During the Early-Middle Jurassic, the stem turtle, Condorchelys antiqua inhabited the small ponds of today's central area of Chubut.

The beginning of the breakup of Gondwana produced global climatic changes resulting, in turn, in modifications of the biomes. In this regard, a Warm Temperate biome is estimated for Patagonia from the Early Cretaceous until the end of the Eocene (Iglesias et al., 2011). The warm climate continued until the Eocene/Oligocene boundary, including periods with climatic optima: the Early Eocene Climate Optimum and the other the Middle Eocene Climate Optimum, and a Thermal Maximum at the Paleocene/ Eocene boundary (Zachos et al., 2001; Westerhold et al., 2020; and references therein). For Patagonia, temperatures between $14-18^{\circ} \mathrm{C}$ and mean annual precipitations over 2000 mm were estimated (Wilf et al., 2005, 2009; Hinojosa et al., 2010; Krause et al., 2010, 2014). From the Early Cretaceous until the mid-Eocene, chelid and meiolaniform turtles dominated the continental cheloniofauna in today's Chubut Province. Extant chelids are freshwater turtles and the same habit is suggested for their extinct representatives (e.g., Jannello et al., 2016, 2018, 2020; Maniel et al., 2018). Nowadays chelids are distributed in South America and Australasia (TTWG, 2017). In South America, chelid turtles are recorded all along the continent (except Chile) being the southernmost record in Buenos Aires Province $\left(38^{\circ} \mathrm{S}\right)$ with Hydromedusa tectifera (TTWG). The more derived meiolaniforms, the clade Meiolaniidae, are large, terrestrial forms, however, the habits of the basal meiolaniforms are not clear yet. As they do not have extant relatives, 
the paleoecology of this group should be studied compared to extant and extinct analogues. More complete specimens and new studies (e.g., paleohistology, limb proportions) could bring more information about their paleoecology.

At the Eocene/Oligocene boundary, the Drake Passage started opening (Livermore et al., 2005). The aperture of this passage allowed the initiation of the circum Antarctic current, causing a global dropping in the temperatures and an intensification of the drought (Zachos et al., 2001). During the Oligocene-mid-Miocene lapse, the predominant biome in Patagonia was the Cold Temperate forest characterized by conifers and deciduous angiosperms (Iglesias et al., 2011). The Patagonian Andes started raising 23-19 Ma (early Miocene; Ramos \& Ghiglione, 2008) causing aridification/desertification east of the Andes and, consequently, biotic changes such as the instauration of a Proto-Espinal/ Steppe biome towards the late Miocene and the restriction of the Cold Temperate forest at the foot of the Andes (Barreda \& Palazzesi, 2007; Iglesias et al., 2011).

The evolution of the turtle faunas in Chubut could roughly correspond to the above-mentioned large-scale changes, and especially to the expansion of the Gondwanan turtle faunas in the Cretaceous-Eocene during the Warm Temperate Phase and their extinction at the end of the Eocene with the onset of the global drop of temperatures. During that time, chelids and meiolaniids went extinct and there is a considerable gap between their last occurrences and the first occurrences of testudinids in the late Oligocene. As tortoises are cosmopolitan species (excluding Antarctica and Oceania) that inhabit a wide range of environments from dry environments (e.g., Chelonoidis chilensis) to rain forests (e.g., Chelonoidis denticulata) (TTWG 2017), possibly they were able to survive and adapt to the arid conditions of the early Miocene. However, and as humidity is important for egg hatchling in Chelonoidis, the gradual aridification from the early Miocene onwards could have caused the extinction of tortoises in more southern latitudes.

\section{The future of Chubut turtles}

This work presents information based on fossil specimens of turtles collected by many people (see Acknowledg- ments) over a long period of time. We present data that improve our knowledge of the fossil record of turtles in Chubut in many different ways. First, the known fossil record is slightly expanded towards younger stratigraphical levels (e.g., Pan-Cheloniidae indet. in Fig. 23), and many of its gaps are filled or partially filled (e.g., cf. Prochelidella sp. from Cerro Mesa and Huanimán, cf. Hydromedusa sp. Pan de Azúcar, Chelonoidis sp. from Cabeza Blanca). For several taxa, the new specimens described herein help to fill morphological gaps and present new information on their morphological variability (e.g., Hydromedusa casamayorensis, Peligrochelys walshae). For several clades or lineages, their records are expanded both temporally and geographically (e.g., cf. Prochelidella sp., Chelonoidis gringorum). All this information could help to design future strategies and priorities for fossil turtle research in Chubut.

Based on the current stratigraphical column of Chubut Province, it seems unlikely to further expand the known fossil record both upwards and downwards the chronostratigraphic scale. As such, future research should focus on filling the gaps of the known extent of the Chubutean fossil record of turtles, currently spanning from the Early Jurassic (Toarcian) to the late Miocene (Tortonian), via targeted field campaigns and investigations. The longest gap is now identified in the Middle Jurassic (Bajocian)-Lower Cretaceous (Barremian). Closing this gap should be viewed as a top priority, as it would include the first important faunal turnover of the South American turtle fauna, from the Pangean to the Gondwanan Phase (as defined by Vlachos et al., 2018; Fig. 23). The Chubutean record contains important information on the later development of the Pangean turtles, characterized by the presence of small, gracile and aquatic turtles like C. antiqua (Vlachos et al., 2018; Sterli et al., 2019 and references therein). Shortly after the Cañadón Asfalto turtles we should expect the emergence of the Gondwanan turtles, which by the Aptian were already quite diverse in Chubut with several lineages of meiolaniform and chelid turtles. Thus, any fossil occurrence that could help to close this nearly $50 \mathrm{Ma}$ long gap (Fig. 23) would provide important information on the early evolution of turtles in the continent.

The rest of the fossil record of the Gondwanan Faunal Phase is fairly complete and continuous in Chubut, allowing 
Pe APA | Publicación Electrónica - 2021 - Volumen 21(1): 118-160

the description of a diverse and well-known fauna of meiolaniforms and chelids (Fig. 23). Existing gaps in the Albian and Coniacian-Santonian are partly filled with the new occurrences reported herein, leaving a gap in the ConiacianSantonian and another gap in the Selandian-Thanetian
(Fig. 23). In our opinion, future research on the Gondwanan turtle faunas in Chubut should have a different objective compared to the previous one. In this case, efforts should be made to clarify the phylogenetic framework of Meiolaniformes and Pan-Chelidae, via the description of new anatomical el-

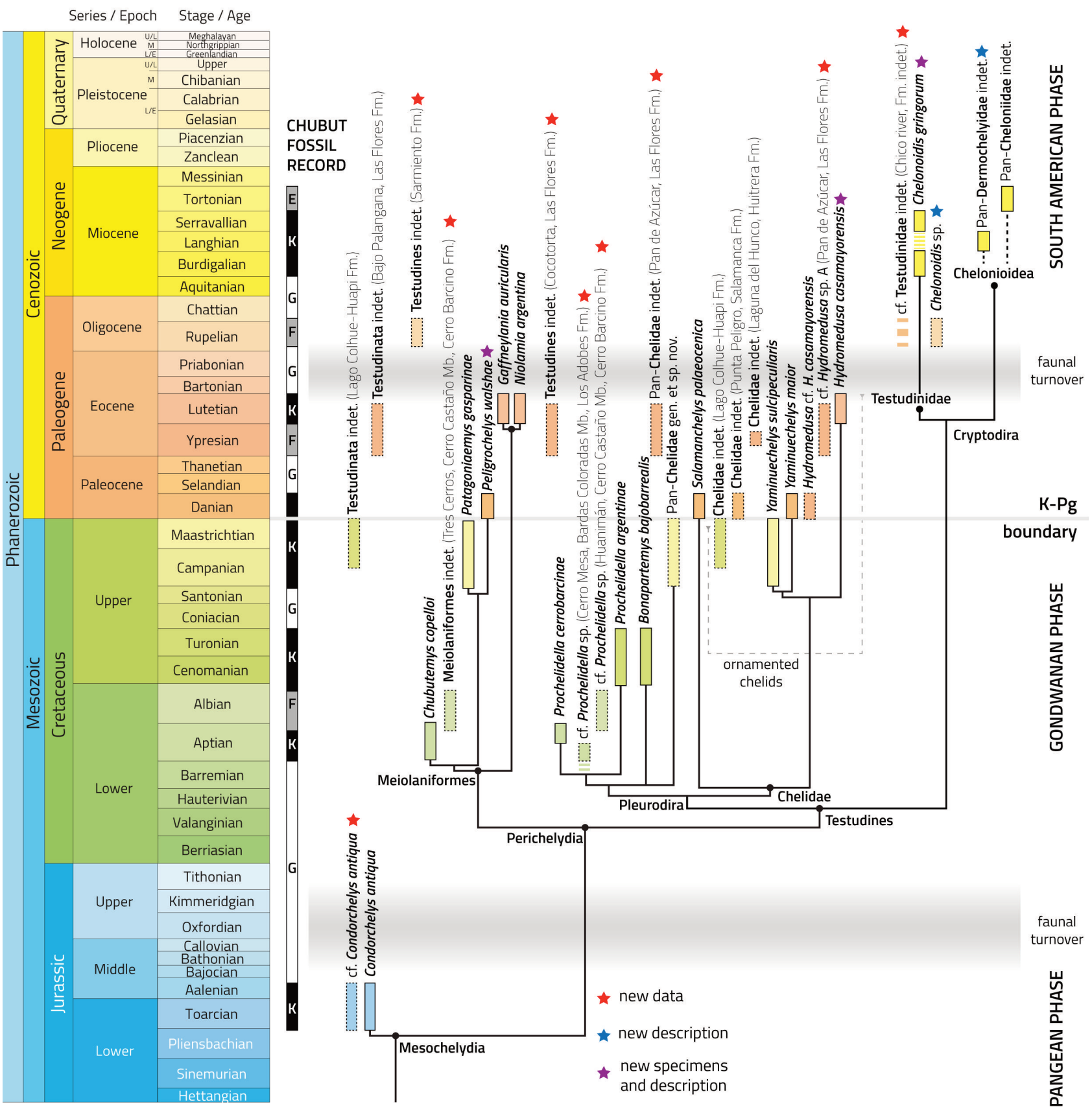

Figure 23. The geochronological distribution of Chubut turtles in a phylogenetic arrangement, showing the two faunal turnovers between the Pangean, Gondwanan, and South American faunal phases and the completion of the fossil record of Chubut. Abbreviations: E, extended fossil record; F, fossil record filled in this work; G, gap in the fossil record; $K$, fossil record known before the present work. 
ements of known taxa combined with the description of new taxa. As far as Meiolaniformes is concerned, we need to clarify the internal relationships of the clade for the nonMeiolaniidae taxa, and especially whether they form a clade sister to the horned turtles (e.g., Sterli \& de la Fuente, 2011) or are placed successively along their stem (e.g., Sterli \& de la Fuente, 2019). Solving these topological problems is fundamental for our interpretation of the changes in diversity in the Late Cretaceous, prior to the K/Pg extinction event that has affected South American and Chubutean turtles.

Future explorations should also target filling the ghost lineages with new occurrences (as it has been done in some cases herein) for some of the most important clades. Regardless of the topological disagreement within Meiolaniformes (mentioned above), we estimate that either older representatives of Meiolaniidae or younger non-meiolaniid-meiolaniforms should have been present in the latest CretaceousPaleocene times, and their occurrences might be found in Chubut. The same is to be expected for more basal meiolaniformes that could be present in chelid-bearing formations in the Cenomanian-Santonian. The chelid record of the Gondwanan Phase is much more complete in Chubut, however, future explorations should should aim to fill the record of ornamented chelids (e.g., Yaminuechelys and Hydromedusa) in the Cretaceous. As also seen herein, their fossils are easily distinguishable from other chelids or meiolaniformes, and even isolated fragments from the shell could provide valuable information.

Despite various sampling efforts in the late EoceneOligocene (e.g., Mustersean, Deseadan SALMAs) focused on the recovery of extinct mammals, the record of extinct turtles is quite scarce in Chubut. This lapse is fundamental for our understanding of the early stages of the South American Phase. Apparently, testudinids were already present in these latitudes by the Oligocene (e.g., Cabeza Blanca locality), and future studies should focus on further refining the oldest occurrences, their geographical distribution, as well as finding a more precise taxonomic identification.

Finally, marine turtles are quite undersampled in Chubut, but recent explorations have brought to light important fossils and occurrences (Viglino et al., in press). This highlights the potential of fossil marine turtles in the Province and could lead to a new line of chelonian research in Argentina.

\section{ACKNOWLEDGMENTS}

This work (and many others) would not have been possible without the selfless help of many people that have collected turtle material since remote times. We are in debt to all of them. The following people are thanked because they collected the specimens described herein, in alphabetical order: S. Bessone, M. Buono, F. Busker, M. Caffa, L. Canessa, J. L. Carballido, M. Cárdenas, L. Chornogubsky, M. A. Cozzuol, J. Cuitiño, M. S. de la Fuente, M. T. Dozo, A. Gandolfo, L. González-Ruiz, F. Laza, I. Maniel, J. P. O'Gorman, K. Panzeri, M. E. Pérez, D. Pol, O. Rauhut, T. Rich, D. Rojas-Lanús, G. W. Rougier, P. Vickers-Rich, M. Viglino, A. Villafañe, M. G. Vucetich, and P. Wilf, as well as many others that have participated in the different fieldworks. We apologize if some names are omitted, but it was not intentional. Besides, we would also like to recognize the labor of many paleontologists that explored Chubut province looking for fossils: J. F. Bonaparte, P. Bondesio, F. von Huene, E. L. Marshall, O. E. Odreman Rivas, R. Pascual, and G. G. Simpson. We would like to thank M. Ezcurra and A. Kramarz (MACN), M. Tanúz (UBA), M. Reguero (MLP), and E. Ruigómez (MEF) because they granted the access to the collections under their care. Many preparators have prepared and cured the specimens presented here and they are thanked as well: A. Aresti, M. Caffa, L. Canessa, N. Pfeiffer, L. Reiner (MEF), S. Bessone (CENPAT), and M. Cárdenas (MACN). We are also grateful to the Secretaría de Cultura de Chubut for authorizing fieldwork in the province and to all the owners that allowed us and other paleontologists to perform paleontological research on their farms. We also deeply thank G. Casal, J. Cuitiño, E. Figari, L. González Ruiz, and R. Scasso for sharing information and discussions on stratigraphy. We also thank I. Maniel and R. Scasso for reviewing this manuscript; their comments improved the quality of this contribution. We would also like to thank the Paleobiology Database community and all the scientists that entered Argentinean turtle occurrence data in the PBDB used herein (E. Vlachos, 59\%, P. Mannion, 9\%, R. Benson, 8\%, M. Carrano, 7\%, J. Tennant, 3\%; H. Street, K. Magoulick, R. Butler, J. Alroy, M. Kouvari, M. Vallejo, P. Holroyd, A. Cardenas, D. Croft, M. Uhen, S. Devincenzi, E. Leckey, J. Wertheim, J. Zijlstra, each less than $1 \%$ ). This study was partially financed by PICTs 2012-0227 (JS), 2013-0095 (M. S. de la Fuente), PICT 20162334 (EV), PICT 2017-1265 (Eduardo Bellosi), PICT 2018-1848 (JS), and NGS 8975-11 (JS).

\section{REFERENCES}

Aberhan, M., Weidemeyer, S., Kiessling, W., Scasso, R. A., \& Medina, F. A. (2007). Faunal evidence for reduced productivity and uncoordinated recovery in Southern Hemisphere CretaceousPaleogene boundary sections. Geology, 35(3), 227-230. https:// doi.org/10.1130/G23197A.1

Albino, A. M. (2000). New record of snakes from the Cretaceous of Patagonia (Argentina). Geodiversitas, 22(2), 247-253.

Allard, J. O., Paredes, J. M., Foix, N., \& Giacosa, R. E. (2015). Conexión cretácica entre las cuencas del Golfo San Jorge y Cañadón Asfalto (Patagonia): paleogeografía, implicancias tectonoestratigráficas y su potencial en la exploración de hidrocarburos. Revista de la Asociación Geológica Argentina, 72(1), 25-41.

Allard, J. O., Paredes, J. M., \& Giacosa, R. E. (2009). Fluvial dynamics, alluvial architecture and palaeohydrology of axial and transverse drainage systems in an extensional setting: Los Adobes Formation (Aptian), Cañadón Asfalto Basin, Argentina. Acta Geológica Lilloana - Suplemento $9^{\circ}$ International Conference on Fluvial Sedimentation, 21, 12-13.

Apesteguía, S., Rougier, G. W., \& Vera, R. (2017). A rhynchocephalian remain from the Late Cretaceous La Colonia Formation (Chubut 
Province, Argentina). Publicación Electrónica de la Asociación Paleontológica Argentina, 18(R2), R7.

Barreda, V. D., Cúneo, N. R., Wilf, P., Currano, E. D., Scasso, R. A., \& Brinkhuis, H. (2012). Cretaceous/Paleogene floral turnover in Patagonia: drop in diversity, low extinction, and a Classopollis spike. PLOS ONE, 7(12), 1-8. https://doi.org/10.1371/journal. pone. 0052455

Barreda, V. D. \& Palazzesi, L. (2007). Patagonian vegetation turnovers during the Paleogene-Early Neogene: origin of arid-adapted floras. The Botanical Review, 73(1), 31-50.

Bellosi, E. S. (2010). Physical stratigraphy of the Sarmiento Formation (middle Eocene-lower Miocene) at Gran Barranca, central Patagonia. In R. H. Madden, A. A. Carlini, M. G. Vucetich, \& R. F. Kay (Eds.), The Paleontology of Gran Barranca: Evolution and Environmental Change through the Middle Cenozoic of Patagonia (pp. 19-31). Cambridge University Press.

Bellosi, E. S. \& Krause, J. M. (2014). Onset of the Middle Eocene global cooling and expansion of open-vegetation habitats in central Patagonia. Andean Geology, 41(1), 29-48.

Bilmes, A., D'Elia, L., Veiga, G. D., \& Franzese, J. R. (2014). Relleno intermontano en el antepaís fragmentado: evolución neógena de la cuenca de Gastre. Revista de La Asociación Geológica Argentina, 71(3), 311-330.

Bona, P. (2006). Paleocene (Danian) chelid turtles from Patagonia, Argentina: Taxonomic and biogeographic implications. Neues Jahrbuch für Geologie und Palaontologie, 241, 303-323.

Bona, P. \& de la Fuente, M. S. (2005). Phylogenetic and paleobiogeographic implications of Yaminuechelys maior (Staesche, 1929) nov. comb., a large long-necked chelid turtle from the Early Paleocene of Patagonia, Argentina. Journal of Vertebrate Paleontology, 25(3), 569-582.

Bonaparte, J. F. (1985). A horned Cretaceous carnosaur from Patagonia. National Geographic Research, 1(1), 149-151.

Bonaparte, J. F., Van Valen, L., \& Kramarz, A. G. (1993). La Fauna Local de Punta Peligro, Paleoceno inferior de la provincia de Chubut, Patagonia, Argentina. Evolutionary Monographs, 14, 1-61.

Bordas, A. (1939). Diagnosis sobre algunos mamíferos de las capas con Colpodon del valle del río Chubut (República Argentina). Physis, 14, 413-446.

Borel, C. M., Guler, M. V., Navarro, E., \& Astini, R. (2016). Ancient Coastal Environments in a Maastrichtian - ?Paleocene Atlantic Shoreline: a Phytoplankton Approach. In M. Martínez and E. Olivera (Eds.), Palinología del Meso-Cenozoico de Argentina - Volumen en homenaje a Mirta Elena Quattrocchio. Publicación Electrónica de la Asociación Paleontológica Argentina, 16(2), 76-87.

Bridge, J. S., Jalfin, G. A., \& Georgieff, S. M. (2000). Geometry, lithofacies, and spatial distribution of cretaceous fluvial sandstone bodies, San Jorge Basin, Argentina: outcrop analog for the hydrocarbon-bearing Chubut Group. Journal of Sedimentary Research, 70(2), 341-359.

Bucher, J., García, M., López, M., Milanese, F., Bilmes, A., D`Elia, L., Naipauer, M., Sato, A. M., Funes, D., Rapalini, A., \& Franzese, J. R. (2019). Tectonostratigraphic evolution and timing deformation in the Miocene Paso del Sapo Basin: Implications for the Patagonian broken foreland. Journal of South American Earth Sciences, 94(102212), 1-13.

Casal, G. A., Allard, J. O., \& Foix, N. (2015). Análisis estratigráfico y paleontológico del Cretácico superior en la cuenca del Golfo San Jorge: nueva unidad litoestratigráfica para el Grupo Chubut. Revista de la Asociación Geológica Argentina, 72(1), 77-95.

Casal, G. A., Martínez, R. D., Luna, M., \& Ibiricu, L. M. (2016). Ordenamiento y caracterización faunística del Cretácico Superior del grupo Chubut, Cuenca del Golfo San Jorge, Argentina. Revista Brasileira de Paleontologia, 19(1), 53-70.

Chebli, G. A., Carlos, N., Sciutto, J. C., \& Serraiotto, A. A. (1976). Estratigrafía del Grupo Chubut en la región central de la provincia homónima. $6^{\circ}$ Congreso Geológico Argentino (pp. 375-392). La Plata.

Clyde, W. C., Krause, J. M., De Benedetti, F., Ramezani, J., Cúneo, N. R., Gandolfo, M. A., Haber, P., Whelan, C., \& Smith, T. (2021). New South American record of the Cretaceous-Paleogene boundary (La Colonia Formation, Patagonia, Argentina). Cretaceous Research. https://doi.org/10.1016/j.cretres.2021.104889

Clyde, W. C., Wilf, P., Iglesias, A., Slingerland, R. L., Barnum, T., Bijl, P. K., Bralower, T. J., Brinkhuis, H., Comer, E. E., Huber, B. T., IbañezMejia, M., Jicha, B. R., Krause, J. M., Schueth, J. D., Singer, B. S., Raigemborn, M. S., Schmitz, M. D., Sluijs, A., \& Zamaloa, M. del C. (2014). New age constraints for the Salamanca Formation and lower Río Chico Group in the western San Jorge Basin, Patagonia, Argentina: Implications for Cretaceous-Paleogene extinction recovery and land mammal age correlations. Bulletin of the Geological Society of America, 126(3-4), 289-306.

Codignotto, J., Nullo, F., Panza, J., \& Proserpio, C. (1978). Estratigrafía del Grupo Chubut entre Paso de Indios y Las Plumas, provincia del Chubut, Argentina. $7^{\circ}$ Congreso Geológico Argentino, 471-480. Neuquén.

Comer, E. E., Slingerland, R. L., Krause, J. M., Iglesias, A., Clyde, W. C., Raigemborn, M. S., \& Wilf, P. (2015). Sedimentary facies and depositional environments of diverse early Paleocene floras, north-central San Jorge Basin, Patagonia, Argentina. Palaios, 30(7), 553-573.

Continanzia, J., Manceda, R., Covellone, G. M., \& Gavarrino, A. S. (2011). Cuencas de Rawson y Valdés: Síntesis del conocimiento exploratorio - Visión Actual. In E. Kozlowski, L. Legarreta, A. Boll, \& P. A. Marshall (Eds.), $7^{\circ}$ Congreso de Exploración y Desarrollo de Hidrocarburos. Simposio Cuencas Argentinas: visión actual (pp. 4764). Instituto Argentino del Petróleo y el Gas.

Cortiñas, J. S. (1996). La cuenca de Somuncurá-Cañadón Asfalto: sus límites, ciclos evolutivos del relleno sedimentario y posibilidades exploratorias. $13^{\circ}$ Congreso Geológico Argentino y $3^{\circ}$ Congreso de Exploración de Hidrocarburos (Actas 1, pp. 147-163). Buenos Aires.

Cuitiño, J. I., Dozo, M. T., del Río, C. J., Buono, M. R., Palazzesi, L., Fuentes, S., \& Scasso, R. A. (2017). Miocene marine transgressions: paleoenvironments and paleobiodiversity. In P. Bouza \& A. Bilmes (Eds.), Late Cenozoic of Península Valdés, Patagonia, Argentina (pp. 47-84). Springer Earth System Sciences.

Cúneo, N. R., Gandolfo, M. A., Zamaloa, M. C., \& Hermsen, E. (2014). Late Cretaceous aquatic plant world in Patagonia, Argentina. Plos One, 9(8), e104749.

Cúneo, N. R., Hermsen, E. J., \& Gandolfo, M. A. (2013b). Regnellidium (Aalviniales, Marsileaceae) macrofossils and associated spores from the Late Cretaceous of South America. International Journal of Plant Sciences, 174(3), 340-349.

Cúneo, N. R., Ramezani, J., Scasso, R., Pol, D., Escapa, I., Zavattieri, A. M., \& Bowring, S. A. (2013a). High-precision U-Pb geochronology and a new chronostratigraphy for the Cañadón Asfalto Basin, Chubut, central Patagonia: Implications for terrestrial faunal and floral evolution in Jurassic. Gondwana Research, 24(3-4), 12671275.

de Broin, F. D. L. \& de la Fuente, M. S. (1993). Les tortues fossiles d'Argentine: synthèse. Annales de Paléontologie, 79,169-232.

de Broin, F. D. L. \& de la Fuente, M. S. (2001). Oldest world Chelidae (Chelonii, Pleurodira), from the Cretaceous of Patagonia, Argentina. Comptes Rendus de I'Académie des Sciences-Series IIA-Earth 
and Planetary Science, 333(8), 463-470.

de la Fuente, M. S. (1994). Descripción de nuevos especímenes y relaciones filogenéticas de Chelonoidis gringorum (Simpson, 1942) (Chelonii: Testudinidae) del Mioceno temprano de Patagonia Central, Argentina. Stvdia Geologica Salmanticensia, 30, 107-131.

de la Fuente, M. S. (1997). Las tortugas terrestres gigantes (Chelonii: Testudinidae) del Mioceno Tardío-Plioceno del territorio argentino. Studia Geologica Salmanticensia, 33, 91-120.

de la Fuente, M. S. \& Bona, P. (2002). Una nueva especie del género Hydromedusa Wagler (Pleurodira, Chelidae) del Paleógeno de Patagonia. Ameghiniana, 39(1), 77-83.

de la Fuente, M. S., Umazano, A. M., Sterli, J., \& Carballido, J. L. (2011). New chelid turtles of the lower section of the Cerro Barcino formation (Aptian-Albian?), Patagonia, Argentina. Cretaceous Research, 32(4), 527-537.

de la Fuente, M. S. \& Vucetich, M. G. (1998). Nuevos materiales de tortugas cryptodiras miocenas del valle del Chubut, Argentina. Ameghiniana, 35(2), 211-215.

de la Fuente, M. S., Zacarías, G. G., \& Vlachos, E. (2018). A review of the fossil record of South American turtles of the clade Testudinoidea. Bulletin of the Peabody Museum of Natural History, 59(2), 269-286.

del Río, C. J., Martínez, S. A., McArthur, J. M., Thirlwall, M. F., \& Pérez, L. M. (2018). Dating late Miocene marine incursions across Argentina and Uruguay with Sr-isotope stratigraphy. Journal of South American Earth Sciences, 85, 312-324.

del Río, C. J., Martínez, S. A., \& Scasso, R. A. (2001). Nature and origin of spectacular marine miocene shell beds of Northeastern Patagonia (Argentina): Paleoecological and bathymetric significance. Palaios, 16(1), 3-25. https://doi.org/10.1669/08831351(2001)016<0003:NAOOSM>2.0.CO;2

Dozo, M. T., Bouza, P., Monti, A., Palazzesi, L., Barreda, V., Massaferro, G., Scasso, R. A., \& Tambussi, C. P. (2010). Late Miocene continental biota in Northeastern Patagonia (Península Valdés, Chubut, Argentina). Palaeogeography, Palaeoclimatology, Palaeoecology, 297(1), 100-109. https://doi.org/10.1016/j.palaeo.2010.07.018

Dozo, M. T., Ciancio, M., Bouza, P., \& Martínez, G. (2014). Nueva asociación de mamíferos del Paleógeno en el este de la Patagonia (provincia de Chubut, Argentina): Implicancias biocronológicas y paleobiogeográficas. Andean Geology, 41(1), 224-247.

Dunn, R. E., Madden, R. H., Kohn, M. J., Schmitz, M. D., Strömberg, C. A. E., Carlini, A. A., Ré, G. H., \& Crowley, J. (2013). A new chronology for middle Eocene-early Miocene South American Land Mammal Ages. GSA Bulletin, 125(3-4), 539-555.

Fantasia, A., Föllmi, K. B., Adatte, T., Spangenberg, J. E., Schoene, B., Barker, R. T., \& Scasso, R. A. (2021). Late Toarcian continental palaeoenvironmental conditions: An example from the Cañadón Asfalto Formation in southern Argentina. Gondwana Research, 89, 47-65. https://doi.org/10.1016/j.gr.2020.10.001

Feruglio, E. (1949). Descripción geológica de la Patagonia 2. Dirección general de yacimientos petrolíferos fiscales. Coni Press.

Figari, E. G., Scasso, R. A., Cúneo, R. N., \& Escapa, I. (2015). Estratigrafía y evolución geológica de la Cuenca de Cañadón Asfalto, provincia del Chubut, Argentina. Latin American Journal of Sedimentology and Basin Analysis, 22(2), 135-169.

Figari, E. G., Strelkov, E., Laffitte, G., Cid de la Paz, M. S., Courtade, S. F., Celaya, J., Vottero, A., Lafourcade, P., Martínez, R., \& Villar, H. J. (1999). Los sistemas petroleros de la cuenca del Golfo San Jorge: sintesis estructural, estratigráfica y geoquímica. $4^{\circ}$ Congreso de Exploración y Desarrollo de Hidrocarburos, (Actas 1, pp. 197-237). Mar del Plata.

Fitzgerald, M. G., Mitchum, R. M., Uliana, M. A., \& Biddle, K. T. (1990).
Evolution of the San Jorge Basin, Argentina. American Association of Petroleum Geologists Bulletin, 74, 879-920. https://doi.org/ 10.1306/0c9b23c1-1710-11d7-8645000102c1865d

Fleagle, J. G. \& Bown, T. M. (1983). New primate fossils from late Oligocene (Colhuehuapian) localities of Chubut Province, Argentina. Folia Primatologica, 41(3-4), 240-266.

Fritz, U., Alcalde, L., Vargas-Ramírez, M., Goode, E. V., Fabius-Turoblin, D. U., \& Praschag, P. (2012). Northern genetic richness and southern purity, but just one species in the Chelonoidis chilensis complex. Zoologica Scripta, 41(3), 220-232.

Gaffney, E. S. (1996). The postcranial morphology of Meiolania platyceps and a review of the Meiolaniidae. Bulletin of the American Museum of Natural History, 229, 1-166.

Gaffney, E. S., Rich, T. H., Vickers-Rich, P., Constantine, A., Vacca, R., \& Kool, L. (2007). Chubutemys, a new eucryptodiran turtle from the Early Cretaceous of Argentina, and the relationships of the Meiolaniidae. American Museum Novitates, 2007, 1-35.

Gasparini, Z. \& de la Fuente, M. S. (2000). Tortugas y plesiosaurios de la Formación La Colonia (Cretácico Superior) de Patagonia. Revista Española de Paleontología, 15(1), 23-35.

Gasparini, Z., Sterli, J., Parras, A., O'Gorman, J. P., Salgado, L., Varela, J., \& Pol, D. (2015). Late Cretaceous reptilian biota of the La Colonia Formation, central Patagonia, Argentina: Occurrences, preservation and paleoenvironments. Cretaceous Research, 54, $154-168$.

Goin, F. J., Abello, M. A., \& Chornogubsky, L. (2010). Middle Tertiary marsupials from central Patagonia (early Oligocene of Gran Barranca): understanding South America's Grande Coupure. In R. H. Madden, A. A. Carlini, M. G. Vucetich, \& R. F. Kay (Eds.), The paleontology of Gran Barranca: evolution and environmental change through the Middle Cenozoic of Patagonia (pp. 69-105). Cambridge University Press.

Gosses, J., Carroll, A. R., Bruck, B. T., Singer, B. S., Jicha, B. R., Aragón, E., Walters, A. P., \& Wilf, P. (2020). Facies interpretation and geochronology of diverse Eocene floras and faunas, northwest Chubut Province, Patagonia, Argentina. GSA Bulletin, 1-13.

Guler, M. V., Borel, C. M., Brinkhuis, H., Navarro, E., \& Astini, R. (2014). Brackish to Freshwater Dinoflagellate Cyst Assemblages from the la Colonia Formation (Paleocene?), Northeastern Patagonia, Argentina. Ameghiniana, 51(2), 141-153.

Guler, M. V., González Estebenet, M. S., Navarro, E. L., Astini, R. A., Pérez Panera, J. P., Ottone, E. G., Pieroni, D., \& Paolillo, M. A. (2019). Maastrichtian to Danian Atlantic transgression in the north of Patagonia: A dinoflagellate cyst approach. Journal of South American Earth Sciences, 92, 552-564.

Hinojosa, L. F., Pérez, F., Gaxiola, A., \& Sandoval, I. (2010). Historical and phylogenetic constraints on the incidence of entire leaf margins: insights from a new South American model. Global Ecology and Biogeography, 20(3), 380-390.

Huene von, F. V. (1928). Die fossilen Reptilien des südamerikanischen Gondwanalandes. Ergebnisse der Sauriergrabungen in Südbrasilien, 29(1), 1-332.

Iglesias, A., Artabe, A. E., \& Morel, E. M. (2011). The evolution of Patagonian climate and vegetation from the Mesozoic to the present. Biological Journal of the Linnean Society, 103(2), 409422.

Jannello, J. M., Cerda, I. A., \& de la Fuente, M. S. (2016). Shell bone histology of the long-necked chelid Yaminuechelys (Testudines: Pleurodira) from the late Cretaceous-early Palaeocene of Patagonia with comments on the histogenesis of bone ornamentation. The Science of Nature, 103(3-4), 1-26.

Jannello, J. M., Cerda, I. A., \& de la Fuente, M. S. (2020). The relation- 
ship between bone shell microanatomy and palaeoecology in Testudinata from South America. Palaeogeography, Palaeoclimatology, Palaeoecology, 537(109412), 1-9.

Jannello, J. M., Maniel, I. J., Previtera, E., \& de la Fuente, M. S. (2018). Linderochelys rinconensis (Testudines: Pan-Chelidae) from the Upper Cretaceous of northern Patagonia: New insights from shell bone histology, morphology and diagenetic implications. Cretaceous Research, 83, 47-61.

Joyce, W. G., Sterli, J., \& Chapman, S. D. (2014). The skeletal morphology of the solemydid turtle Naomichelys speciosa from the Early Cretaceous of Texas. Journal of Paleontology, 88(6), 12571287.

Kay, R. F., Fleagle, J. G., Mitchell, T. R. T., Colbert, M., Bown, T., \& Powers, D. W. (2008). The anatomy of Dolichocebus gaimanensis, a stem platyrrhine monkey from Argentina. Journal of Human Evolution, 54, 323-382.

Kielan-Jaworowska, Z., Ortiz-Jaureguizar, E., Vieytes, C., Pascual, R., \& Goin, F. J. (2007). First ?cimolodontan multituberculate mammal from South America. Acta Palaeontologica Polonica, 52(2), 257-262.

Krause, J. M., Bellosi, E. S., \& Raigemborn, M. S. (2010). Lateritized tephric palaeosols from Central Patagonia, Argentina: a southern high-latitude archive of Palaeogene global greenhouse conditions. Sedimentology, 57(7), 1721-1749.

Krause, J. M., Clyde, W. C., Ibañez-Mejía, M., Schmitz, M. D., Barnum, T., Bellosi, E. S., \& Wilf, P. (2017). New age constraints for early Paleogene strata of central Patagonia, Argentina: Implications for the timing of South American Land Mammal Ages. Bulletin of the Geological Society of America, 129(7-8), 886-903.

Krause, J. M. \& Piña, C. I. (2012). Reptilian coprolites in the Eocene of central Patagonia, Argentina. Journal of Paleontology, 86(3), 527538.

Krause, J. M., Ramezani, J., Umazano, A. M., Pol, D., Carballido, J. L., Sterli, J., \& Bellosi, E. S. (2020). High-resolution chronostratigraphy of the Cerro Barcino Formation (Patagonia): Paleobiologic implications for the mid-cretaceous dinosaur-rich fauna of South America. Gondwana Research, 80, 33-49.

Krause, J. M., Umazano, A. M., Bellosi, E. S., \& White, T. S. (2014). Hydromorphic paleosols in the upper Puesto La Paloma Member, Cerro Barcino Formation, mid Cretaceous, Patagonia Argentina: environmental and stratigraphic significance. $14^{\circ}$ Reunión Argentina de Sedimentología (pp. 146-147). Puerto Madryn.

Lawver, D. R., Debee, A. M., Clarke, J. A., \& Rougier, G. W. (2011). A new enantiornithine bird from the Upper Cretaceous La Colonia Formation of Patagonia, Argentina. Annals of Carnegie Museum, $80(1), 35-42$.

Legarreta, L. \& Uliana, M. A. (1994). Asociaciones de fósiles y hiatos en el supracretácico-Neógeno de Patagonia: una perspectiva estratigráfico-secuencial. Ameghiniana, 31(3), 257-281.

Livermore, R., Nankivell, A., Eagles, G., \& Morris, P. (2005). Paleogene opening of Drake passage. Earth and Planetary Science Letters, 236, 459-470.

Maniel, I. J. \& de la Fuente, M. S. (2016). A review of the fossil record of turtles of the clade Pan-Chelidae. Bulletin of the Peabody Museum of Natural History, 57(2), 191-227.

Maniel, I. J., de la Fuente, M. S., Sterli, J., Jannello, J. M., \& Krause, J. M. (2018). New remains of the aquatic turtle Hydromedusa casamayorensis (Pleurodira, Chelidae) from the middle Eocene of Patagonia: taxonomic validation and phylogenetic relationships. Palaeontology, 4(4), 537-566.

Marshall, L. G. (1985). Geochronology and Land-mammal biochronology of the Transamerican Faunal Interchange. In Stehli, F. \& Webb, S. D.
(Eds.), The Great America Biotic Interchange (pp. 49-85). Plenum Press.

Marshall, L. G., Cifelli, R. L., Drake, R. E., \& Curtis, G. H. (1986). Vertebrate paleontology, geology, and geochronology of the Tapera de Lopez and Scarritt Pocket, Chubut Province, Argentina. Journal of Paleontology, 60(4), 920-951.

Marveggio, N. \& Llorens, M. (2013). Nueva edad de la base del Grupo Chubut en la mena uranífera Cerro Solo, Provincia Del Chubut. Revista de la Asociación Geológica Argentina, 70(3), 318-326.

Meng, J. \& McKenna, M. C. (1998). Faunal turnovers of Palaeogene mammals from the Mongolian Plateau. Nature, 394, 364-367.

Musacchio, E. A. (1995). Estratigrafía y micropaleontología del Jurásico y el Cretácico en la comarca del valle medio del río Chubut, Argentina. $6^{\circ}$ Congreso Argentino de Paleontología y Bioestratigrafía (pp. 179-187). Trelew.

Navarro, L. E., Borel, C. M., Guler, V., \& Astini, R. A. (2008). Anatomía y facies asociadas a una superficie transgresiva en un mar epicontinental patagónico, Formación La Colonia, Telsen, Chubut. $12^{\circ}$ Reunión Argentina de Sedimentología (pp. 126). Buenos Aires.

Navarro, L. E., Borel, C. M., Guler, V., \& Astini, R. A. (2012). Análisis de facies y ambientes depositacionales de la Formación La Colonia en el área de Telsen, Chubut, Patagonia. $13^{\circ}$ Reunión Argentina de Sedimentología (pp. 153-154). Salta.

Oriozabala, C., Sterli, J., \& de la Fuente, M. S. (2020). New species of the long-necked chelid Yaminuechelys from the Upper Cretaceous (Campanian-Maastrichtian) of Chubut, Argentina. Cretaceous Research, 106(104197), 1-11.

Oriozabala, C., Sterli, J., \& Ruiz, L. G. (2018). Morphology of the midSized Tortoises (Testudines: Testudinidae) from the Middle Miocene of Northwestern Chubut (Argentina). Ameghiniana, 55(1), 30-54.

Paredes, J. M., Foix, N., \& Allard, J. O. (2016). Sedimentology and alluvial architecture of the Bajo Barreal Formation (Upper Cretaceous) in the Golfo San Jorge Basin: outcrop analogues of the richest oil-bearing fluvial succession in Argentina. Marine and Petroleum Geology, 72, 317-335.

Pascual, R., Archer, M., Ortiz-Jaureguizar, E., Prado, J. L., Godthelp, H., \& Hand, S. J. (1992). First discovery of monotremes in South America. Nature, 356, 704-706.

Pascual, R., Goin, F. J., González, P., Ardolino, A., \& Puerta, P. (2000). A highly derived docodont from the Patagonian Late Cretaceous: evolutionary implications for Gondwanan mammals. Geodiversitas, 22(3), 395-414.

Proserpio, C. A. (1987). Descripción geológica de la Hoja 44e, Valle General Racedo, Pcia. del Chubut. Dirección Nacional de Minería y Geología, Boletín 201.

Raigemborn, M. S., Krause, J. M., Bellosi, E., \& Matheos, S. D. (2010). Redefinición estratigráfica del Grupo Río Chico (Paleógeno inferior), en el norte de la cuenca del Golfo San Jorge, Chubut. Revista de La Asociación Geológica Argentina, 67(2), 239-256.

Ramos, V. A. \& Ghiglione, M. C. (2008). Tectonic evolution of the Patagonian Andes. Developments in Quaternary Sciences, 11, 57-71.

Rauhut, O. W. M., Martin, T., Ortiz-Jaureguizar, E., \& Puerta, P. (2002). A Jurassic mammal from South America. Nature, 416(6877), 165-168.

Ré, G. H., Bellosi, E. S., Heizler, M., Vilas, J. F., Madden, R. H., Carlini, A. A., Kay, R. F., \& Vucetich, M. G. (2010). A geochronology for the Sarmiento Formation at Gran Barranca. In R. H. Madden, A. A. Carlini, M. G. Vucetich, \& R. F. Kay (Eds.), The Paleontology of Gran Barranca: Evolution and Environmental Change through the Middle Cenozoic of Patagonia (pp. 46-59). Cambridge University 
Press.

Riccardi, A. C. (1988). The Cretaceous system of southern South America. The Geological Society of America Memoir (Vol. 168). The Geological Society of America, Inc. https://doi.org/https://doi.org/ 10.1130/MEM168

Roth, S. (1899). Aviso preliminar sobre mamíferos mesozoicos encontrados en Patagonia. Revista del Museo de La Plata, 9, 381-388.

Rougier, G. W., Forasiepi, A. M., Hill, R. V., \& Novacek, M. (2009). New mammalian remains from the Late Cretaceous La Colonia Formation, Patagonia, Argentina. Acta Palaeontologica Polonica, 54(2), 195-212.

Scasso, R. A., Aberhan, M., Ruiz, L., Weidemeyer, S., Medina, F. A., \& Kiessling, W. (2012a). Integrated bio- and lithofacies analysis of coarse-grained, tide-dominated deltaic environments across the Cretaceous/Paleogene boundary in Patagonia, Argentina. Cretaceous Research, 36, 37-57.

Scasso, R. A., \& Bellosi, E. S. (2004). Bryn Gwyn Guidebook. First International Congress on Ichnology, 1-18.

Scasso, R. A. \& Castro, L. N. (1999). Cenozoic phosphatic deposits in North Patagonia, Argentina: Phosphogenesis, sequence-stratigraphy and paleoceanography. Journal of South American Earth Sciences, 12(5), 471-487. https://doi.org/10.1016/S08959811(99)00035-8

Scasso, R. A. \& Cuitiño, J. I. (2017). Sequential development of tidal ravinement surfaces in macro- to hypertidal estuaries with high volcaniclastic input: the Miocene Puerto Madryn Formation (Patagonia, Argentina). Geo-Marine Letters, 37(4), 427-440. https://doi.org/10.1007/s00367-016-0481-3

Scasso, R. A., Cuitiño, J. I., \& Escapa, I. (2010). Mesozoic-Cenozoic basins of Central Patagonia with emphasis in their tidal systems. In C. del Papa \& R. Astini (Eds.), $18^{\circ}$ International Sedimentological Congress. Field Excursion Guidebook (Issue FE-C9, pp. 1-43).

Scasso, R. A. \& del Río, C. (1987). Ambientes de sedimentación, estratigrafía y proveniencia de la secuencia marina del Terciario superior de la región de Península Valdés, Chubut. Revista de la Asociación Geológica Argentina, 62(3-4), 291-321.

Scasso, R. A., Dozo, M. T., Cuitiño, J. I., \& Bouza, P. (2012b). Meandering tidal-fluvial channels and lag concentration of terrestrial vertebrates in the fluvialtidal transition of an ancient estuary in Patagonia. Latin American Journal of Sedimentology and Basin Analysis, 19(1), 27-45.

Scasso, R. A., McArthur, J. M., del Río, C. J., Martínez, S., \& Thirlwall, M. F. (2001). 87Sr/86Sr late miocene age of fossil molluscs in the "entrerriense" of the Valdés Peninsula (Chubut, Argentina). Journal of South American Earth Sciences, 14(3), 319-329. https://doi.org/10.1016/S0895-9811(01)00032-3

Scillato-Yané, G. J. (1977). Sur quelques Glyptodontidae nouveaux (Mammalia, Edentata) du Déséadien (Oligocène inférieur) de Patagonie (Argentine). Bulletin Du Muséum National D'Histoire Naturelle, 64, 249-262.

Scillato-Yané, G. J. \& Pascual, R. (1985). Un peculiar Xenarthra del Paleoceno de Patagonia (Argentina). Su importancia en la sistemática de los Paratheria. Ameghiniana, 21(1-2), 173-176.

Sciutto, J. C. (1981). Geología del codo del río Senguerr, Chubut, Argentina. $8^{\circ}$ Congreso Geológico Argentino (pp. 203-219). Buenos Aires.

Scotese, C. R., Boucot, A. J., \& McKerrow, M. S. (1999). Gondwanan palaeogeography and palaeoclimatology. Journal of African Earth Sciences, 28(1), 99-114.

Simpson, G. G. (1935a). Occurence and relationships of the Río Chico fauna of Patagonia. American Museum Novitates, 818, 1-21.

Simpson, G. G. (1935b). Early and Middle Tertiary geology of the
Gaiman region, Chubut, Argentina. American Museum Novitates, $775,1-29$.

Simpson, G. G. (1937). New reptiles from the Eocene of South America. American Museum Novitates, 927, 1-3.

Simpson, G. G. (1938). Crossochelys, Eocene horned turtle from Patagonia. Bulletin of the American Museum of Natural History, 74(5), 221-225.

Simpson, G. G. (1942). A Miocene tortoise from Patagonia. American Museum Novitates, 1209, 1-6.

Staesche, K. (1929). Schildkrötenreste aus der oberen Kreide Patagoniens. Palaeontographica, 72, 103-112.

Stehlin, H. G. (1909). Remarques sur les faunules de mammifères des couches Eocenes et Oligocenes du Bassin de Paris. Bulletin de la Société Géologique de France, 9, 488-520.

Sterli, J. (2008). A new, nearly complete stem turtle from the Jurassic of South America with implications for turtle evolution. Biology Letters, 4(3), 286-289.

Sterli, J. (2015). A review of the fossil record of Gondwanan turtles of the clade Meiolaniformes. Bulletin of the Peabody Museum of Natural History, 56(1), 21-45.

Sterli, J. \& de la Fuente, M. S. (2011). A new turtle from the La Colonia Formation (Campanian-Maastrichtian), Patagonia, Argentina, with remarks on the evolution of the vertebral column in turtles. Palaeontology, 54(1), 63-78.

Sterli, J. \& de la Fuente, M. S. (2013). New evidence from the Palaeocene of Patagonia (Argentina) on the evolution and palaeo-biogeography of Meiolaniformes (Testudinata, new taxon name). Journal of Systematic Palaeontology, 11(7), 835-852.

Sterli, J. \& de la Fuente, M. S. (2019). Cranial and post-cranial remains and phylogenetic relationships of the Gondwanan meiolaniform turtle Peligrochelys walshae from the Paleocene of Chubut, Argentina. Journal of Paleontology, 93(4), 798-821.

Sterli, J., de la Fuente, M. S., \& Cerda, I. A. (2013). A new species of meiolaniform turtle and a revision of the Late Cretaceous Meiolaniformes of South America. Ameghiniana, 50(2), 240-256.

Sterli, J., de La Fuente, M. S., \& Rougier, G. W. (2019). New remains of Condorchelys antiqua (Testudinata) from the Early-Middle Jurassic of Patagonia: anatomy, phylogeny, and paedomorphosis in the early evolution of turtles. Journal of Vertebrate Paleontology, 38(4), 1-17.

Sterli, J., de la Fuente, M. S., \& Umazano, A. M. (2015). New remains and new insights on the Gondwanan meiolaniform turtle Chubutemys copelloi from the Lower Cretaceous of Patagonia, Argentina. Gondwana Research, 27(3), 978-994.

Sterli, J., Parras, A., Albino, A., Becerra, M. G., Carballido, J. L., GouiricCavalli, S., Muzzopappa, P., Oriozabala, C., Panzeri, K. M., Pérez Moreno, A., Pol, D., Rougier, G. W., \& Salgado, L. (in press). Vertebrados continentales de la Formación La Colonia (CampanianoMaastrichtiano), Chubut, Argentina. In Giacosa, R., Geología y los Recursos Naturales de la provincia del Chubut, Relatorio del $21^{\circ}$ Congreso Geológico Argentino. Revista Asociación Geológica Argentina.

[TTWG] Turtle Taxonomy Working Group (2017) Turtles of the World: Annotated Checklist and Atlas of Taxonomy, Synonymy, Distribution, and Conservation Status (8th Ed.). Chelonian Research Monographs, 7, 1-292.

Uliana, M. A. \& Biddle, K. T. (1988). Mesozoic-Cenozoic Paleogeographic and Geodynamic Evolution of Southern South America. Revista Brasileira de Geociências, 18(2), 172-190.

Umazano, A. M., Bellosi, E. S., Visconti, G., \& Melchor, R. N. (2008). Mechanisms of aggradation in fluvial systems influenced by 
explosive volcanism: An example from the Upper Cretaceous Bajo Barreal Formation, San Jorge Basin, Argentina. Sedimentary Geology, 203(3-4), 213-228.

Umazano, A. M., Krause, J. M., Bellosi, E. S., Pérez, M., Visconti, G., \& Melchor, R. N. (2017). Changing fluvial styles in volcaniclastic successions: A cretaceous example from the Cerro Barcino Formation, Patagonia. Journal of South American Earth Sciences, 77, 185-205.

Vallati, P., De Sosa Tomas, A., \& Casal, G. (2020). A Maastrichtian terrestrial palaeoenvironment close to the $\mathrm{K} / \mathrm{Pg}$ boundary in the Golfo San Jorge basin, Patagonia, Argentina. Journal of South American Earth Sciences, 97, 102401.

Vellekoop, J., Holwerda, F., Prámparo, M. B., Willmott, V., Schouten, S., Cúneo, N. R., Scasso, R. A., \& Brinkhuis, H. (2017). Climate and sea-level changes across a shallow marine Cretaceous-Palaeogene boundary succession in Patagonia, Argentina. Palaeontology, 60(4), 519-534. https://doi.org/10.1111/pala.12297

Viglino, M., Buono, M. R., Acosta Hospitaleche, C., Cione, A., Cuitiño, J. I., Gaetán, M., Sterli, J., \& Paolucci, F. (in press). Vertebrados marinos del Cenozoico de Chubut. In Giacosa, R., Geología y los Recursos Naturales de la provincia del Chubut, Relatorio del $21^{\circ}$ Congreso Geológico Argentino. Revista Asociación Geológica Argentina.

Villegas, P. M. (2015). Respuestas sedimentarias de un sistema fluvial al influjo de sedimentos piroclásticos: el caso de los miembros Bardas Coloradas y Puesto La Paloma durante el Cretácico de Patagonia. [Tesis de grado, Facultad de Ciencias Exactas y Naturales, Universidad Nacional de La Pampa]. From https://repo.unlpam.edu.ar/ bitstream/handle/unlpam/2276/x_vilres899_c.pdf?sequence $=1$ \&isAllowed $=y$

Villegas, P. M., Visconti, G., \& Umazano, A. M. (2014). Respuestas sedimentarias de un sistema fluvial al influjo de sedimentos piroclásticos: el caso de los miembros Bardas Coloradas y Puesto La Paloma durante el Cretácico de Patagonia. $14^{\circ}$ Reunión Argentina de Sedimentología (pp. 295-296). Puerto Madryn.

Vlachos, E., Randolfe, E., Sterli, J., \& Leardi, J. M. (2018). Changes in the diversity of turtles (Testudinata) in South America from the Late Triassic to the present. Ameghiniana, 55(6), 619-643.

Walker, W. F. Jr. 1973. The locomotor apparatus of Testudines. In C. Gans and T. S. Parsons (Eds.), Biology of the Reptilia. Volume 4. Korphology D (pp. 1-100). Academic Press.
Westerhold, T., Marwan, N., Drury, A. J., Liebrand, D., Agnini, C., Anagnostou, E., Barnet, J. S. K., Bohaty, S. M., De Vleeschouwer, D., Florindo, F., Frederichs, T., Hodell, D. A., Holbourn, A. E., Kroon, D., Lauretano, V., Littler, K., Lourens, L. J., Lyle, M., Pälike, H., Röhl, U., Tian J., Wilkens R. H., Wilson P. A., \& Zachos J. C. (2020). An astronomically dated record of Earth's climate and its predictability over the last 66 Million Years. Science, 369, 1383-1387.

Wilf, P., Johnson, K. R., Cúneo, R., Smith, E., Singer, B. S., \& Gandolfo, M. A. (2005). Eocene plant diversity at Laguna del Hunco and Río Pichileufú, Patagonia, Argentina. The American Naturalist, 165, 634-650.

Wilf, P., Little, S. A., Iglesias, A., Zamaloa, M. C., Gandolfo, M. A., Cúneo, N. R., \& Johnson, K. R. (2009). Papuacedrus (Cupressaceae) in Eocene Patagonia: a new fossil link to Australasian rainforests. American Journal of Botany, 96(11), 2031-2047.

Woodburne, M. O., Goin, F. J., Raigemborn, M. S., Heizler, M., Gelfo, J. N., \& Oliveira, E. V. (2014). Revised timing of the South American early Paleogene land mammal ages. Journal of South American Earth Sciences, 54, 109-119.

Zachos, J. C., Pagani, M., Sloan, L., Thomas, E., \& Billups, K. (2001). Trends, rhythms, and aberrations in global climate $65 \mathrm{Ma}$ to present. Science, 292, 686-693.

Editorial Note: Both this work and the nomenclatural acts it contains have been registered in the ZooBank. The work is permanently archived in the Internet Archive.

LSID urn:Isid:zoobank.org:pub:6F28C1BC-5CC2-4AA5-B641-68E76AC930F1

doi: 10.5710/PEAPA.26.02.2021.338

Acceso Abierto Open Access

Recibido: 16 de septiembre 2020

Aceptado: 26 de febrero 2021

Publicado: 25 de junio 2021 